\title{
Evaluation of weaning regimen and seminal plasma biology on reproductive management in cattle
}

\author{
John Fredrick Odhiambo \\ West Virginia University
}

Follow this and additional works at: https://researchrepository.wvu.edu/etd

\section{Recommended Citation}

Odhiambo, John Fredrick, "Evaluation of weaning regimen and seminal plasma biology on reproductive management in cattle" (2008). Graduate Theses, Dissertations, and Problem Reports. 2724.

https://researchrepository.wvu.edu/etd/2724

This Dissertation is protected by copyright and/or related rights. It has been brought to you by the The Research Repository @ WVU with permission from the rights-holder(s). You are free to use this Dissertation in any way that is permitted by the copyright and related rights legislation that applies to your use. For other uses you must obtain permission from the rights-holder(s) directly, unless additional rights are indicated by a Creative Commons license in the record and/ or on the work itself. This Dissertation has been accepted for inclusion in WVU Graduate Theses, Dissertations, and Problem Reports collection by an authorized administrator of The Research Repository @ WVU.

For more information, please contact researchrepository@mail.wvu.edu. 


\title{
EVALUATION OF WEANING REGIMEN AND SEMINAL PLASMA BIOLOGY ON REPRODUCTIVE MANAGEMENT IN CATTLE
}

\author{
By \\ John Fredrick Odhiambo, M.S. \\ DISSERTATION \\ Submitted to \\ The Davis College of Agriculture, Forestry and Consumer Sciences \\ at West Virginia University \\ In partial fulfillment of the requirements for the degree of \\ Doctor of Philosophy \\ In \\ Reproductive Physiology \\ Robert A. Dailey, Ph.D. Chair \\ E. Keith Inskeep, Ph.D. \\ Stanley M. Hileman, Ph.D. \\ Eugene E. Felton, Ph.D. \\ Phillip I. Osborne, Ph.D.
}

Division of Animal and Nutritional Sciences

Morgantown, WV

2008

Keywords:

Early weaning, Rump fat, Seminal plasma, TGF- $\beta 1$, Proteomics, Beef cows, Dairy cows. 


\section{ABSTRACT \\ Evaluation of weaning regimen and seminal plasma biology on reproductive management in cattle}

\section{John F. Odhiambo}

The goal of any reproductive management system in cattle is to ensure that cows breed at the earliest opportune time and maintain their pregnancy to term. However, delayed resumption of postpartum ovarian cyclic activity in primiparous beef cows and pregnancy losses in dairy cows continue to impede progress in obtaining sound reproductive efficiency in these species. Three studies were designed to test the following hypotheses: 1) Does removal of lactational stress in beef cows by early weaning of calves improve cow energy profile and postpartum reproductive performance? 2) Does artificial insemination (AI) with adjunctive seminal plasma (SP) or transforming growth factor beta-1 (TGF- $\beta 1$ ) improve conception rates in lactating dairy and beef cows? 3) Does seminal plasma of dairy bulls differ in expression of proteins that might be used as potential biomarkers of male fertility? In experiment 1, pregnant and lactating beef cows $(\mathrm{n}=408)$ were assigned randomly to wean calves either at $180 \mathrm{~d}$ of age (early weaning) or $45 \mathrm{~d}$ later (normal weaning). Body energy status was evaluated by periodic measurements of body weight (BW), body condition score (BCS), rib and rump fat. Reproductive performance was determined by calving intervals (CI), intervals from breeding to calving (BCI), retention in herd, and adjusted 205-d weaning weight of the subsequent calf. In experiment 2 , lactating beef $(n=1090)$ and dairy $(n=800)$ cows received $0.5 \mathrm{~mL} \mathrm{SP}, 40 \mathrm{ng}$ recombinant human TGF- $\beta 1$, or $0.5 \mathrm{~mL}$ bovine serum albumin (BSA) or were left untreated at insemination. Pregnancy was determined by transrectal ultrasonography 35 to $40 \mathrm{~d}$ post insemination or from records of calves born in the subsequent calving season. In experiment 3, seminal plasma from high $(\mathrm{n}=8)$ and low $(n=6)$ fertility bulls at Select Sires Inc. (Plains City, OH) were assayed for TGF- $\beta 1$ content, and subsequently analyzed by 2-D fluorescence difference gel electrophoresis (2-D DIGE) for presence of potential biomarkers of male fertility. Early weaning and cow age improved $(P<0.001)$ energy partitioning and production efficiency in beef cows. Rump fat measurements predicted body energy status better than BW or BCS $(P<$ $0.001)$. Inseminations with SP and/or TGF- $\beta 1$ numerically increased $(P=0.07)$ conception rates in beef and dairy cows. Concentrations of TGF- $\beta 1$ in seminal plasma were numerically greater $(P=0.25)$ in high fertility dairy bulls than those of low fertility. Expression of fertility associated proteins did not differ $(P>0.05)$ between high and low fertility bulls. However, their expression patterns were altered by semen processing. In conclusion, reproductive efficiency in primiparous beef cows can be improved by removal of lactational stress during mid to late pregnancy, while in dairy cows inseminations with adjunctive SP and/or incorporation of some seminal plasma proteins into semen during processing might improve conceptions rates after AI. 


\section{DEDICATION}

This dissertation is dedicated to my departed sister, Ms. Lillian Achieng whom l'll always miss dearly. 


\section{ACKNOWLEGMENTS}

With sincere and deep gratitude I would like to acknowledge Drs. R. A. Dailey, E. K. Inskeep, P. I. Osborne and E. E. Felton for their guidance throughout my graduate program and in the preparation of this dissertation. I would also like to appreciate the kindness of Dr. Stan Hileman for his willingness to fill in the void left in my committee by the sad departure of Dr. George Seidel.

I would like to thank the Division of Animal and Nutritional Sciences and Office of Minority Doctoral Programs, for the co-sponsorship of my program, and particularly Dr. Paul Lewis and Ms. Jennifer McIntosh for their wise counsel.

I extend my greatest appreciation to Mr. Dwayne O'Dell and Mark Pritt of the West Virginia Division of Agriculture for letting me use their herd and helping with the beef cow work. I gratefully acknowledge Mr. Ronnie Helmondollar and Jim Pritchard of West Virginia University Extension Service for helping me plan, coordinate, and carry out the beef cow work. I am grateful for the support of Mel DeJarnette and his staff at Select Sires Inc. with the dairy cow work and semen samples. I am grateful for the support of Dr. Lance Hughes for facilitating the work at Montana. I would also like to appreciate the guidance of Linda Corum and Steve Wolf at the Core Proteomics Laboratory during the time I worked at their lab.

Special thanks to my fellow graduate students, past and present: Dan Poole, Justin Rhinehart, Aimee Wurst, Raghuveer KR, Ida Holaskova, Gabrielle Rogers, Melanie Clemmer, Jill Koch, Katherine Jordan, Ezra Devonish, Brandon Lingenfelter, Caleb Lemley, Jason Gulas, Andrea Flanagan, Fernando Perea, Matt Dean, Julie Mankey, Tina Dow, Matt Packard, and Quinn Baptiste for their help and friendship. I acknowledge the inputs of former undergraduate students: Lindsay Shaffer, Justine Bolyard and Isaiah Smith for their contribution to the beef trials. I am indebted to the staff and inmates at the Huttonsville Correctional Institution Farm for their labor and dedication.

Last but not least, I acknowledge my family for their support and faith during the long academic journey. Specifically, my mum and dad (Rose and Joseph Agutu), my wife (Edwina Gogo), son (Jodi Omondi), and uncles (Victor and Dick Obungu) and their families. 


\section{Table of Contents}

ABSTRACT. ii

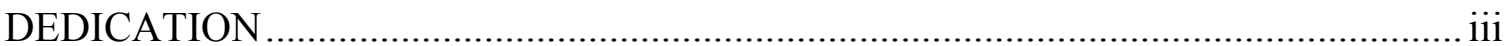

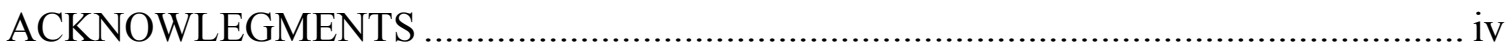

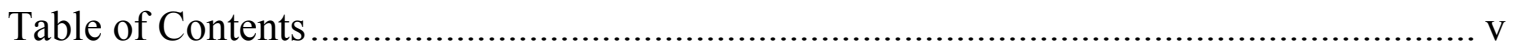

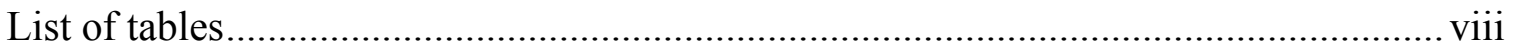

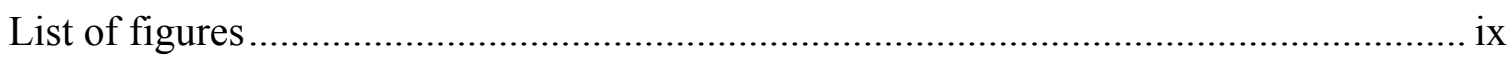

Evaluation of weaning regimen and seminal plasma biology on reproductive management

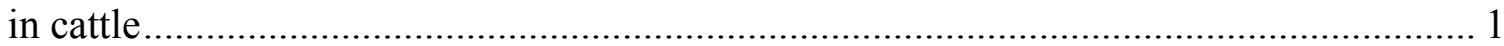

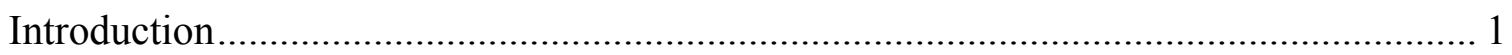

Current status of production practices in the dairy and beef industry in the United

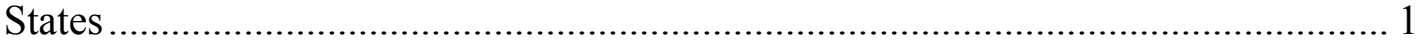

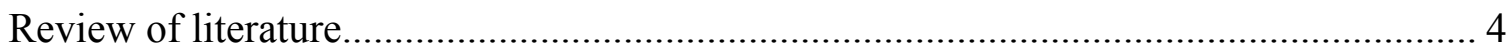

Reproductive physiology of the postpartum beef cow .............................................. 4

The three phases of the postpartum period ............................................................ 5

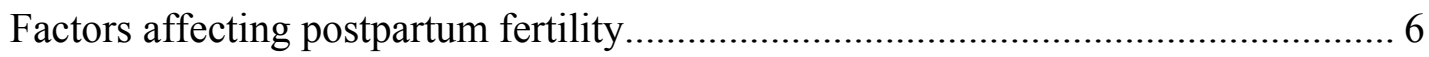

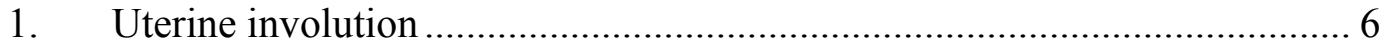

2. Short estrous cycles................................................................................ 7

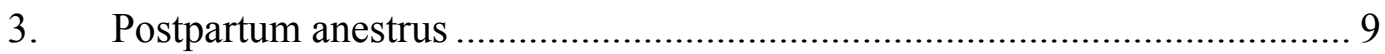

I. Establishment of the first ovulation postpartum ..................................... 10

II. Establishment of the first normal-length luteal phase .............................. 12

III. Risk factors for a prolonged postpartum interval.................................... 13

Factors affecting efficiency of the postpartum beef cow........................................ 14

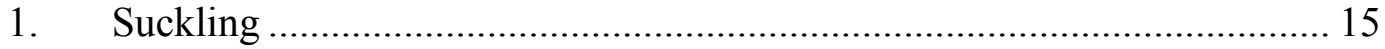

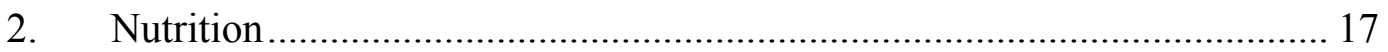

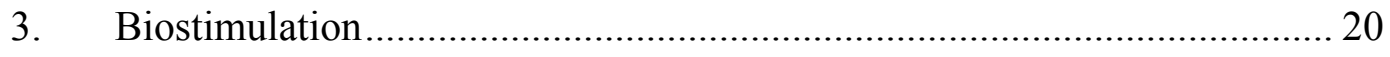

Manipulation of postpartum metabolic status....................................................... 21

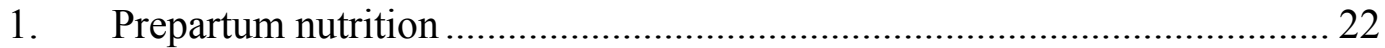

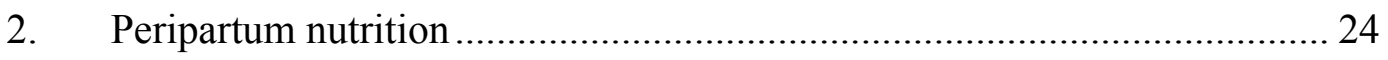

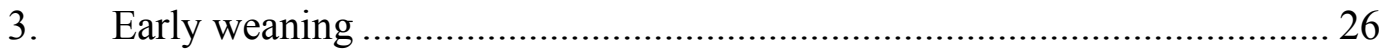

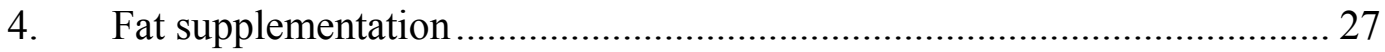


Measures of metabolic status of beef cows......................................................... 29

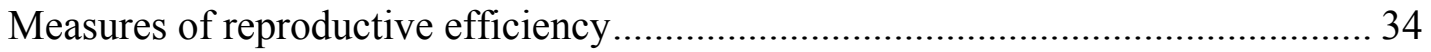

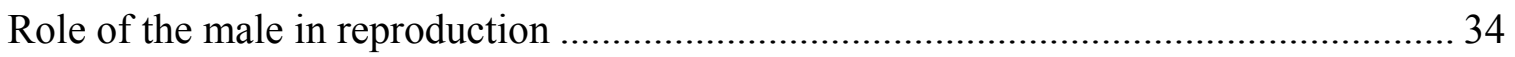

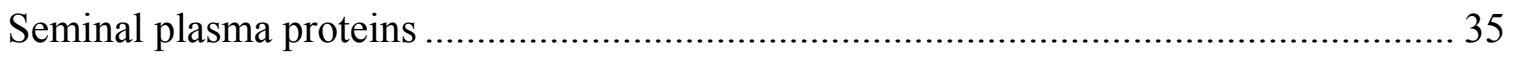

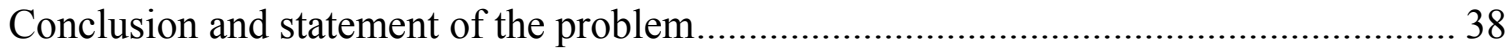

Experiment 1: Effect of weaning regimen on energy profiles and reproductive

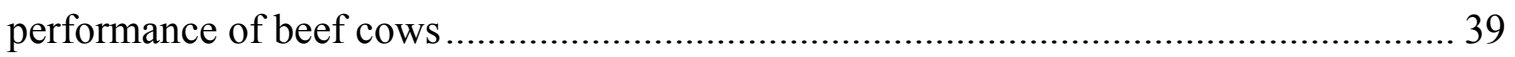

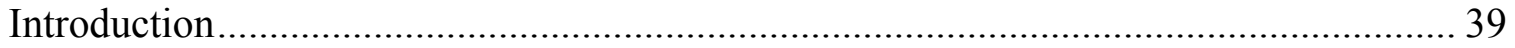

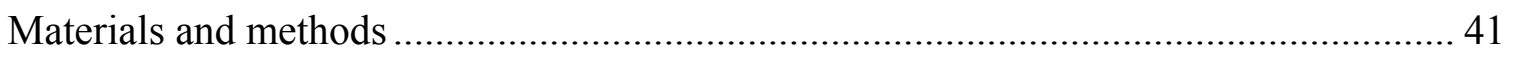

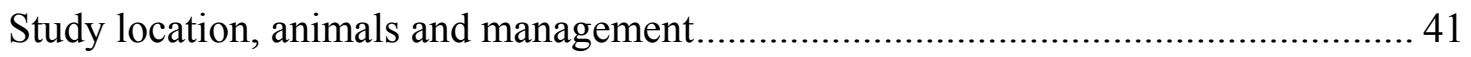

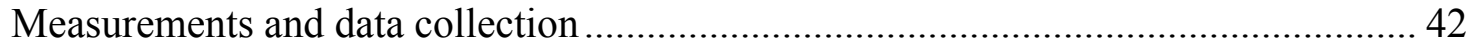

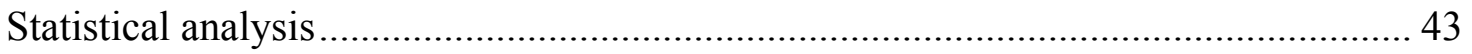

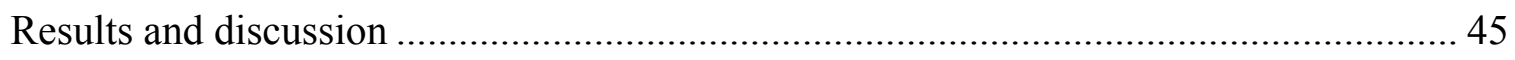

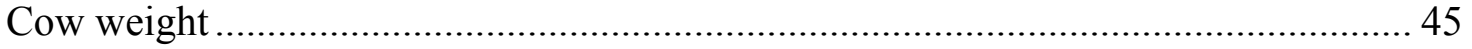

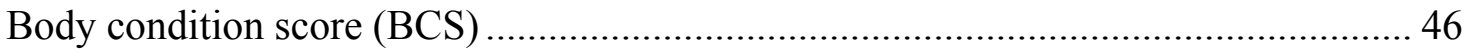

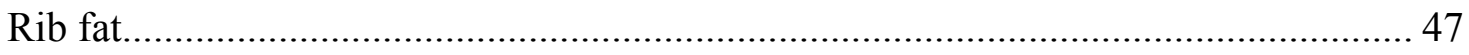

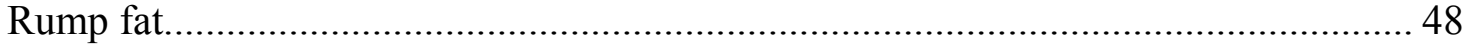

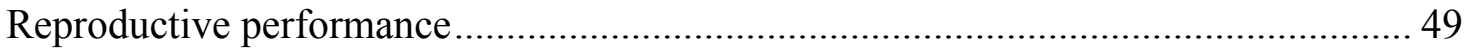

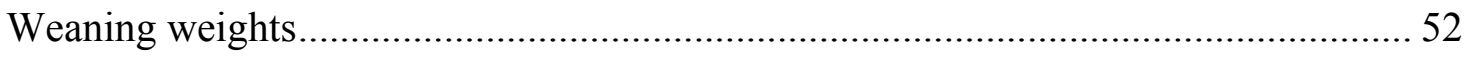

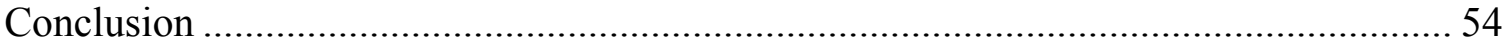

Experiment 2: Pregnancy outcome in dairy and beef cattle after artificial insemination with adjunctive seminal plasma or transforming growth factor beta-1 ......................... 64

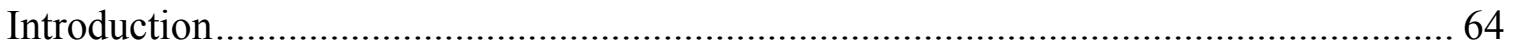

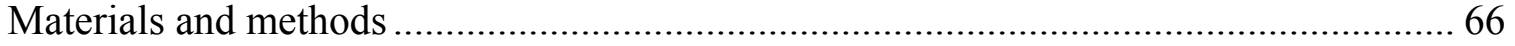

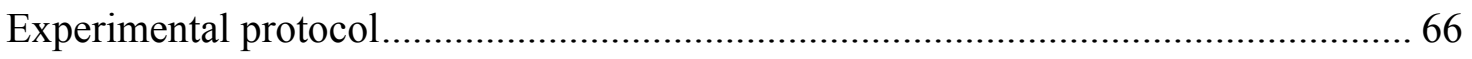

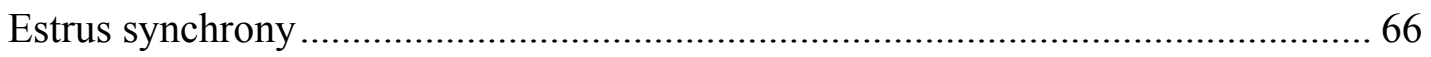

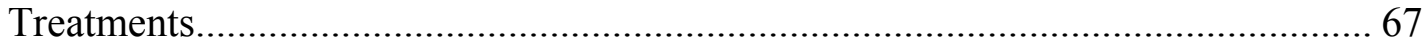

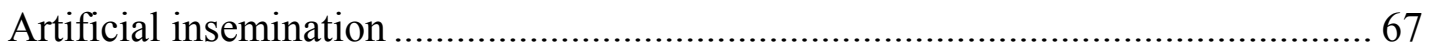

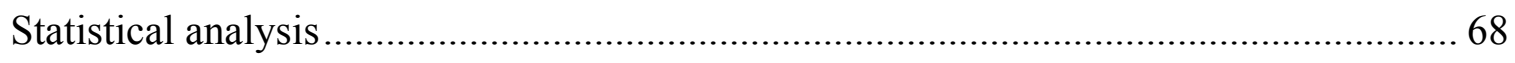

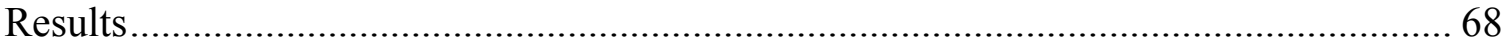

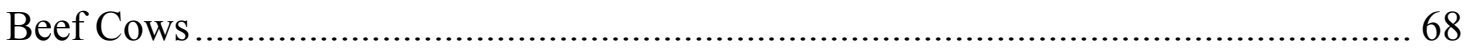




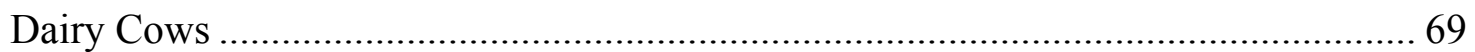

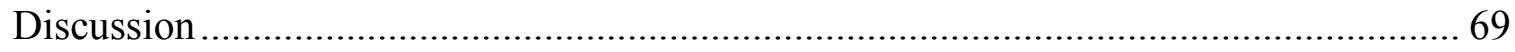

Experiment 3: Analysis of seminal plasma proteins in cryopreserved semen................ 76

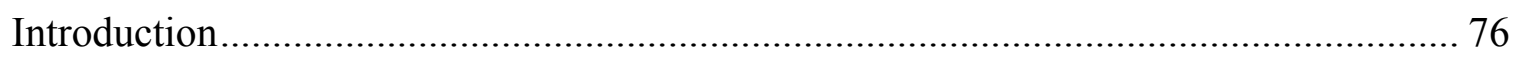

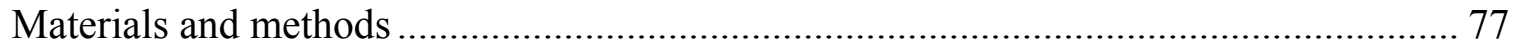

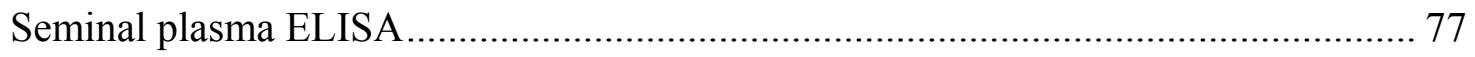

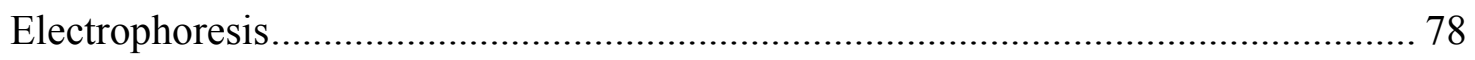

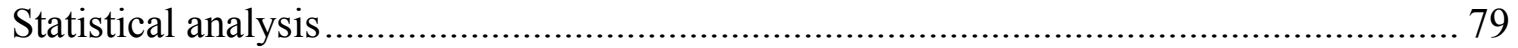

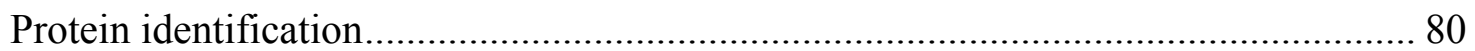

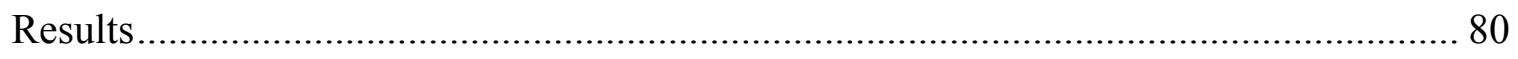

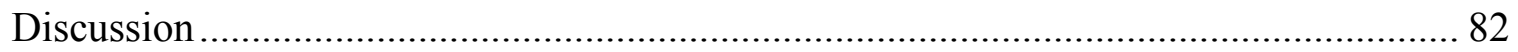

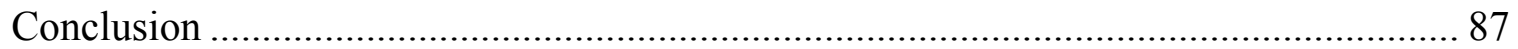

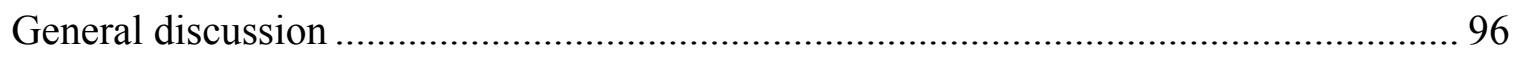

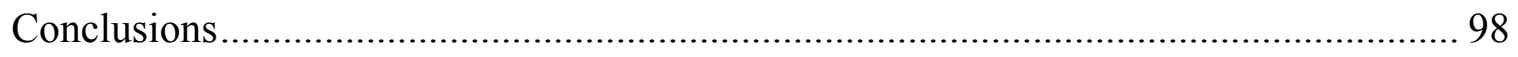

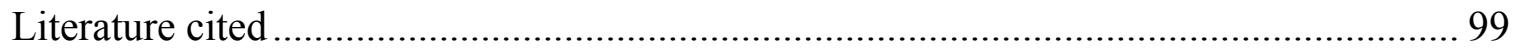




\section{List of tables}

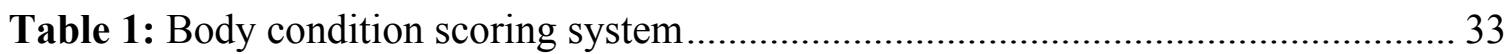

Table 2: Least squares means $\pm \mathrm{SE}$ of BW and BCS of cows 2 to $\geq 6$ years of age ....... 55

Table 3: Least squares means \pm SE for rib and rump fat of cows 2 to $\geq 6$ years of age.. 56

Table 4: Least squares means \pm SE rump fat $(\mathrm{mm})$ for age by treatment and by period. 57

Table 5: Least squares means \pm SE calving intervals (CI) and breeding to calving interval

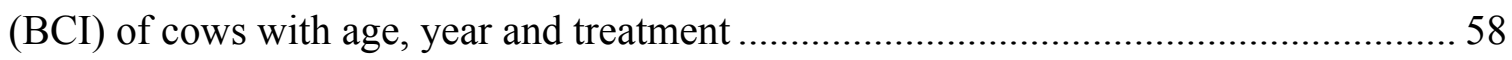

Table 6: Pairwise correlations of beef cow energy variables at selected....................... 59

Table 7: Comparison of retention pattern (\%) among cow age groups during the study 60

Table 8: Least squares \pm SE mean pregnancy rates for beef cattle inseminations

evaluating the effects of TGF- $\beta 1$, SP and BSA treatments on pregnancy outcome ${ }^{1} \ldots \ldots . . .74$

Table 9: Comparison of pregnancy rates (\%) among studies in beef and dairy cattle ..... 75

Table 10: Proteins identified from corresponding spots in figure 9 . ........................... 95 


\section{List of figures}

Figure 1: Least squares means $( \pm \mathrm{SE})$ for cow weight $(\mathrm{kg})$ adjusted to average body condition score $(\mathrm{BCS}=5.0)$ for every age category

Figure 2: Least squares means $( \pm \mathrm{SE})$ for cow rump $(\mathrm{mm})$ fat thickness adjusted to average body condition score $(\mathrm{BCS}=5.0)$ for every age category.

Figure 3: Least squares means \pm SE for calf adjusted 205-d weaning weights $(\mathrm{kg})$ by

cow age.

Figure 4: Concentrations of TGF- $\beta 1$ in seminal plasma of dairy bulls.

Figure 5: Concentrations of TGF- $\beta 1$ in seminal plasma of dairy bull of known fertility

phenotypes $(P=0.35)$.

Figure 6: Reference gel depicting distribution of protein spots in seminal plasma of dairy bulls

Figure 7: Analysis of distribution of protein spots by volume in seminal plasma of cryopreserved dairy bull semen. 91

Figure 8: Cluster analysis of protein expression in seminal plasma of dairy bulls.

Figure 9: Pick list for protein spots that differed between seminal plasma from processed and unprocessed dairy bull semen. Thirty spots from this list were picked and digested for protein identification by MALDI-TOF and LC-MS/MS mass spectrometry.

Figure 10: Mass ion spectrum of a positively identified protein by MALDI-TOF mass spectrometer. Colored bars indicate complemetary peptide matches with the protein sequence in database. Grey bars indicate no matching with data base sequences. 


\section{Evaluation of weaning regimen and seminal plasma biology on reproductive management in cattle}

\section{Introduction}

\section{Current status of production practices in the dairy and beef industry in the}

\section{United States}

The major goal of beef production is to enhance the efficiency of feed/forage utilization to produce abundant beef for increasingly health-conscious consumers and to improve the quality of human life. Beef herds in the United States and worldwide are managed under diverse conditions from confinement cow-calf production units to the more common open grazing systems in which quality of forages and roughages is often poor, particularly in dry and winter seasons (Wu et al., 2006). In recent years, the U.S. beef industry has lost a significant portion of its historically dominant market share due to changes in consumer preferences and to an increase in the price of beef relative to pork and poultry (Wachenheim and Singley, 1999). Changes in the beef industry to improve its competitive position have been slow and relatively unsuccessful for two reasons: First, biological realities dictate a much longer industry response time to changes in consumer demand, e.g., birth of the calf until it reaches market weight can take 1 to 1.5 years. Second, the nature of the beef production process, which includes cow ownership and up to 9 to 12 months on pasture, requires enormous capital and land investment, resulting in a very large pool of independent producers. These biological and economic differences make it unlikely that the beef industry could successfully adopt the integrated marketing channel structure of the poultry industry (Wachenheim and Singley, 1999). 
Nutrient requirements of the beef cow and nutrient availability in the forage-based production system fluctuate throughout the year. Maintenance represents 75 to $85 \%$ of the total requirement in pregnant dams because of substantial increases in maternal body tissue weight as well as metabolic rate. Nutrient requirements of the cow increase substantially after calving and continue to increase through peak lactation, which is generally attained by 45 to 46 days post calving. At the same time reproductive function must be supported in order to remain on an annual calving schedule. Management strategy would involve fluctuating body weight through nutritional manipulations to adequately suit the times that nutrients are available to cows. Alternatively, shifting calving seasons may influence the most appropriate time of weaning for optimal production. Several options from partial and temporary weaning to complete weaning are available for cattle producers to use time of weaning as a management tool to manipulate cow body condition (Whittier et al., 1995). Perhaps the most favorable months to change body condition in spring calving cows are September, October and November. Prior to these months, the demand for milk production is high and makes it difficult to increase cow condition. After these months, the impact of colder temperatures also makes it difficult to add condition because expensive and, often times, lower quality processed feeds are being fed.

The dairy industry in the United States has experienced significant progress in genetics and management resulting in a smaller number of dairy cows producing the bulk of the milk consumed. As a consequence, dairy farms are larger and fewer with nearly $30 \%$ of dairy cows on farms with 500 or more cows (Lucy, 2001). Selection for higher milk yield has negatively impacted fertility due in part to negative energy balance in the 
immediate post partum period (Butler, 2000) and/or increased plasma concentrations of somatotropin and prolactin, which are stimulators of lactation, and decreased insulin (Nebel and McGilliard, 1993). Insulin is antagonistic to lactation, but may be important for normal follicular development. Lower concentrations of blood progesterone and insulin-like growth factor-1 and greater embryonic losses also have been attributed to genetic selection for milk production (Lucy et al, 1998, Lucy, 2001). Although the relative contribution of individual factors leading to infertility can be debated, the cumulative effect erodes the efficiency and profitability of the dairy industry (Lucy, 2001).

The current study was designed to answer the following questions:

1. Can weaning in the first half of mid-gestation (August-September vs. October-November) alter metabolic status of the cow (from early-weaning) and translate into improved cow efficiency in reproduction and production? Specifically, are the subsequent postpartum intervals, pregnancy rates, weaning rates, and calf growth rates improved by early weaning?

2. Can suppression of inflammatory response to seminal antigens by treatment of cows with TGF- $\beta 1$ or seminal plasma at AI improve conception rates in lactating dairy and beef cows?

3. Can differences in fertility of dairy bulls be predicted by profiles of their seminal plasma proteins?

4. Does semen processing affect seminal plasma protein profile after cryopreservation? 


\section{Review of literature}

\section{Reproductive physiology of the postpartum beef cow}

Resumption of estrous cycles within a relatively short time-frame following parturition has long been recognized as a major milestone that must be reached for a cow to achieve optimal reproduction (Hess et al., 2005). Mechanisms associated with the acquisition and subsequent maintenance of reproductive competence in the postpartum beef cow result from functional integration of the hypothlamo-hypophyseal-ovarian axis.

The brain centers of the reproductive axis are structured such that neurosecretory neurons from the preoptic area and the medial basal hypothalamus $(\mathrm{MBH})$ terminate in the stalk median eminence where they deliver gonadotropin releasing hormone $(\mathrm{GnRH})$ to the hypophyseal portal blood system. The GnRH is then transported to the anterior pituitary and stimulates secretion of gonadotropins (FSH and LH). Tonic secretion of GnRH from the neurosecretory cells of the MBH stimulates the secretion of hypophyseal LH with surges occurring every 1 to 2 hours. Early follicular growth and development is initiated by $\mathrm{FSH}$, while $\mathrm{LH}$ aids in the final maturation of the dominant preovulatory follicle. Production of estradiol by ovarian follicles eventually reaches a threshold level causing neurosecretory neurons in the preoptic area to release a surge of GnRH, which in turn causes a high-amplitude surge release of LH leading to ovulation. Subsequently, the follicular cells are reorganized into a corpus luteum (CL) that secretes progesterone, which in turn suppresses GnRH release from the hypothalamus. Luteal regression and the accompanying decrease in serum concentrations of progesterone allow the process to be repeated. Maintenance of the CL caused by maternal recognition of pregnancy results in continued negative feedback effects of progesterone and anestrus throughout pregnancy. 
The anestrus continues into the postpartum period, even though the CL of pregnancy has reorganized into a syncytial structure and no longer secretes progesterone.

\section{The three phases of the postpartum period}

The three phases of the postpartum period have been reviewed extensively by Inskeep (1995), Jolly et al. (1995) and Macmillan et al. (1996). Gestational steroids, mainly progesterone and estrogens, have a suppressive effect on secretion of hormones from the hypothalamus and pituitary gland just as they do in cyclic animals (Lucy, 2003). Thus, the first phase involves recovery of the hypothalamus and pituitary gland from the effects of the previous pregnancy and resumption of FSH secretion and pulsatile LH release. The LH surge mechanism must also be re-established. This phase is relatively short, and cows normally have pulsatile secretion of LH within 1-2 weeks after parturition and recover the LH surge mechanism shortly thereafter. The second phase involves the process of uterine involution, a rapid process usually completed within 3040 days post partum. The timing of uterine involution coincides with recovery of fertility. Thus, most investigators consider uterine involution as the initial block to the reestablishment of normal fertility (Casida et al., 1968). The third phase is ovarian recovery, the most intensely studied area of reproduction in the postpartum cow. Follicular growth continues during pregnancy, but the diameter of the dominant follicles decreases perhaps due to a decrease in LH pulsatility during late gestation. Therefore, the first dominant follicle post partum will undergo one of three fates: 1) ovulation, 2) atresia, which is followed by a new wave of follicular emergence (turnover) or 3) cyst formation followed by atresia (Beam and Butler, 1999). The mechanisms that dictate these events are of keen interest to reproductive biologists. 


\section{Factors affecting postpartum fertility}

After parturition, cows are infertile for a variable period of time. Several factors contribute to that infertility. These include: 1) uterine involution, 2) short estrous cycles, and 3) postpartum anestrus.

\section{Uterine involution}

Casida et al. (1968) defined uterine involution as complete when the uterus returned to its normal nonpregnant position and when the two horns were similar in diameter and showed normal consistency and tone. The process of uterine involution was later described by Kiracofe (1980) to involve the reduction in size of the uterine horns, sloughing of tissue, and regeneration of the uterine epithelium. The entire process appears to be complete between 30 and 40 days post partum and 10 to 15 days earlier in the previously nongravid uterine horn (Wagner and Hansel, 1969).

An involuting uterus is a temporary barrier to fertility. Parturition is followed by a period when conception is not possible: one week in sows and about 3 weeks in cows and ewes. Estrus and ovulation seldom occur together during this period and, if fertilization occurred and the embryo reached the uterus, placentation would be virtually impossible (Kiracofe, 1980). Uterine involution is influenced by many factors: uterine infections, retained fetal membranes, and other parturient diseases delay the normal process (Morrow et al., 1966; Kiracofe, 1980). Suckling has been found to promote uterine involution (Casida et al., 1968; Riesen et al., 1968), delay uterine involution (Wiltbank and Cook, 1958) or have little effect on the rate of uterine involution (Wagner and Hansel, 1969; Oxenreider and Wagner, 1971). Age or parity influences uterine involution variably: involution might take a few days longer in pluriparous cows than in primiparous 
cows (Morrow et al., 1966; Gier and Marion, 1968; Arije et al., 1974) or not be affected by age or parity at all (Tennant et al., 1967). Season of the year has been reported to affect rate of uterine involution, with a slower rate occurring in fall than in spring (Kiracofe et al., 1969). Energy and protein levels of the diet only slightly affected the rate of uterine involution but drastically affected the interval from parturition to resumption of estrous cycles (Wiltbank et al., 1962; Dunn et al., 1969; Clemente et al., 1978). Uteri of cows fed high-energy diets after calving involuted three days sooner than uteri of cows fed moderate energy diets. However, protein levels in the diets affected the rate of uterine involution (Kiracofe et al., 1969).

Studies on ovulation and conception rates indicated that at the first estrus, the degree of uterine involution (as expressed by uterine horn diameter) is more of a fertility factor if ovulation occurs on the gravid horn than on the nongravid side (Casida et al., 1968; Foote and Peterson, 1968). In contrast Bridges et al. (2000) found greater success in the previously gravid horn. Short et al. (1974) found similar fertilization rates in cows bred before and after 20 days postpartum by surgical deposition of semen at the tip of the uterine horn and concluded that infertility during the first 20 days after calving is caused by a physical barrier to sperm transport and not by any inherent defect in the ova or other physiological mechanisms.

\section{Short estrous cycles}

Short estrous cycles contribute to postpartum infertility during the first 30 to 40 days after calving. Most estrous cycles after 40 days have normal length, although evidence exists that short estrous cycles will occur later (Lishman et al., 1979). The short estrous cycle phenomenon was one of the first abnormalities observed in the postpartum 
cow (Foote and Hunter, 1964; Casida, 1971; Short et al., 1972; Smith et al., 1987; Inskeep, 1995). The short-estrous-cycle syndrome is a practical beef cattle problem, because some cows exhibit estrus and are bred during the period that these estrous cycles occur, especially in more intensive operations, in which postpartum intervals are short and estrous synchronization is used (Short et al., 1990).

Ovulations following estrus destined to start a short cycle are normal with ova released that can be fertilized. However, no pregnancies were detected, apparently because the corpus luteum $(\mathrm{CL})$ regressed before the ovary received a signal from the uterus that pregnancy existed (Graves et al., 1968; Short et al., 1972, 74; Odde et al., 1980; Ramirez-Godinez et al., 1982b). The first ovulation after calving generally occurs without estrus (Lamming et al., 1981; Alberio et al., 1987; Murphy et al., 1990; MukasaMugerwa et al., 1991) and is followed by a short cycle ( 8 to 12 days) in the majority of cows (King et al., 1976; Williams and Williams, 1989; Murphy et al., 1990; Perry et al., 1991; Day et al., 1993).

Short cycles are common after ovulation induced by weaning (Odde et al., 1980; Ramirez-Godinez et al., 1982a; Copelin et al., 1987; Zollers et al., 1993; Breuel et al., 1993a), weaning plus GnRH (Williams, 1989), a single injection of GnRH (Foster et al., 1980; Copelin et al., 1988; Jagger et al., 1987), intermittent injections of GnRH (Wildeus et al., 1987; Jagger et al., 1987), continuous infusion of GnRH (Lofstedt et al., 1981), a single injection of hCG (Garcia-Winder et al., 1986; Johnson et al., 1992), and after first ovulation at puberty (Donaldson et al., 1970; Berardinelli et al., 1979). The short cycle is accompanied by a single follicular wave, a CL that is of smaller diameter than that during a normal cycle and subluteal concentrations of circulating progesterone (Yavas and 
Walton, 2000). Conception rate from artificial insemination at the first estrus postpartum was higher (76 vs. $41 \%$ ) if estrus was preceded by a short cycle (Werth et al., 1996).

Prostaglandin $\mathrm{F}_{2 \alpha}\left(\mathrm{PGF}_{2 \alpha}\right)$ appears to be the normal physiological signal whereby the uterus secretes $\mathrm{PGF}_{2 \alpha}$, which causes regression of the $\mathrm{CL}$ at the end of the estrous cycle. During the early postpartum period, high concentrations of $\mathrm{PGF}_{2 \alpha}$ probably prolong the interval to normal function of CL, because hysterectomy reduced systemic $\mathrm{PGF}_{2 \alpha}$ concentrations and restored normal function of CL (Lindell et al., 1982; Madej et al., 1984; Copelin et al., 1987). The early postpartum uterus produces and metabolizes large amounts of $\mathrm{PGF}_{2 \alpha}$, and suppression or infusion of $\mathrm{PGF}_{2 \alpha}$, which prolonged or shortened the lifespan of the CL, further implicates its role in the control of CL function in the postpartum cow (Guilbault et al., 1984). Therefore, the functional capabilities of the early-postpartum CL might be normal, but the CL is caused to regress prematurely by abnormally high $\mathrm{PGF}_{2 \alpha}$ concentrations from the uterus (Short et al., 1990). Normal CL function during an early postpartum estrous cycle can be obtained by pretreatment with a progestin (Ramirez-Godinez et al., 1982b; Breuel et al., 1993b). The mechanism associated with the progestin effect involves a reduction in $\mathrm{PGF}_{2 \alpha}$ with the effect mediated via the ovary rather than the pituitary (Short et al., 1990). Further clarification of this mechanism was provided by Kieborz-Loos et al. (2003), who showed that progestin priming permits estradiol $17 \beta$ and progesterone to induce adequate endometrial progesterone receptors so that secretion of $\mathrm{PGF}_{2 \alpha}$ is programmed to occur later in the luteal phase.

\section{Postpartum anestrus}


Postpartum anestrus is commonly measured or quantified as the interval from parturition to first estrus (PPI). In cattle, the average PPI in different studies ranged from 30 to 104 days (Short et al., 1990). This interval was prolonged by calf suckling with a more pronounced effect in beef cattle than in milked dairy cattle. It was longest following calvings in the winter, shortest in the summer, and intermediate in spring and autumn (Hammond, 1927). Ovulations without estrus occurred before the first expressed estrus in approximately $60 \%$ of the cows; suckling increased the number these events per cow in beef cows- probably more than in dairy cows (Casida, 1971).

In sows, postpartum estrus occurs in approximately $50 \%$ of sows within 4 days after parturition. This estrus is usually anovular with very little follicular development. Removal of pigs early postpartum is followed by ovulatory estrus near 12 days postpartum in approximately three-fourths of the sows, and ova are fertilizable at this time (Casida, 1971). In sheep, PPI is longest for ewes lambing from March to June, shortest for those lambing in September to December, and intermediate for January to February and July to August. Suckling of lambs prolonged the interval beginning any time in the year (Casida, 1971).

\section{Establishment of the first ovulation postpartum}

A period of anovulatory anestrus of varying duration is observed in milked and suckled cows following parturition. In milked dairy cattle the interval from parturition to first ovulation is typically between 19 and 22 days (Fonseca et al., 1983; Stevenson et al., 1983; Darwash et al., 1997). Under pasture-based management systems the mean interval is 43 days (McDougall et al., 1995) and in suckled cows it can vary between 20 to 86 days (Lamming et al., 1981; Murphy et al., 1990). 
Concentrations of gonadotropins are very low in late pregnancy due to strong negative feedback from progesterone and estrogens. After calving, concentrations of FSH increase within 5 to 10 days in both milked and suckled cows, whereas circulating LH concentrations generally start to increase between 10 to 20 days postpartum (Rhodes et al., 2003). Pulsatile episodes of LH release are first detected around this time in milked dairy cows, but are delayed in suckled beef and dairy cows, with frequency of pulses of LH release being correlated with the interval to first ovulation (Lamming et al., 1981; Beam and Butler, 1997; Crowe et al., 1998).

Growth and development of ovarian follicles, which can be detected by ultrasonography, commences within 1 or 2 days of the first significant rise in plasma FSH concentrations after calving (Beam and Butler, 1997; Crowe et al., 1998). A single large or dominant ovarian follicle commences growth around 10 to 14 days postpartum in both milked and suckled cows (Murphy et al., 1990; Savio et al., 1990; McDougall et al., 1995). This follicle may fully mature and ovulate, or become atretic and be replaced by one or more subsequent dominant follicles, or may continue growth and become cystic. Ovulation of the dominant follicle occurs when production of estradiol by the follicle is sufficient to stimulate a preovulatory surge of LH and FSH. Estradiol production is in turn dependent on sufficient gonadotropic support in terms of LH pulse frequency, and elevated plasma concentrations of insulin growth factor (IGF) -1 (Lamming et al., 1981; Stagg et al., 1998; Beam and Butler, 1999). Both IGF-1 and insulin, which are in greater concentration in plasma of cows receiving proper nutrition than in those not, are potent stimulators of steroidogenesis and proliferation of bovine granulosal and thecal cells in vitro, acting synergistically with FSH or LH (Rhodes et al., 2003). 


\section{Establishment of the first normal-length luteal phase}

The first postpartum ovulation is associated not only with absence of estrous behavior but also is often followed by a short luteal phase (Webb et al., 1980; Murphy et al., 1990; McDougall et al., 1995). Premature release of $\mathrm{PGF}_{2 \alpha}$ by the uterus, rather than inadequate luteal development is the main cause of the shortened life span of the first corpus luteum (Copelin et al., 1987; Zollers et al., 1989; Webb et al., 1980; Kieborz-Loos et al., 2003). Low or negligible concentrations of progesterone preceding the first postpartum ovulation result in lower numbers of progesterone receptors and greater numbers of oxytocin receptors in endometrial cells, allowing early development of the positive feedback loop between oxytocin and $\mathrm{PGF}_{2 \alpha}$ (Zollers et al., 1993). Low preovulatory concentrations of estradiol probably are involved in increasing the numbers of endometrial oxytocin receptors, thus allowing binding of oxytocin and premature release of luteolytic $\mathrm{PGF}_{2 \alpha}$ (Mann and Lamming, 2000). Oxytocin induced secretion of $\mathrm{PGF}_{2 \alpha}$ metabolite (PGFM) in cattle on day 5 of a short estrous cycle, and total PGF in invitro cultured day 5 endometrium from cows expected to have short luteal phases (Zollers et al., 1989; 1991).

A short period of elevated concentrations of progesterone during the postpartum period, from either endogenous or exogenous sources, is important for the expression of estrus as well as a subsequent normal luteal function (Henricks et al., 1972; RamirezGodinez et al., 1982; McDougall et al., 1995). Treatment of anestrous cows with progesterone is followed after withdrawal by greater concentrations of estradiol in follicular fluid and plasma, increased pulsatile release of $\mathrm{LH}$, and increased numbers of receptors for LH in granulosal and thecal cells in preovulatory follicles (Garcia-Winder et 
al., 1986; Inskeep et al., 1988; Rhodes et al., 2003). Estradiol and progesterone secreted by the preovulatory follicle may induce adequate production of uterine progesterone receptors that inhibit premature secretion of $\mathrm{PGF}_{2 \alpha}$; hence a normal length luteal phase is established (Kieborz-Loos et al., 2003).

\section{Risk factors for a prolonged postpartum interval}

Three categories of anovulation have been defined by using ultrasonography to observe ovarian follicular growth patterns: 1) Anovulation with follicular growth not progressing beyond the emergence stage of development may be observed in animals subject to severe nutritional restrictions, especially in Bos indicus breeds of cattle. This condition includes absence of any ovarian follicles $>8 \mathrm{~mm}$ in diameter, associated with inadequate or infrequent pulsatile release of LH (Jolly et al., 1995; Rhodes et al., 1995). 2) Anovulation with follicular growth to less than ovulatory follicular size has been observed in most cows that display a prolonged PPI and is the usual condition exhibited by postpartum suckled beef cows and dairy cows managed in pasture-based systems (Murphy et al., 1990; McDougall et al., 1995). This type of anovulation is associated with a relatively low frequency of pulsatile LH release and increased sensitivity to the negative feedback effects of estradiol on gonadotropin release. 3) Anovulation with follicular growth to larger than ovulatory follicle size (follicular cysts) may be observed in lactating dairy cows, but is uncommon in beef cows (Wiltbank et al., 2002). This category of anovulation covers a variety of physiological conditions and can be associated with an absence or excess of sexual behavior. It is thought to be related to increased release of LH with an insensitivity to estradiol positive feedback. The 
following portion of the review will mainly discuss factors related to the second category of anovulation.

\section{Factors affecting efficiency of the postpartum beef cow}

Evolution has produced a multitude of adaptations to ensure reproductive success in mammalian species. These adaptations include strategies for responding to a variety of external cues including photoperiod, food availability, ambient temperature, behavioral interaction, and tactile stimulation (Williams, 1990). In beef cattle production, reproductive performance is five times (Harpster et al., 1998) as important as growth of animals in the economics of the cow-calf enterprise. Unlike growth, there is little or no economy of scale with reproduction (Harpster et al., 1998), and, therefore, management should have a goal of maximizing reproduction. Reproductive success is linked to the three phases of animal production, which under usual management occur in an annual fashion: 1) calving and lactation, 2) breeding, and 3) gestation. Under the assumption that a cow produces a calf every 12 months and normal gestation is 9 months, it follows that the breeding season cannot exceed 3 months in length. This constraint of 90 days between calving and rebreeding limits reproductive efficiency and is influenced highly by nutrition of the cow over a longer period of time, particularly precalving (Wiltbank et al., 1962; Bellows and Short, 1978; Richards et al., 1986), as well as by suckling (Casida, 1971; Short, 1976; Edgerton, 1980), season (Hansen and Hauser, 1984; Hauser, 1984; Tortonese and Inskeep, 1992), and age/parity (Short et al., 1990). Although the limitation induced by each factor has independent influence, the factors co-exist and can therefore exacerbate the effects of one another. However, postpartum cows are anestrus because of 
two primary reasons: 1) lactational anestrus caused by suckling stimulus or 2) nutritional anestrus caused by inadequate energy stores (Short et al., 1990).

\section{Suckling}

Suckling is one exteroceptive stimulus that plays a major role in governing reproductive cycles in female mammals (Edgerton, 1980; Williams, 1990). Suckling has a limited but intensive effect on cow reproductive performance. Its chronic presence during lactation has important biological and economic implications in a variety of species including swine, cattle, certain breeds of sheep, the laboratory rat, and the human being (Williams, 1990). Biological effects in farm species range from near total blockage of ovulation in the domestic sow to little or no impact in the seasonally breeding ewe, in which external cues for reproduction are derived from changes in photoperiod (Hammond, 1944; Kenneway et al., 1987; Goodman, 1988). Although the beef cow holds an intermediate position within this ranking, because of its economic importance, it has commanded extraordinary attention for studying postpartum anestrus in general and suckling-induced anestrus in particular (Edgerton, 1980; Wettemann, 1980, Williams, 1990).

Suppression of cyclic ovarian activity during the early postpartum period is characteristic of the suckled beef cow (Stagg et al., 1998). Both dietary energy restriction (Dunn and Kaltenbach, 1980; Browning et al., 1994) and poor body condition (Rutter and Randel, 1984) exacerbate this effect. Mean intervals from parturition to first ovulation in suckled cows range from 50 to 100 days (Casida, 1971; Oxenreider and Wagner, 1971; Wettemann et al., 1986; Williams 1990). Intervals to first estrus averaged 65 to 104 days (Graves et al., 1968; Wiltbank, 1970; Casida, 1971), and factors that contributed to this 
variability included breed, environment, disease, and nutritional status. The cow-calf interaction is critical in prolonging postpartum anestrus in beef cows (Lamb et al., 1997; Stagg et al., 1998). A cow must bond to her naturally-born calf or establish a new bond with an unrelated calf before the associated suckling will maintain anestrus. When cows nursed unrelated calves continuously (established a new cow-calf bond) or nursed an unrelated calf continuously in the presence of their own non-suckling calves (still bonded to own calf), their intervals to first ovulation were similar to those of cows nursing their own calves, and each (interval to first ovulation) was greater than that of cows from which calves had been weaned (Lamb et al., 1997). In addition, masectomized cows maintained with their non-suckling calves from parturition to weaning had longer intervals to first ovulation than masectomized cows whose calves were weaned within 24 h after birth (Viker et al., 1993; Stevenson et al., 1994). Neither muzzling (Macmillan, 1983) nor nose-plating (Mukasa-Mugerwa et al., 1991) calves shortened anestrus in their non-suckled dams. Therefore, a cow's perception of a calf suckling the inguinal region with or without an intact mammary gland is enough stimulus to prolong anestrus.

Nursing frequency, intensity and duration have been considered to be the primary determinants of the length of postpartum anestrus. Clearly, exaggerated suckling stimuli lengthen the postpartum interval in most mammals (Wettemann et al., 1978). However, in two other studies, variation in suckling frequency by single calves was unrelated to rebreeding activity in their dams (Williams et al., 1984b; Day et al., 1987). Frequent milking of beef cows ( 5 times/d) in the presence of their calves failed to simulate the mechanisms associated with suckling-induced anovulation (Lamb et al., 1999). In dairy cows, frequent milk removal by milking 3 times, 6 times or 3 times milking plus 3 times 
suckling prolonged the interval to first ovulation, with suckling plus milking having the greatest effect (Stevenson et al., 1997). However, delaying suckling for up to $8 \mathrm{~h}$ after milking increased the proportion of cows ovulating within $100 \mathrm{~d}$ of calving and shortened the calving to first ovulation interval in dual purpose cows (Perez-Hernandez et al., 2002).

The most overriding cause of anestrus in suckled beef cows is chronic suppression of LH release, which prolongs the suppressed pattern found immediately after calving due to the effects of gestational steroids (Moss et al., 1981; Stagg et al., 1998). Indeed, even after these steroids have been cleared from the circulation, the presence of ovarian factors (primarily estradiol) play a major role in the ability of suckling to limit release of gonadotropins (Acosta et al., 1983; Garcia-Winder et al., 1984; Chang and Reeves, 1987). This may occur as a result of increased sensitivity to negative feedback effects of estradiol, as well as to a relative inability to respond to positive estradiol feedback within the first three weeks postpartum (Short et al., 1979).

Management approaches to diminish the suppressive effects of suckling on ovarian activity have been proposed. These include temporary calf removal (Smith et al., 1979), once daily suckling (Bell et al., 1998) and early weaning (Arthington and Kalmbacher, 2003). Temporary calf removal requires that cows calve in a body condition score (BCS) $\geq 5$ to be effective (Smith et al., 1979). However, the beneficial effects of once daily suckling and early weaning likely could be negated by extra costs in providing alternative feed to the calves and by calf welfare issues involved.

\section{Nutrition}


Nutrition is a major factor affecting cow reproductive efficiency. Animals become anestrus when they lose on average 22 to $24 \%$ of their initial body weight (Diskin et al., 2003). The effects of nutrition have been measured most commonly using energy as a variable. Other nutrients may affect reproduction, but their effects are not as well documented. The postpartum return to estrus is a complex combination of endocrine and environmental events that is mediated largely by the nutritional status of the cow (Harpster et al., 1998). Nutrients are partitioned for various body functions in an approximate order of priority. Basal metabolism, activity, growth, and basic energy reserves have priority over reproductive processes, such as onset of cyclicity, and establishment and maintenance of pregnancy (Short et al., 1990; Yavas and Walton, 2000). The relative priority of these functions can change depending on production status of the animal. During periods of reduced nutrient demand, e.g. late lactation and dry period in dairy cows and post-weaning period and mid-gestation in beef cows, excess nutrients are stored in the body in the form of fat. The amount of fat deposits in animals can be quantitatively or visually expressed as BCS ranging from 1 (thin) to 9 (obese) as described by Wagner et al. (1988) and is likely a good indicator of metabolic status of the animal. The stored nutrients can be retrieved later to maintain production during periods of negative energy balance (Grimard et al., 1995), such as the postpartum period, when nutrient demand exceeds voluntary feed intake, or periods of limited nutrient availability, e.g. during drought, mid-late summer, or winter.

The effect of energy on reproductive performance was studied in a classical work by Wiltbank and colleagues (1962) in mature Hereford cows fed two levels of energy: 9 lbs of total digestible nutrients (TDN) per head per day (High) and $4.5 \mathrm{lbs}$ of TDN per 
head per day (Low) prior to calving. After calving, one-half of the cows on the high ration and one-half of the cows on the low ration received $16.0 \mathrm{lbs}$ of TDN per head daily (high-high and low-high). The remaining cows received $8.0 \mathrm{lbs}$ of TDN per head daily (high-low and low-low). Cows maintained on low energy diets (low: low) showed longer intervals to estrus and lower pregnancy rates $(52 \mathrm{~d}, 20 \%)$ than cows switched from high to low energy diets at calving (43d, 77\%). They concluded that the level of dietary energy provided to cows in the prepartum period was relatively more important than that provided after calving.

Conception rates of $32 \%$ in cows receiving low protein intake compared to $74 \%$ in cows with higher protein intake receiving isocaloric diets in both pre-and postpartum periods were reported by Sasser et al. (1988). In the same study, first service conception rates were suppressed ( 25 vs. $71 \%$ ) in beef cows receiving inadequate protein diets compared to adequately fed herd mates. Kaim et al. (1983) reported that fertility was impaired more by feeding excess protein to dairy cows in their fourth or later lactation than for younger cows. However, protein supplements with high potential for rumen escape, undegradable intake protein (UIP), and positive profile of essential amino acids have been shown to improve reproduction when fed in excess of NRC recommendations (Triplet et al., 1995). In that study, when postpartum first-calf heifers and mature cows were fed $56 \%$ of their supplemental protein as UIP, first-service conception rates increased by $28 \%$ over herd mates fed $38 \%$ UIP. The percentage of first-calf heifers showing normal first postpartum estrus (with CL formation) and milk production also was increased. The increased milk production increased average daily gain (ADG) of calves, resulting in heavier weaning weights (Triplet et al., 1995). 


\section{Biostimulation}

The role played by males in reproductive function in addition to mating is well documented. In many species, association with males triggers neuroendocrine reflexes that alter reproduction (negatively or positively) in females. The Bruce effect, in which pregnant mice abort if exposed to a male mouse of a different strain or even if placed in a cage that was recently vacated by such a male, provides an example of a negative effect of males on reproduction. A positive example is induced ovulation in the domestic cat or rabbit, where copulation is requisite for ovulation (Clemens and Christensen, 1975).

Biostimulation is a term that describes the stimulatory effect of a male on estrus and ovulation through genital stimulation or possibly through pheromones. Factors that affect the response of postpartum anestrous cows to the biostimulatory effect of the bull are not well understood. However, exposing postpartum, anestrous, primiparous suckled beef cows to close physical contact with bulls (Berardinelli and Tauck, 2007) or androgenized cows (Burns and Spitzer, 1992) accelerated the resumption of ovarian activity. In one study, in which multiparous cows were exposed to bulls within 3 days of parturition, onset of estrus was advanced by about 20 days compared to cows isolated from bulls until 53 days postpartum (Zalesky et al., 1984). In prepubertal heifers, biostimulation has yielded inconsistent results. Exposure of prepubertal heifers to vasectomized bulls for 18 to 30 days (Berardinelli et al., 1978) or from 9.5 to 15 mo of age (152 d) (Roberson et al., 1987) failed to elicit any effects on advancement of puberty. However, the majority of heifers exposed to bulls from 11.5 to 14 mo (76 d) had initiated ovarian activity by the time of breeding at 14 mo of age (Roberson et al., 1991). 
Olfactory and auditory signals have been implicated as possible cues for biostimulation, as have been direct genital contact and allelomimetic behavior. Nuzzling, nudging or licking of the perineal region of a female by a bull might initiate estrous behavior (Spitzer, 1998). Pheromonal stimuli excreted in urine or feces are involved in the mechanism of the biostimulatory effect of the bull (Berardinelli and Joshi, 2005). Subsequent findings that close physical contact between cows and bulls enhanced the biostimulatory effects added another factor to this mechanism, thus, the intensity of the stimuli (i.e. frequency, duration of exposure, and quantity of the stimuli) provided by the bull is integral (Berardinelli and Tauck, 2007). Hence, failure of biostimulatory response in studies that utilized intermittent contact (Fernandez et al., 1996) and fence line contact across a 6-8 m alleyway (Shipka and Ellis, 1998, 1999) could have been caused by less intensity of signal from the bulls.

\section{Manipulation of postpartum metabolic status}

Reproduction is a major component of production efficiency for the cow-calf system. When nutrient intake is inadequate and energy reserves are depleted, interval from calving to first estrus is extended (Wiltbank et al., 1962, 64; Morrison et al., 1999). In dairy cows, a closer relationship was found between BCS and days open at first artificial insemination (AI) than at parturition, because at first AI, most cows are recovering from postpartum metabolic stress (Lopez-Gatius et al., 2003). Postpartum metabolic stress can be minimized when cows are allowed to calve in moderate BCS, because mobilization of body fat stores might be limited in thin cows and considerable in fat cows (Lopez-Gatius et al., 2003; Jorritsma et al., 2003; 2005). 
Energy intake and body energy stores influence concentrations of energy substrates and hormones in the blood of cattle; chronic and acute alterations in substrates (mainly glucose and nonesterified fatty acids) and metabolic hormones (insulin, IGF-1 and leptin) might signal the hypothalamic-pituitary-ovarian (HPO) axis about metabolic status of the animal (Wettemann et al. 2003). Macronutrients or their metabolites regulate gene expression and influence growth and body functions in addition to their roles as sources of energy. While circulatory concentrations of these macronutrients in the postpartum cow are related to BCS at calving, reduced nutrient intake and suckling exacerbate their negative effects on the HPO axis (Wettemann et al., 2003). Several studies have used varying nutritional treatments (pre- and peri-partum) and other management practices (early weaning) to effect change in postpartum metabolic status of cows (Wiltbank et al., 1962; Houghton et al., 1990; Osoro and Wright, 1992; Morrison et al., 1999).

\section{Prepartum nutrition}

The study by Wiltbank et al. (1962) on effects of varying nutritional regimens on postpartum reproduction contributed notably to the present understanding that postpartum metabolic status is conditioned by pre-partum nutritional status of gestating cattle. Morrison et al. (1999) examined the influence of prepartum BCS on postpartum reproductive performance of multiparous cows. Six months before the beginning of calving season, cows were blocked by body weight and BCS and randomly assigned to two equal groups: a) Gain group, weaned and stocked on high-quality pasture plus supplemental feed to gain 1 to 2 units of BCS; b) Restricted group, grazed low-quality pastures at increased stocking rates or fed restricted amounts of hay and continued to 
suckle their calves past the usual weaning date to lose 1 or 2 units of BCS. Approximately $90 \mathrm{~d}$ before calving, cows were regrouped by $\mathrm{BCS}$ (BCS $\leq 4$, group 1; $\mathrm{BCS}=5$ to 6 , group $2 ; \mathrm{BCS} \geq 7$, group 3 ) and managed so that each cow would calve at a BCS of 5 to 6 . Cows in group 1 were fed good quality hay or corn silage plus supplemental protein ad libitum, while group 3 cows' nutrient intake was restricted by limiting hay intake or grazing fescue pastures at high stocking rate to limit forage availability. After parturition, all cows were managed together as one group.

Body weight and condition scores of gain- and restricted-groups were different at 90 d prepartum, but not at parturition. Prepartum BCS change did not affect pregnancy rates at 20,40, or $60 \mathrm{~d}$ of the breeding season. Mean interval from calving to conception was $87 \mathrm{~d}$ and was not affected by prepartum BCS changes. Birth weights of calves were not affected by prepartum changes in body weight of the cow. Pregnant cows tended to buffer the adverse effects of undernutrition on their developing fetuses by utilizing body energy reserves, thus losing weight and body condition. These findings further substantiate the concept of a target BCS at calving and indicate that a minimum BCS of 5 in multiparous beef cows will ensure that body energy reserves are adequate for acceptable postpartum reproductive performance.

In contrast, primiparous cows required greater $\mathrm{BCS}(\geq 6)$ at calving than mature cows to optimize subsequent reproductive performance (DeRouen et al., 1994; Spitzer et al., 1995). This is necessitated by higher demands placed on the body stores of nutrients for young cows (DeRouen et al., 1994). In the latter study, primiparous cows calving at BCS $\geq 6$ had shorter intervals from calving to pregnancy (74 vs. 82 d) and higher 
pregnancy rates ( 87 vs. $71 \%$ ) than their contemporaries calving at BCS of 5 . Thus, at BCS of 5, energy reserves in young cows were not adequate for optimum rebreeding.

\section{Peripartum nutrition}

The initial portion of this section presented a discussion of metabolic adaptations that occur in the dairy cow around the time of parturition. The same mechanisms may be observed in the beef cow at lesser magnitudes due to genetic differences in lactational performance.

Dairy cows experience an enormous metabolic challenge during the peripartum period due to increased preparturient energy and nitrogen demand by the conceptus and lactogenesis (Bell, 1995). Fetal energy requirements on Day 250 of pregnancy have been calculated to be $2.3 \mathrm{Mcal} / \mathrm{d}$ for Holstein cows (Ingvasrtsen and Andersen, 2000). These energy and accompanying nitrogen requirements of the ruminant conceptus are met almost exclusively by placental uptake of glucose and amino acids from the maternal circulation (Bell, 1995; Ingvasrtsen and Andersen, 2000). Therefore, maternal adaptation to the increased nutrient demand by the conceptus involves an increase in hepatic gluconeogenesis or decreased glucose utilization by peripheral tissues and an increase in reliance of maternal tissues on non-esterified fatty acids (NEFA) and ketones for oxidative metabolism (Bell, 1995; Ingvastsen and Andersen, 2000). The onset of lactation imposes dramatic increases in requirements for glucose, amino acids, and fatty acids that cannot be met by dietary intake. These shortfalls are met by major metabolic adaptations that include total suppression of lipogenesis and enhancement of lipolytic responses in adipose tissue and enhanced hepatic gluconeogenesis (Bell, 1995; Ingvasrtsen and Andersen, 2000; Jorritsma et al., 2003). These metabolic changes evoked 
by the difference in energy uptake and energy requirements, frequently referred to as negative energy balance (NEB), often have repercussions on subsequent fertility (Jorritsma et al., 2003; 2005). Therefore, nutritional goals at this time should be to maintain intake, or in the event of depressed intake, energy intake must be maximized (Grummer et al., 2004). These adjustments may be more beneficial if initiated in the prepartum period rather than in the immediate peripartum period.

Nutritional stresses associated with late gestation and early lactation are expressed by elevated concentrations of growth hormone and NEFA and decreased concentrations of insulin in plasma and can be alleviated by protein supplementation in the prepartum period. Sletmoen-Olson et al. (2000) showed that cows fed low-quality prairie grass hay for the last three months of gestation and first three months of lactation or supplemented with low undegraded intake protein (UIP) mobilized their adipose tissue to meet nutrient requirements more than their contemporaries supplemented with moderate or high UIP. Dry matter intake (DMI) and energy balance of postpartum cows can be improved by increasing energy density of prepartum diets (Doepel et al., 2002). In that study, cows fed high energy (HE) diets $(1.65 \mathrm{Mcal} / \mathrm{kg} \mathrm{NE}$ ) for the last 21 days of gestation had greater postpartum DMI and more positive energy balance than cows fed low energy (LE) diets (1.30 Mcal $/ \mathrm{kg} \mathrm{NE}$ ). Consistent with the improved energy balance of the HE cows, concentrations of NEFA in plasma and hepatic triglyceride content were higher relative to LE cows. However, increased protein content of the prepartum diets had no beneficial effects in the postpartum metabolic variables other than reducing muscle protein degradation, as evidenced by a shift in peak plasma 3-methylhistidine concentration from calving to one week postpartum in cows on low protein diets than in cows on high protein 
diets. In a previous related study, Marston et al. (1995) reported that cows fed energy-rich diets in the prepartum period gained more bodyweight and lost less BCS before calving than cows fed protein-rich diets. The advantage in BCS was continued through the breeding season and was measurable at weaning time. This observation led them to conclude that high energy feeding prepartum may have permitted cows to mobilize greater amounts of fat after calving or rather to have larger amounts of glycogen reserves available for early lactation.

Roche et al. (2005) allocated 52 prepartum dairy cows to treatments of 5.4, 8.2, 10.0 , or $11.0 \mathrm{~kg} / \mathrm{d}$ of pasture dry matter per cow per day for 27 days before calving. Precalving concentrations of glucose, IGF-1 and leptin in plasma increased quadratically with increasing pasture intake. They observed an associated linear decline in precalving plasma concentrations of growth hormone, and quadratic declines in concentrations of NEFA and $\beta$-hydroxybutyrate (BHBA) with increasing DMI. After calving, concentrations of these metabolites in plasma showed no lasting effect of precalving feeding. They concluded that cows that consumed less DM precalving had higher postpartum DMI and experienced less negative energy balance in early lactation.

\section{Early weaning}

Shifting weaning dates can improve cow-calf performance (Houghton et al., 1990; Grimes and Turner, 1991; Story et al., 2000; Arthington and Kalmbacher, 2003). Most reports indicate that improvements in steer weaning weights can be achieved with early weaning (Houghton et al., 1990; Grimes and Turner, 1991; Myers et al., 1999a,b) and that subsequent improvement in cow weight gain and BCS result from removal of lactation requirements for the early-weaned cows (Story et al., 2000; Arthington and 
Kalmbacher, 2003). Removing calves from cows at 30 to 45 days postpartum (Houghton et al., 1990) or 80 to 150 days postpartum (Grimes and Turner, 1991; Story et al., 2000; Arthington and Kalmbacher, 2003) might be considered in some production systems to improve overall efficiencies when forage quality and (or) quantity are inadequate to support lactation and optimal calf performance. In these instances, it may be more efficient and economical to feed early-weaned calves directly rather than to provide expensive supplemental feed to support lactation in cows (Houghton et al., 1990). Myers et al. (1999b) reported increasing cow weights and BCS as weaning age decreased from $215 \mathrm{~d}$ to $90 \mathrm{~d}$ and concluded that lactating cows responded to increased lactational demands by mobilizing their body energy reserves. An earlier study by Whitman (1975) indicated possible interactions among nutritional status, body condition of the cow and suckling. He reported that when energy intake is marginal, suckling and subsequent nutritional stress of lactation might reduce the energy available for reproduction. This was confirmed later in the study by Houghton et al. (1990a), in which early weaning of calves at 30 days postpartum increased estrous activity of cows within 60 days postpartum compared with normal-weaned cows. An additional advantage was expressed in cows that received adequate postpartum energy.

\section{Fat supplementation}

The use of fat supplementation in manipulating postpartum metabolic status and ovarian cyclic activity in dairy and beef cows has yielded inconclusive results. Whether these inconsistencies are caused mainly by animal stress levels or by type of fatty acids included in diets have necessitated current studies and may influence future studies too. Pre- or postpartum supplementation of beef cows with whole corn germ meal for $45 \mathrm{~d}$ did 
not have any effect on BCS or bodyweight change during late gestation, early lactation or in the subsequent grazing season (Martin et al., 2005). Postpartum supplementation did not affect ovarian activity before onset of breeding season, pregnancy rate nor subsequent calving interval in that study. Neither did supplementation with rice bran or lasalocid affect postpartum body weight or BCS in multiparous Brahman cows (Webb et al., 2001). However, in first-calf beef heifers supplemented with 4.7, 3.8 and 5.1\% fat in diet for the 65 days of gestation, pregnancy rates were 94,90 and $91 \%$ compared to $79 \%$ in control heifers receiving isocaloric diets with $2.4 \%$ added fat (Bellows et at., 2001, reviewed by Funston, 2004). Supplementation with $5.5 \%$ fat in diet from whole cottonseed 30 days before the breeding season increased the number of cows with BCS 4 cycling at the start of breeding season by $18 \%$ compared to control diet without added fat (Wehrman et al., 1991).

Elucidating how supplemental fat can influence reproductive function has been difficult. Currently, research is inconclusive on exactly how supplemental fat improves reproductive performance beyond the energy contribution (Funston, 2004). Supplemental fat stimulated programmed growth of a preovulatory follicle, increased total number of follicles, and increased the size of the preovulatory follicle (Mattos et al., 2000). Increased size of the preovulatory follicles may be due in part to increased concentrations of plasma LH, which stimulate the latter stage of follicular growth. Thus, ovulation of larger follicles may result in formation of larger corpora lutea with increased steroidogenic capacity resulting in greater progesterone production. Increased progesterone concentrations may improve pregnancy rates in animals fed supplemental dietary fat. 
Increased pregnancy rates observed with fat supplementation may be mediated by reduced $\mathrm{PGF}_{2 \alpha}$ secretion from the uterus and decreased sensitivity of the corpus luteum to $\mathrm{PGF}_{2 \alpha}$ (Mattos et al., 2000). Suppression of $\mathrm{PGF}_{2 \alpha}$ action and maintenance of the corpus luteum are obligatory steps for establishment of pregnancy in cows, and failures in this process can cause the loss of up to $40 \%$ of pregnancies (Thatcher et al., 1994). Dietary polyunsaturated fatty acids can decrease $\mathrm{PGF}_{2 \alpha}$ synthesis by decreasing the availability of precursor arachidonic acid, increasing the concentration of fatty acids that compete with arachidonic acid for processing by prostaglandin $\mathrm{H}$ synthase (PGHS), and inhibiting PGHS (Mattos et al., 2000).

\section{Measures of metabolic status of beef cows}

Metabolic status of cattle can be assessed by measurement of concentrations of metabolites in plasma (Wettemann et al., 2003; Ciccioli et al., 2003; Lents et al., 2005). Alternatively, noninvasive techniques such as BCS, body weight, and ultrasonic scanning of fat thickness (Rastani et al., 2001) provide relevant information about the metabolic status of cattle. In this portion of the review, the relevance of BCS in predicting metabolic status of beef cows is discussed.

For many years, progressive cow-calf producers have recognized an important relationship between physical appearance of their cow-herd and reproductive performance. Body condition scoring merely formalizes this time-practiced procedure by placing a quantitative score on the relative degree of fatness or energy reserves that can be observed or palpated. The nutritional status or balance of an animal, evaluated through BCS, reflects the body reserves available for basal metabolism, growth, lactation and activity, and body fat indicates stored energy (Montiel and Ahuja, 2005). 
Body condition score is a subjective method based on visual and tactile appraisal of metabolic energy stored as subcutaneous fat and muscle in the back and pelvic regions of an animal and is usually scored on a scale of 1 to 5 in dairy cows (Pryce et al., 2001, Montiel and Ahuja, 2005) and 1 to 9 in beef cows (Wagner et al., 1988; Table 1). Cattle generally deposit subcutaneous fat in the body in the following order: back or loin, ribs, tailhead, brisket, flank, vulva and/or rectum, udder or mammary gland. When requirements exceed nutrient intake and subcutaneous fat is broken down, it is utilized in the reverse order (Encinias and Lardy, 2000). Body condition score changes throughout lactation in the dairy cow, responding to changes in energy balance (Coffey et al., 2003). As milk yield peaks and demand for energy exceeds intake, the cow mobilizes her lipid reserves and gets thinner, thereby compromising her condition (Banos et al., 2004).

Research has shown a strong correlation between the current scoring system and actual fat deposition in the animal. The present scoring system takes into account 80 to 90 percent of the total variation in fat of a beef cow (Wagner et al., 1988; Hardin, 1990). Lents et al. (2005) found positive correlations between BCS and plasma concentrations of IGF-1, insulin and leptin at day-109 postpartum in gestating beef cows. Previously, Ciccioli et al. (2003) had demonstrated that inadequate nutrition uncoupled the GH-IGF-1 axis, leading to a decline in BCS and when nutritional status was reversed, BCS increased concurrent with plasma concentrations of IGF-1 and insulin. Interestingly, several studies reviewed by Wettemann et al. (2000) indicated that relationships between these metabolites (IGF-1, insulin and leptin) and BCS varied with nutrient intake. When cows were in a fed state, a stronger relationship between BCS and the metabolites existed, whereas, when cows were fasted, the relationship was not evident. Therefore, it would be 
rational to conclude that plasma concentrations of IGF-1, insulin and leptin may signify transient metabolic status whereas, BCS may provide a more stable estimate of cow metabolic status.

For consistent herd evaluations, a single individual should score cattle over successive years, because the subjectivity of the scoring system usually results in variation among individuals assigning scores. According to Encinias and Lardy (2000), important factors to consider when scoring cows include age, breed, and frame size. Older cows tend to carry less condition over their top than younger cows. Fat deposition varies with breed or type of cattle; dairy- and Brahman-influenced cattle carry less subcutaneous fat and more internal fat than British or Continental type cattle. Small- to moderate-framed cattle (Angus and Hereford) are often scored higher than larger cattle. Evaluators are encouraged to use palpation in situations in which cows exhibit thick hair coats, are shrunk, or are in late stages of pregnancy. Shrink can alter the appearance and feel of cows by as much as one score, while late pregnancy will tend to make a cow look fuller and fatter (Blasi et al., ND).

However, the predictive nature of the BCS system and individual variability in assigning scores may make it less accurate in measuring metabolic status of cows. Therefore, a combination of BCS and body weight or backfat depth could be used to correct for discrepancies obtained by using BCS alone. Direct relationships between BCS and body weight have been demonstrated (Houghton et al., 1990b; Buskirk et al., 1992; Tenant et al., 2002). However, Rastani et al. (2001) reported breed differences among dairy cows in the relationship between BCS and fat thickness, and they suggested that a 
third variable (week of lactation or milk composition) be used in estimating metabolic status of dairy cows. 
Table 1: Body condition scoring system

Score

Description

1

Severely Emaciated. All ribs and bone structure easily visible and physically weak. Animal has difficulty standing or walking. No external fat present by sight or touch.

2

Emaciated. Similar to 1 but not weakened.

3

Very Thin. No palpable or visible fat on ribs or brisket. Individual muscles in the hind quarter are easily visible and spinus processes are very apparent.

4

Thin. Ribs and pin bones are easily visible and fat is not apparent by palpation on ribs and pin bones. Individual muscles in hind quarter are not apparent.

5

Moderate. Ribs are less apparent than 4 and have less than 0.2 inches of fat on them. Last two or three ribs can be felt easily. No fat in the brisket. At least 0.4 inches of fat can be palpated on the pin bones. Individual muscles in the hind quarter are not apparent.

6 Good. Smooth appearance throughout. Some fat deposition in the brisket. Individual ribs are not visible. About 0.4 inches of fat on the pin bones and on the last two to three ribs

$7 \quad$ Very Good. Brisket is full, tailhead and pin bones have protruding deposits of fat on them. Back appears square due to fat. Indentation over the spinal cord due to fat on each sides. Between 0.4 and 0.8 inches of fat on last two to three ribs.

8 Obese. Back is very square. Brisket is distended with fat. Large protruding deposits of fat on tailhead and pin bones. Neck is thick. Between 1.2 and 1.6 inches of fat on last two to three ribs. Large indentation over spinal cord.

Very Obese. Description of 8 taken to greater extremes.

Adapted from Wagner et al. 1988. 


\section{Measures of reproductive efficiency}

Reproduction is a major component of the productive efficiency for a cow-calf system (Wiltbank et al., 1961; Short et al., 1990; Montiel and Ahuja, 2005). The number of calves born per year per cow exposed to breeding was identified as one of the key components of reproductive efficiency in beef herds (Osoro and Wright, 1992). This factor is in turn influenced by calving interval, conception rate, and embryonic survival (Wiltbank et al., 1961) as well as prolonged postpartum anestrus (Short et al., 1990, Montiel and Ahuja, 2005). Duration of postpartum anestrus is affected mainly by nutritional status (Short et al., 1990; Randel, 1990; Harpster et al., 1998; Diskin et al., 2003) and suckling status (Edgerton, 1980; Wettemann, 1980, Williams, 1990). Other factors such as uterine involution and age interact with the above mentioned factors and further influence reproductive efficiency of cows (Casida et al., 1968; Kiracofe, 1980; Short et al., 1990).

From a meta-analysis of the effects of BCS and change in BCS on reproductive performance of lactating dairy cows, Lopez-Gatius et al. (2003) made the following observations: 1) pregnancy rate at first AI was reduced for cows calving in poor condition compared to those calving in intermediate condition, 2) cows with a low BCS at parturition remained open for approximately 6 days longer than cows in the intermediate category, 3) severe loss of BCS (a drop in score of over 1 unit) during early lactation led to a significant increase of 10.6 days open relative to animals undergoing a slight loss in body condition, and 4) cows in poor condition at first AI needed 12.2 more days to become pregnant compared to cows in the intermediate BCS category.

\section{Role of the male in reproduction}


The traditional role of the male in reproduction has undoubtedly remained unchallenged. Other than provision of germ cells required for fertilization, there is no other significant role attached to the male in the reproductive process in mammals. However, in some aquatic species, male pregnancy, extended male parental care, and monogamy exist (Jones et al., 2003).

As discussed in the previous section, biostimulatory effects of the male have been exploited to accelerate the onset of puberty in females, to stimulate resumption of cyclic activity in females undergoing seasonal or lactational anestrus, and also to alter times associated with estrus and ovulation (Clemens and Christensen, 1975; Chenoweth, 1983). Genital stimulation of the female by the male prepared the female genital tract for optimal gamete transport (VanDemark and Hays, 1952) and tactile stimulation improved conception rates to $\mathrm{AI}$ in cows but not in yearling heifers (Randel et al., 1975).

\section{Seminal plasma proteins}

Seminal plasma proteins have been classified into two main categories based on their binding properties: 1) Spermadhesins or heparin-binding proteins predominant in boar, stallion and ram, and 2) proteins that contain fibronectin type II (Fn-2) domains generally referred to as bovine seminal plasma (BSP-A1/A2 and BSP-A3) proteins (Maxwell et al., 2007).

The BSPs are closely related proteins which exhibit multiple binding and functional properties. Upon ejaculation, they bind to the choline phospholipids of the sperm and prevent premature capacitation. They also bind to sperm capacitation factors, namely heparin and high-density lipoproteins (HDL), as the spermatozoa reach the oviduct, thus mediating capacitation. Hence, Fn-2 domain proteins are thought to perform 
protective and restoring roles to ejaculated spermatozoa. Among the BSP proteins, BSP$30-\mathrm{kDa}$ is the best mediator of sperm capacitation induced by heparin or HDL on epididymal spermatozoa, and its presence on the sperm membranes corresponds to increased fertility of bulls (Bellin et al., 1998; Moura et al., 2006).

Spermadhesins are a group of 12 to $16 \mathrm{kDa}$ proteins with carbohydrate-binding activity that constitute the majority of secretions by the seminal vesicles in the pig and horse. Because of their known interactions with heparin and zona pellucida, they may be involved in capacitation and oocyte recognition (Einspanier et al., 1994; Jonakova et al., 1998; Reinert et al., 1996). Spermadhesin 1, commonly referred to as acidic seminal fluid protein (aSFP), found in seminal plasma from bulls, also stimulates cell division and secretion of progesterone from granulosal cells in vitro, which could ultimately influence ovulation (Einspanier et al., 1991). However, some spermadhesins might inhibit the normal signaling pathway associated with initiation of capacitation and/or mask zona pellucida ligands in the sperm surface. The porcine spermadhesin heterodimer, porcine seminal plasma protein-I/II (PSP-I/PSP-II) is able to preserve viability and acrosome integrity and block oocyte penetration by frozen-thawed but not fresh boar spermatozoa (Caballero et al., 2004). Low fertility of dairy bulls has been associated with higher expression of Spermadhesin Z13 isoforms in accessory gland fluid (Moura et al., 2006).

Phospholipase $\mathrm{A}_{2}\left(\mathrm{PLA}_{2}\right)$ comprises a family of ubiquitous calcium iondependent enzymes capable of hydrolyzing the $s n$-2-position of phospholipids, releasing free fatty acids and lysophospholipids. Most PLA 2 characterized to date belong to either one of the two main groups: high $(85-\mathrm{kDa})$ and low (14-20-kDa) molecular mass PLA $\mathrm{A}_{2}$ In the reproductive system, $\mathrm{PLA}_{2}$ has been localized on the surface of ejaculated sperm 
(Ronkko, 1992) and is widely accepted to play a major role in the late maturational events of spermatozoa, particularly in the acrosomal reaction. The sperm $\mathrm{PLA}_{2}$ is also implicated in sperm-egg fusion. A secreted form of $\mathrm{PLA}_{2}$ has been purified from seminal plasma of various mammalian species (Soubeyrand et al., 1997). The secreted PLA $_{2}$ is believed to stimulate cytokine release by immune cells and exert a potent antimicrobial action in the seminal plasma (Moura et al., 2006).

There have been attempts to correlate fertility potential of bulls with proteins present in seminal plasma. Four proteins were proposed by Killian et al. (1993). These proteins were later identified as Osteopontin (Cancel et al., 1997), Phospholipase A2 (Manjunath et al., 1994), Spermadhesin Z13 and BSP-30kDa (Moura et al., 2006). The usefulness of these correlations as a basis for assessment of individual males or of their ejaculates, and their application in semen processing and preservation, is yet to be determined. The possibility of fertility associated proteins on the sperm surface has also been considered (Sutovsky, 2003; Peddinti et al., 2008). An active molecular mechanism of sperm quality control has been linked to epididymal sperm ubiquitination (Baska et al., 2008). Therefore, defective spermatozoa would be targeted for proteolytic degradation making ubiquitin identification a potential biomarker of sperm quality.

Fahmi et al. (1995) reported that bovine seminal plasma is immunosuppressive and cytotoxic to bovine lymphocytes. Transforming growth factor (TGF)- $\beta 1$ was purified and reported to be the active immune modulatory factor in seminal plasma (Tremellen et al., 1998). Studies in infectious diseases have concluded that TGF- $\beta$ plays this essential role by down-regulating the production of potentially pathogenic proinflammatory cytokines such as interferon- $\gamma$, tumor necrosis factor- $\alpha$ or interleukin 12 (Omer et al., 
2003). Hostile immune responses to seminal antigens would be incompatible with the maintenance of fertility and would prevent the female tract from tolerating future exposure to semen (Robertson, 2005). There would also be consequences for pregnancy, because the conceptus shares paternal antigens with those in semen (Thaler 1989). However, the immune activation elicited by semen does not activate the rejection of male antigens, because of the presence, in seminal plasma, of several powerful immunoregulatory molecules, such as PGE and TGF $\beta$, which prevent the destructive Type-1 (cell-mediated) immune responses (Letterio and Roberts, 1998; Weiner, 2001). Thus, the female tract immune response to semen conversely appears to result in a state of functional immune tolerance to male antigens (Robertson, 2005).

\section{Conclusion and statement of the problem}

This review has demonstrated that: 1) the timely resumption of estrous cycles within a defined breeding season is a hallmark that initially dictates whether a beef cow will produce a calf on an annual basis. 2) Return to estrus is orchestrated via an integration of multiple signals within the hypothalamo-hypophyseal-ovarian axis. 3) Energy balance, which is perceived by the reproductive axis as a variety of nutritionally induced cues, has a profound effect on the duration of the postpartum anestrus. 4) Seminal plasma proteins might evoke their immune-modulatory or membrane stabilizing activity in the female tract in support for fertilization and pregnancy maintenance.

Over 40 years ago, failure to conceive or early embryonic death accounted for the largest loss in calf crop in beef production (Wiltbank et al., 1961). Three decades later, failure to conceive during the breeding season was reported to account for the greatest production loss in the cow-calf segment of the beef industry (Bellows and Short, 1994). 
Most recently (Geary, 2003), the most common reproductive problem facing beef producers is getting first calf heifers re-bred. In most operations, pregnancy rates of either 2- or 3-year-old cows are the lowest in the herd. Logically then, reducing the lactational stress in the pregnant younger cow, which is still growing, by early weaning might lead to increased body energy reserves at calving and minimize the effects of negative energy balance on her postpartum interval and breeding performance.

In the dairy industry, poor oocyte quality (Ahmad et al., 1995; Perry et al., 2007) and failure of attachment (Starbuck et al., 2004; Rhinehart et al., 2008) account for the largest pregnancy losses. In a recent review of embryonic death in cattle, Inskeep and Dailey (2005) reported that about $10 \%$ of pregnancy failures in cows occur due to factors associated with the male. However, little attention has been paid to contributions in pregnancy failures due to male factors. Whether proteins present in the seminal plasma of ruminants could be characterized and utilized as additives to improve fertility of females after AI should be considered in the context of new research.

\section{Experiment 1: Effect of weaning regimen on energy profiles and reproductive performance of beef cows}

\section{Introduction}

The role of prepartum nutrition in reproductive performance of beef cows was demonstrated by the pioneer work of Wiltbank et al. (1962). Subsequent researchers modified their designs to include changes in duration of feed restriction at different stages of gestation (Morrison et al., 1999) and cow ages (DeRouen et al., 1994; Spitzer et al., 1995), but the outcome has been very consistent. Thus, a minimum body condition score of 5 (multiparous beef cows) or 6 (primiparous beef cows) on a 9-point scale (Wagner et 
al., 1988) at calving is recommended for timely resumption of estrous cycles within a defined breeding season to produce annual calf crops. Return to estrus is orchestrated via integration of multiple signals within the hypothalamo-hypophyseal-ovarian axis; energy balance, which is perceived by the reproductive axis as a variety of nutritionally induced cues, has a profound effect on the duration of postpartum anestrus (Hess et al., 2005).

Nutrient requirements of beef cows increase during pregnancy, but in temperate environments nutrient availability may be inadequate during the latter portion of pregnancy, when requirements increase most rapidly. In that case, cows catabolize body tissue to support conceptus growth. With inadequate supplementation programs, such cows will calve at lower body condition and may experience an extended postpartum anestrus. Supplementing grazed forages with harvested feed during pregnancy should prevent the cow from losing body tissue. However, there are costs associated with supplemental feeding, including cow feed efficiency and specific feed cost. Freetly and Neinaber (1998) reported that time of the annual reproductive cycle when feed resources are offered can be altered with minimal effect, thus allowing for flexibility in managing feed resources. Geary (2003) reported that nutritionally, the most affected age groups are the primiparous cows, and in most beef herds, getting these first-calf heifers to re-breed has been problematic. Hence, pregnancy rates of 2- or 3-year-old cows are often the lowest in the herd, and the effect is carried over to the $2^{\text {nd }}$ calving (Ottobre and Lewis, 1983). Logically then, reducing the lactational stress by earlier weaning might lead to increased body energy reserves at calving and minimize the effects of negative energy balance on their postpartum intervals and breeding performance. This alternative management practice has the potential to decrease postpartum interval, increase 
pregnancy rates and longevity within a cow herd. Therefore, the objectives of this study were to evaluate the effect of shifting time of calf weaning on 1) cow body energy profiles throughout the production cycle, and 2) postpartum reproductive efficiency.

\section{Materials and methods}

\section{Study location, animals and management}

The study was conducted using a State-owned commercial beef herd in Huttonsville, WV. The farm is located in the Tygart Valley in Randolph County, West Virginia, adjacent to the Monongahela National Forest ( $\left.38^{\circ} 53^{\prime} \mathrm{N}, 79^{\circ} 51^{\prime} \mathrm{W}\right)$. The climate of the county is generally cooler than most parts of the eastern United States. The average mean annual temperature at the Elkins-Randolph County Airport is $9.5^{\circ} \mathrm{C}$. Three months have average mean temperatures below freezing with January's $-2.7^{\circ} \mathrm{C}$ being the coldest. Four months have average mean temperatures in the teens, while July's $20.4^{\circ} \mathrm{C}$ is the warmest. The elevation is about $625 \mathrm{~m}$ above sea level. The nearby Elkins airport receives on average, $1137 \mathrm{~mm}$ of precipitation annually, including $942 \mathrm{~mm}$ of rainfall and another $196 \mathrm{~mm}$ from melting of frozen precipitation.

The breed composition in the herd was predominantly Angus with about $1 / 3$ Hereford and Charolais crosses. Average cow age in the herd was 4 to $5 \mathrm{yr}$, but ranged from 2 to 12 years of age. Cows were managed on natural pastures all year round and supplemented with harvested forages during winter months. Forage species present in the pastures were primarily orchard grass (Dactylis glomerata L.), tall fescue (Lolium arundinaceum), white and red clover (Trifolium repens L. and T. pratense L.), and, in less proportion, Kentucky bluegrass (Poa pratensis) and timothy (Phleum pratense L.). Data were collected from 135 (year 1) and 150 (years 2 and 3) spring-calving cows 
whose calves averaged 6 mo of age in September. Peak calving season occurred in March but began in early February and lasted till early April. Breeding season lasted $60 \mathrm{~d}$ during the study period beginning mid-May till mid-July. Cows were maintained in separate breeding age groups (2-, 3-4-, $\geq 5$-yr old) during the breeding season. Bull to cow ratio was maintained at approximately 1:20.

Cows were stratified by age, and by sex and weight of their calves and assigned randomly into two treatment groups: early weaning at approximately $180 \mathrm{~d}$ of calf age (early weaning, $\mathrm{n}=90 \mathrm{yr} 1$, and $100 \mathrm{yr} 2$ and 3) and normal weaning $45 \mathrm{~d}$ later (control, $\mathrm{n}=45 \mathrm{yr} 1$, and $50 \mathrm{yr} 2$ and 3) with weaning groups stratified to cow ages. The study was conducted over a 12-month period beginning at first weaning in September (early weaning) and ending at weaning of the next calf in September of the subsequent year and replicated for 3 yr. Time points of interest were: 1) early weaning, 2) normal weaning, 3) pre-calving (average 3 weeks before start of calving season), 4) postpartum (average 60 days after start of calving season), 5) breeding (average 30 days after end of calving season), and 6) end of breeding ( $60 \mathrm{~d}$ after start of breeding season). Cows were managed as one herd and reassigned among treatment groups each subsequent year.

\section{Measurements and data collection}

All experimental procedures were approved by the West Virginia University Animal Care and Use Committee. Body weights were recorded and BCS were assigned to the cows by visual appraisal by a single evaluator at each weighing period based on a scale of one to nine $(1=$ thin and $9=$ obese, Wagner et al., 1988). Fat thickness was measured by a certified ultrasound technician over the rump and rib using an Aloka ${ }^{\circledR} 500$ ultrasound console and a $5.0 \mathrm{MHz}$ probe (Aloka America, Willingford, CT). The 
transducer was placed above the interface between the biceps femoris and the gluteus medius muscles for rump fat, and on the intercostal region between the $12^{\text {th }}$ and $13^{\text {th }}$ rib for rib fat. The ultrasound images were analyzed at the National Centralized Ultrasound Processing (CUP) Laboratories. Pregnancy diagnosis was performed at the end of each breeding period by transrectal ultrasonography using an Aloka ${ }^{\circledR} 900$ console with a 7.0 $\mathrm{MHz}$ probe (Aloka America, Wallingford, CT). Calving interval was calculated as the interval from one calving to the next. Days from breeding to calving (BCI) were calculated as the number of days from start of breeding season to actual calving date. Calving and weaning rates in subsequent years were used as indicators of production efficiency in the herd. Cow retention pattern in the herd was indicated by the frequency of calving and weaning within the 3-yr study period.

\section{Statistical analysis}

Data on cow weights, BCS, rib and rump fat, and composition scans were analyzed as repeated measures in a split plot design using the mixed procedures of SAS (SAS Inst. Inc., Cary, NC). The subject for repeated measures was cow within age and treatment. Main plot variables included cow age, treatment, and the interaction term. Subplot variables included period, and its 2- and 3-way interaction terms with cow age and treatment. Linear, quadratic, and cubic contrasts were tested for age and period effects. Effects of cow age on BW and rump fat were further evaluated using the GLM procedures of SAS in a second model that adjusted the variables to a constant BCS (5.0). The model statement included BW and rump fat as dependent variables, age as a class variable and BCS as a covariate. Differences among least squares means were determined by Tukey's multiple comparison tests. 
Reproductive performance was evaluated in terms of 1) retention in the herd, which was obtained from proportion of cows that weaned calves $(\times 100=\%$ retention $)$ of those present at previous breeding season, 2) number of days from start of breeding period until calf birth $(\mathrm{BCI}), 3)$ calving interval $(\mathrm{CI})$, and 4) performance of the subsequent calf. Cows that calved and subsequently weaned that calf were assigned a value of 1 , and those that had no calf were assigned a value of 0 . Calf performance was evaluated by adjusted 205-d weaning weight. Analyses for BCI, CI and calf performance were evaluated using PROC GLM in SAS according to the following model:

$$
\begin{aligned}
& Y_{i j k l}=\mu+T_{i}+C_{k}+T_{i k}+B_{j(i)}+e_{i j k l} \\
& \text { Where } \\
& Y_{i j k l}=\text { the } 1^{\text {th }} \text { cow of the } j^{\text {th }} \text { year in the } i^{\text {th }} \text { treatment in the } \mathrm{k}^{\text {th }} \text { age group; } \\
& \mu=\text { overall mean; } \\
& T_{i}=\text { effect of the } i^{\text {th }} \text { treatment; } \\
& C_{k}=\text { effect of the } \mathrm{k}^{\text {th }} \text { age group; } \\
& \mathrm{TC}_{\mathrm{ik}}=\text { interaction term for the } \mathrm{i}^{\text {th }} \text { treatment and } \mathrm{k}^{\text {th }} \text { age group; } \\
& \mathrm{B}_{\mathrm{j}(\mathrm{i})}=\text { effect of the } \mathrm{j}^{\text {th }} \text { year in the } \mathrm{i}^{\text {th }} \text { treatment; and } \\
& \mathrm{e}_{\mathrm{ijkl}}=\text { random error associated with } \mathrm{Y}_{\mathrm{ijkl}} \text {. }
\end{aligned}
$$

Least squares mean differences were determined by Tukey's LSD at $\alpha=0.05$. Retention pattern was analyzed by contingency tables using JMP (SAS Institute, Cary, $\mathrm{NC}$ ). Relationships between BCI, CI, cow age, BCS, rib and rump fat were determined by polynomial analysis using JMP. Pairwise correlations were performed among all energy variables with reproductive variables at selected periods using JMP. 


\section{Results and discussion}

Complete data sets were available for 408 cows for BW, BCS, rib and rump fat analysis, 314 cows for $\mathrm{CI}$ and BCI analysis, and 252 cows for evaluation of subsequent adjusted 205-day calf weaning weights.

\section{Cow weight}

Weaning treatment did not influence $(P=0.34)$ overall cow weight profile, however, an interaction of treatment with period $(P<0.001)$ affected weight at normal weaning time (data not shown). Hence, upon cessation of suckling, cows were able to compensate for reduced weight gain during the interval from early to normal weaning. A linear response $(P<0.001)$ for cow age by weight indicated increased weight gain from 2 to 4 years of age and marginal gains thereafter (Table 2). Age of the cow affected weight at each measurement $(P<0.001)$. Body weights at normal weaning and pre-calving were greatest in cows 4 years of age or older and least in 2 year-old cows $(P<0.001)$. Postpartum weights remained low from calving to breeding but recovered at end of breeding to early weaning levels. In a second model, the variability in cow weights with age was evaluated at a constant BCS. Similar to the unadjusted weights, a linear trend was observed for weights adjusted for age at $\mathrm{BCS}=5.0$ (Figure 1). Previous reports indicated that a BCS of 5.0 at calving and increasing BCS at breeding are important for improved reproductive efficiency in postpartum beef cows (Houghton et al., 1990a,b).

Renquist et al. (2006) monitored weight changes in fall-calving-beef cows at four periods (calving, breeding, weaning and mid-gestation) and reported that growth from 3 to 5 years of age caused differences of 28,46 and $18 \mathrm{~kg}$ weight between 3- and 4-, 3- and 5-, and 4- and 5-yr-old cows, respectively. Other investigators have shown that cow 
weight changed with age, however, the age at which mature body weight was reached and the existence of a subsequent decline in body weight have been subject to debate. Northcutt at al. (1992) and Tennant et al. (2002) showed that maximum weight accretion occurred between ages 5 and 6 years. In contrast, Marlowe and Morrow (1985), Choy et al. (2002) and Renquist et al. (2006) reported that mature BW is attained at 7 to 8 years of age. Furthermore, Northcutt et al. (1992), Tennant et al. (2002) and Renquist et al. (2006) found that cow weight declined after $11 \mathrm{yr}$ of age. The present results agree with the latter studies.

\section{Body condition score (BCS)}

Profiles of BCS followed a similar pattern as BW (Table 2). A quadratic increase in BCS was observed with age and maximum BCS was achieved at $4 \mathrm{yr}$ of age. Periodic fluctuations were observed and BCS peaked prior to calving while nadir BCS occurred after calving in all age groups. Body condition fell by at least one full point from precalving to postpartum followed by a gradual increase at breeding. Maximum BCS was observed in $\geq 5$-yr-old cows at pre-calving, whereas minimum BCS was observed in 2yr-old cows in the postpartum period. Weaning treatment and age by treatment interactions affected $(P<0.001)$ BCS pattern. Early weaned cows had greater BCS than control cows at 3- and 5-years of age, whereas no differences occurred in other age groups (data not shown).

A similar profile in BCS was reported by Renquist et al. (2006) with differences occurring between ages 3 and 4, 4 and 5,5 and 6, 7, and 8 years. They also reported a full point BCS decline across all age groups after calving, as in the present study. The close link between BCS and BW profiles is consistent with previous findings, in which BCS 
reached a plateau at ages 5 (Marlowe and Morrow, 1985), and 6 to 8 yr (Choy et al., 2002), respectively. The finding that weaning can influence BCS at calving is consistent with previous published reports and might provide an alternative management strategy to improve reproductive performance of beef cows. Previous investigators have reported that BCS at calving is the single most important determinant of resumption of ovarian

cyclicity (DeRouen et al., 1994; Spitzer et al., 1995; Morrison et al., 1999). Thus, the additional cost in supplementing cows in low BCS to achieve modest BCS at calving might be saved if a similar objective can be achieved by weaning calves prior to traditional weaning times. Such programs might have significant financial implications to livestock producers.

\section{Rib fat}

Rib fat thickness followed a quadratic trend with cow age (Table $3 ; P<0.001$ ); it was least in 2- and 3-yr-old cows, peaked when cows were 4 yr-old, and declined by $5 \mathrm{yr}$ of age. Weaning treatment and its interactions with age and with period affected $(P<$ 0.006) rib fat thickness. Early weaned cows of at least $4 \mathrm{yr}$ of age had greater $(P<0.001)$ rib fat thickness as opposed to 2- and 3-yr-old cows (data not shown). Because impetus for fat accretion occurs in the later stages of growth, nutrient homeorrhesis in younger cows could have been targeted preferentially to protein accretion (Hornick et al., 2000). Therefore, the impact of early weaning might not be detected by fat scans in this age group. The periodic pattern of rib fat profile followed a similar pattern as those of BCS and weight. Maximum values were observed pre-calving whereas minimum values were observed postpartum in all age groups. The percentage declines in rib fat between pre- 
calving and postpartum periods were $58,62,76,67$ and $61 \%$ for $2-, 3-, 4-, 5-$, and $\geq 6$-yrold cows respectively.

\section{Rump fat}

Rump fat thickness was affected by age, weaning treatment, period and their 2- $(P$ $<0.05)$ and 3-way interactions $(P<0.001)$. The profile for rump fat was nearly identical to that of rib fat. Early weaning increased $(\mathrm{P}<0.001)$ cow rump fat thickness from weaning to pre-calving period and maintained a numerical advantage post calving over the control. This trend was consistent in all age groups except the 2-yr-old cows (Table 4). Thus, rump fat was the only objective measurement with detectable changes across all levels of independent factors. This finding indicates that rump fat might be the most important non-invasive determinant of beef cow energy status. Adjustment of rump fat to an average BCS (5.0) displayed a quadratic trend with least, intermediate, and peak values at 2-, 3-, and 4 yr and later ages, respectively (Figure 2).

Mobilization of adipose tissue is quantitatively a more important source of energy than body protein or liver glycogen (Schroder and Staufeniel, 2006). Consequently, adipose tissue seems suitable to assess energy balance, because the amount of mobilized body fat approximates the energy demand that is required for milk production and maintenance. Several attempts have been made to correct the variability in using BCS as a measure of energy status in beef and dairy cows due to regional and individual score systems. Wagner et al. (1984) and Buskirk et al. (1992) reported that a $38 \mathrm{~kg}$ change in weight was associated with each unit change in BCS. Ferrell and Jenkins (1996) found a change of $51 \mathrm{~kg}$ empty BW per unit BCS, while Tennant et al. (2002) reported that weight adjustments to BCS varied among time periods of the production cycle. These 
variations in weight per unit BCS among studies prompted an examination of alternative approaches in predicting energy status in cattle. An ultrasonic technique has been established to predict carcass quality in beef cattle (Brethour, 1992). A new aspect would be the application of ultrasound as a monitoring tool for nutritive status in herd management. Measurement of rump fat by ultrasound might be an added value compared to other condition scoring systems because of the objectivity and precision associated with the procedure. Repeatability of ultrasound measurements (Brethour, 1992) indicated reliability of ultrasound for predicting energy status in beef cows. The repeatability between consecutive measurements in that study was 0.975 with an absolute difference of $0.72 \mathrm{~mm}$. Robinson et al. (1992) reported an average standard deviation of $0.43 \mathrm{~mm}$ in repeated ultrasound measurements of fat within individual operators, and approximately $1 \mathrm{~mm}$ when comparing measurements between different operators. Because of the 1-mm metering precision of the ultrasound technique, even slight changes in body condition that may not be appreciable using the BCS system can be determined and computed on an individual or herd basis. These data can be related to production variables to evaluate the effects of negative energy balance (Schroder and Staufeniel, 2006).

\section{Reproductive performance}

Reproductive performance was evaluated using calving interval (CI), days from breeding to calving (BCI), and calving pattern. Mean calving interval was 372.4 days, which varied $(P<0.001)$ with year and tended $(P=0.06)$ to be affected by cow age (Table 5), but not by weaning treatment $(P=0.42)$. Relationship of CI (y) to cow age (x) was explained by polynomial fit: $\mathrm{Y}=321.9+11.2 \mathrm{X}+6.3 \mathrm{X}^{2}-4.0 \mathrm{X}^{3}\left(\mathrm{R}^{2}=0.16, P<\right.$ 0.001). Two-year-old cows had the longest calving intervals $(375.4 \pm 1.9 \mathrm{~d})$ while 3 -yr- 
old cows, surprisingly, had the shortest calving intervals $(364.1 \pm 3.3 \mathrm{~d})$. Calving intervals were highly variable in 4-yr-old cows. Calving interval was negatively correlated $(\mathrm{r}=-0.21, P<0.01)$ to rib fat thickness at breeding (Table 6).

Interval from breeding to calving differed $(P<0.001$; Table 5) between 2 - and 3 yr-old cows ( $303.5 \pm 1.6$ vs. $292.5 \pm 2.8$ days, respectively) but not among cows $\geq 4$ yr of age. Relationship of BCI $(y)$ to cow age $(\mathrm{x})$ was explained by polynomial fit: $\mathrm{Y}=280.4$ $+2.9 \mathrm{X}+4.5 \mathrm{X}^{2}-1.8 \mathrm{X}^{3}\left(\mathrm{R}^{2}=0.12, P<0.001\right)$. Interval from breeding to calving was highly, but negatively correlated to pre-partum rump fat ( $\mathrm{r}=-0.27, P<0.001$; Table 6 ) and to BCS at breeding $(\mathrm{r}=-0.27, P<0.001$; Table 6$)$. These relationships were greater $(P<0.001)$ than those of BCI to any of the remaining energy variables at breeding or before calving.

Because adequate reproductive performance is essential to profitability, the effect of age on CI and BCI has a significant impact in beef cattle production. The longer CI and $\mathrm{BCI}$ between the first calving at $2 \mathrm{yr}$-old and calving at $3 \mathrm{yr}$ of age was likely due to increased postpartum anestrous intervals in primiparous cows. Previous researchers have noted an association of age and longer postpartum interval (Neville et al., 1990; Morris et al., 2006; Renquist et al., 2006) and attributed it to postpartum loss of weight and BCS in primiparous cows. The relationships described above and energy profiles described in preceding sections support that hypothesis and indicate that losses in rump fat might be more accurate markers of energy status relevant to longer postpartum intervals than weight or BCS losses. Therefore, preferentially managing younger cows to minimize rib and rump fat losses up to their second calving as 3-yr-olds and subsequent rebreeding might shorten CI and BCI. Dystocia is more common in first-calf heifers and is presumed 
to delay rebreeding by delaying uterine involution (Laster et al., 1973; Bellows and Short, 1978). However, Bridges et al. (2000) found that subsequent pregnancies were more apt to occur in the previously gravid than the previously non-gravid uterine horn, which casts some doubt on that assumption. Although, calving difficulty was not monitored, this might explain the longer CI and BCI in 2-yr-old cows. After 3 years of age, there was little change in calving interval and BCI. These results indicate that once cows calve a second time, the effects of age on reproductive efficiency become minimal. Interactions of age with time of year of calving affected length of calving interval (Ottobre and Lewis, 1983). In that study, cows that calved from December to February had longer calving intervals that those that calved from March to April. Consistent with our findings, the effect was more pronounced in 2- and 3-yr-old cows than in older cows.

Retention pattern in the herd was analyzed by contingency tables as percent cows exposed to breeding that successfully reared a subsequent calf to weaning following the first and second breeding seasons. A total of 314 cows were exposed to breeding. Retention pattern differed $(P<0.05)$ with treatment and age (Table 7), and averaged 55.2 and $66.5 \%$ for control and early-weaned cows, respectively. Cows that did not calve or wean a calf the subsequent year and were eventually culled (Retention pattern $=0$ ) accounted for $28 \%$ of the total observations and were mainly 2-yr-old cows. Cows that calved and weaned a calf the subsequent year, but not the third year $($ Retention pattern $=$ 1) accounted for $42.4 \%$ of total observations and were mainly 2-, and 3-yr-old cows. Lastly, cows that calved and weaned calves after both breeding seasons (Retention pattern $=11)$ accounted for $29.6 \%$ of the total observations and were mainly cows $\geq 4$-yrold. 
Retention in the herd was a function of pregnancy, calving and culling rates. Being pregnant at the end of the breeding season, calving within the designated calving season, and successfully rearing a calf to weaning were requisites for cows to be retained in the herd. Cows were culled from the herd due to other reasons such as still birth, low calf weight at weaning, and poor body condition at breeding. However, these culling decisions were made independent of treatment. Early weaning decreased the proportion of cows culled by 11.3 percentage points or about $25 \%$, from 44.8 to $33.5 \%$. Body condition at breeding was an important factor in cow retention in the subsequent breeding season. Because more control cows exhibited poor condition at breeding, they were subsequently culled from the herd. The high culling pressure practiced at the farm favored cows with greater body condition and might have influenced the differences in persistence among the two treatment groups despite both having similar pregnancy rates at end of breeding. Grings et al. (2005) reported that season of calving and age at weaning affected weight and BCS dynamics of beef cows, but did not change the proportion of cows that became pregnant after natural breeding. However, those authors did not evaluate persistence in their herd and were not able to detect differences due to weaning age or season of calving.

\section{Weaning weights}

Calf weaning weights in the subsequent year were affected by their dams' previous weaning treatment, age, and year $(P<0.001)$. Calves from early-weaned cows were heavier at weaning $(225.2 \pm 3.1 \mathrm{~kg})$ than their contemporaries from control cows $(216.7 \pm 4.1 \mathrm{~kg})$, and from $\geq 4$ yr-old cows than from 2 - and 3-yr-old cows $(P<0.001$; Figure 3). Weaning weights increased in yr 2 by $8 \%$ over yr 1 and might have been 
influenced by increased culling or potentially better management during the study (data not shown). As expected (Richardson et al., 1978; Baker and Boyd 2003), steer calf weights at weaning were greater $(P<0.001)$ than those of heifer calves $(226.4$ vs. 215.5 $\mathrm{kg})$.

The effect of age of the dam on calf weaning weight has been reported (Melton et al., 1967; Vargas et al., 1999; Baker and Boyd, 2003) and might be explained by lower birth weights and milk production in 2-yr-olds. Primiparous cows are usually bred to low birth weight bulls to avoid the effects of dystocia on postpartum intervals. This in turn, lowers birth and weaning weights of their calves. Vargas et al. (1999) attributed low weaning weights of calves from primiparous cows to the latter's small frame size and low body condition. In the current study, energy profiles of 2-yr-old cows were persistently low throughout and were not affected by treatment. This observation confirmed the finding of Vargas et al. (1999) and indicated that while calving ease might be advantageous in beef cattle management, it might limit profitability as it progressively lowered weaning weights in calves. Low milk production in primiparous cows also limited weaning weights of their calves (Melton et al., 1967; Baker and Boyd, 2003). In the latter study, weaning weights of calves from 5- and 6-yr-old cows exceeded those of 2-yr-old cows by about $36 \mathrm{~kg}$ across two genetic lines.

Little is known about the effect of early weaning of cows on subsequent calf weaning weight. Most studies have been directed to its effects on weaning weight of the current calf with minimal attention to birth weight of the subsequent calf. Weaning weight of the subsequent calf is needed to fairly compare the producing ability of the 
cow, because this measure is taken at the end of the period over which she exerts her maximum influence on growth of her calf.

Richardson et al. (1978) reported that weight gained by cows after weaning between 120 and $210 \mathrm{~d}$ postpartum was associated with increased calving difficulty the following year but did not affect weights of the subsequent calves. Pate et al. (1985) evaluated the effects of weaning calves at 8.5 vs. 10.5 mo of age on subsequent cow performance and obtained a $6.6 \mathrm{~kg}$ improvement in weaning weight of the subsequent calves by earlier weaning. That outcome was comparable to the $8.6 \mathrm{~kg}$ difference in the current study. Therefore, an early weaning age can offer significant advantages in cowcalf production that should be of economic importance.

\section{Conclusion}

Early weaning improved energy partitioning and production efficiency in beef cows. The significant effects of age on $\mathrm{BW}, \mathrm{BCS}$, rib and rump fat, $\mathrm{CI}, \mathrm{BCI}$ and calf weaning weights demonstrate the importance that herd age profiles might have on the

profitability of beef cattle enterprises. First and $2^{\text {nd }}$ parity cows should be managed to minimize BW and BCS losses after calving to improve their reproductive efficiency. Discrepancies with utilizing BCS to predict energy status in beef cows might be minimized by ultrasonic measurement of rump fat. Therefore, further research is required to determine its use in nutritional management. 
Table 2: Least squares means $\pm \mathrm{SE}$ of BW and BCS of cows 2 to $\geq 6$ years of age ${ }^{1}$

\begin{tabular}{|c|c|c|c|c|c|c|c|}
\hline Cow age & $\mathbf{n}$ & Early Weaning & Normal Weaning & Precalving & End of Calving & Breeding & End of Breeding \\
\hline \multicolumn{8}{|c|}{$\mathrm{BW}, \mathrm{kg}$} \\
\hline 2 & 175 & $477.0 \pm 4.1 \mathrm{a}$ & $499.0 \pm 4.2 \mathrm{a}$ & $522.6 \pm 4.7 \mathrm{a}$ & $453.1 \pm 4.8 \mathrm{a}$ & $443.4 \pm 7.0 \mathrm{a}$ & $503.5 \pm 5.7 \mathrm{a}$ \\
\hline 3 & 88 & $506.6 \pm 5.8 \mathrm{~b}$ & $532.5 \pm 6.1 \mathrm{~b}$ & $559.3 \pm 7.0 \mathrm{~b}$ & $494.7 \pm 6.8 \mathrm{~b}$ & $509.9 \pm 9.8 \mathrm{~b}$ & $541.3 \pm 8.7 b$ \\
\hline 4 & 28 & $556.2 \pm 10.1 \mathrm{c}$ & $573.7 \pm 10.5 \mathrm{c}$ & $622.7 \pm 21.4 \mathrm{c}$ & $526.4 \pm 11.9 \mathrm{bc}$ & $536.3 \pm 17.4 \mathrm{bc}$ & $589.2 \pm 24.0 \mathrm{bc}$ \\
\hline 5 & 42 & $594.1 \pm 8.5 \mathrm{~d}$ & $612.5 \pm 8.9 \mathrm{~d}$ & $650.3 \pm 9.3 \mathrm{c}$ & $554.6 \pm 10.2 \mathrm{c}$ & $555.6 \pm 14.6 \mathrm{bc}$ & $606.7 \pm 10.5 \mathrm{c}$ \\
\hline$\geq 6$ & 75 & $593.4 \pm 6.0 \mathrm{~d}$ & $614.0 \pm 6.2 \mathrm{~d}$ & $649.8 \pm 7.0 \mathrm{c}$ & $557.2 \pm 7.2 \mathrm{c}$ & $573.4 \pm 10.6 \mathrm{c}$ & $584.7 \pm 8.0 \mathrm{c}$ \\
\hline \multicolumn{8}{|c|}{$\mathrm{BCS}^{2}$} \\
\hline 2 & 175 & $5.4 \pm 0.1 \mathrm{a}$ & $5.6 \pm 0.1 \mathrm{a}$ & $5.5 \pm 0.1 \mathrm{a}$ & $4.6 \pm 0.1 \mathrm{a}$ & $5.0 \pm 0.1 \mathrm{a}$ & $5.6 \pm 0.1 \mathrm{a}$ \\
\hline 3 & 88 & $5.4 \pm 0.1 \mathrm{a}$ & $5.8 \pm 0.1 \mathrm{ab}$ & $5.9 \pm 0.1 \mathrm{~b}$ & $5.0 \pm 0.1 \mathrm{~b}$ & $5.4 \pm 0.1 \mathrm{~b}$ & $5.8 \pm 0.1 \mathrm{ab}$ \\
\hline 4 & 28 & $5.9 \pm 0.1 \mathrm{~b}$ & $6.2 \pm 0.1 \mathrm{~b}$ & $6.0 \pm 0.3 \mathrm{bc}$ & $5.4 \pm 0.1 \mathrm{~b}$ & $5.8 \pm 0.1 \mathrm{c}$ & $5.9 \pm 0.3 \mathrm{ab}$ \\
\hline 5 & 42 & $5.8 \pm 0.1 \mathrm{~b}$ & $6.4 \pm 0.1 \mathrm{~b}$ & $6.3 \pm 0.1 \mathrm{c}$ & $5.1 \pm 0.1 \mathrm{~b}$ & $5.5 \pm 0.1 \mathrm{bc}$ & $6.0 \pm 0.1 \mathrm{~b}$ \\
\hline$\geq 6$ & 75 & $5.8 \pm 0.1 \mathrm{~b}$ & $6.2 \pm 0.1 \mathrm{~b}$ & $6.4 \pm 0.1 \mathrm{c}$ & $5.2 \pm 0.1 \mathrm{~b}$ & $5.5 \pm 0.1 \mathrm{bc}$ & $5.9 \pm 0.1 \mathrm{ab}$ \\
\hline
\end{tabular}

\footnotetext{
${ }^{1}$ Early weaning, Normal weaning, Precalving, End of calving, Breeding and End of breeding were periodic measurements taken in September, October, January, April, and May, respectively.

${ }^{2}$ BCS $(1=$ severely emaciated to $9=$ obese $)$.

LS means \pm SE within columns differed, a vs. b, c, or d $(P<0.001)$.
} 
Table 3: Least squares means \pm SE for rib and rump fat of cows 2 to $\geq 6$ years of age ${ }^{1}$

\begin{tabular}{|c|c|c|c|c|c|c|}
\hline Cow age, yr & $\mathbf{n}$ & Early Weaning & Normal Weaning & Precalving & End of Calving & Breeding \\
\hline \multicolumn{7}{|c|}{ Rib Fat, mm } \\
\hline 2 & 175 & $2.8 \pm 0.2 \mathrm{a}$ & $3.4 \pm 0.2 \mathrm{a}$ & $3.5 \pm 0.2 \mathrm{a}$ & $1.6 \pm 0.1 \mathrm{a}$ & $1.9 \pm 0.1 \mathrm{a}$ \\
\hline 3 & 88 & $2.9 \pm 0.2 \mathrm{a}$ & $4.4 \pm 0.3 \mathrm{~b}$ & $5.3 \pm 0.4 \mathrm{~b}$ & $2.0 \pm 0.2 \mathrm{ab}$ & $2.4 \pm 0.2 \mathrm{ab}$ \\
\hline 4 & 28 & $5.4 \pm 0.4 \mathrm{c}$ & $7.6 \pm 0.5 \mathrm{~d}$ & $11.3 \pm 1.1 \mathrm{~d}$ & $2.5 \pm 0.3 \mathrm{bc}$ & $2.7 \pm 0.3 \mathrm{bc}$ \\
\hline 5 & 42 & $3.9 \pm 0.3 b$ & $6.0 \pm 0.4 \mathrm{~cd}$ & $6.9 \pm 0.5 \mathrm{c}$ & $2.9 \pm 0.2 \mathrm{c}$ & $3.0 \pm 0.2 \mathrm{c}$ \\
\hline$\geq 6$ & 75 & $3.1 \pm 0.3 \mathrm{ab}$ & $5.3 \pm 0.3 \mathrm{bc}$ & $6.9 \pm 0.4 \mathrm{c}$ & $2.6 \pm 0.2 \mathrm{c}$ & $2.9 \pm 0.28 \mathrm{c}$ \\
\hline \multicolumn{7}{|c|}{ Rump Fat, mm } \\
\hline 2 & 175 & $4.0 \pm 0.3 \mathrm{a}$ & $5.0 \pm 0.4 \mathrm{a}$ & $4.6 \pm 0.3 \mathrm{a}$ & $1.4 \pm 0.2 \mathrm{a}$ & $1.9 \pm 0.2 \mathrm{a}$ \\
\hline 3 & 88 & $4.1 \pm 0.4 \mathrm{ab}$ & $6.5 \pm 0.5 \mathrm{a}$ & $7.1 \pm 0.5 \mathrm{~b}$ & $2.1 \pm 0.2 \mathrm{~b}$ & $2.7 \pm 0.3 \mathrm{ab}$ \\
\hline 4 & 28 & $6.7 \pm 0.7 \mathrm{c}$ & $9.8 \pm 0.9 \mathrm{~b}$ & $10.7 \pm 1.6 \mathrm{bc}$ & $3.0 \pm 0.4 \mathrm{bc}$ & $3.3 \pm 0.5 \mathrm{bc}$ \\
\hline 5 & 42 & $6.5 \pm 0.7 \mathrm{c}$ & $9.3 \pm 0.7 \mathrm{~b}$ & $9.5 \pm 0.7 \mathrm{c}$ & $3.4 \pm 0.3 \mathrm{c}$ & $4.1 \pm 0.4 \mathrm{c}$ \\
\hline$\geq 6$ & 75 & $5.3 \pm 0.5 \mathrm{bc}$ & $8.7 \pm 0.6 \mathrm{~b}$ & $10.2 \pm 0.5 \mathrm{c}$ & $3.3 \pm 0.2 \mathrm{c}$ & $4.0 \pm 0.3 \mathrm{c}$ \\
\hline
\end{tabular}

\footnotetext{
${ }^{1}$ Early weaning, Normal weaning, Precalving, End of calving, Breeding and End of breeding were periodic measurements taken in September, October, January, April, and May, respectively.

LS means \pm SE within columns differed, a vs. b, c, or d $(P<0.001)$.
} 
Table 4: Least squares means \pm SE rump fat $(\mathrm{mm})$ for age by treatment and by period ${ }^{1}$

\begin{tabular}{cccccccccccc} 
& & \multicolumn{2}{c}{ Early Weaning } & \multicolumn{2}{c}{ Normal Weaning } & \multicolumn{2}{c}{ Pre-calving } & \multicolumn{2}{c}{ Postpartum } & \multicolumn{2}{c}{ Breeding } \\
Age & $\mathbf{n}$ & Control & EW & Control & EW & Control & EW & Control & EW & Control & EW \\
\hline 2 & 175 & $4.2 \pm 0.4$ & $3.8 \pm 0.3$ & $4.6 \pm 0.4$ & $5.4 \pm 0.3^{*}$ & $4.2 \pm 0.4$ & $5.1 \pm 0.3$ & $1.5 \pm 0.4$ & $1.5 \pm 0.3$ & $2.1 \pm 0.4$ & $2.0 \pm 0.3$ \\
3 & 88 & $5.1 \pm 0.6$ & $4.8 \pm 0.4$ & $6.0 \pm 0.6$ & $8.0 \pm 0.4^{* *}$ & $6.9 \pm 0.6$ & $8.0 \pm 0.4^{*}$ & $1.7 \pm 0.6$ & $2.2 \pm 0.4$ & $2.5 \pm 0.6$ & $3.0 \pm 0.5$ \\
4 & 28 & $5.0 \pm 0.9$ & $7.6 \pm 0.9^{*}$ & $6.8 \pm 0.9$ & $13.4 \pm 0.9^{* *}$ & $6.4 \pm 1.7$ & $12.6 \pm 1.0^{* *}$ & $1.9 \pm 0.9$ & $4.1 \pm 0.9^{*}$ & $2.0 \pm 1.0$ & $4.2 \pm 0.9^{*}$ \\
5 & 42 & $4.2 \pm 1.1$ & $6.3 \pm 0.6^{*}$ & $4.9 \pm 1.1$ & $10.1 \pm 0.6^{* *}$ & $6.6 \pm 1.1$ & $10.3 \pm 0.6^{* *}$ & $2.0 \pm 1.2$ & $3.4 \pm 0.6$ & $2.6 \pm 1.2$ & $4.3 \pm 0.6$ \\
26 & 75 & $5.3 \pm 0.7$ & $5.8 \pm 0.5$ & $5.8 \pm 0.7$ & $10.5 \pm 0.5^{* *}$ & $7.9 \pm 0.7$ & $12.0 \pm 0.5^{* *}$ & $2.8 \pm 0.7$ & $3.8 \pm 0.5$ & $3.9 \pm 0.8$ & $4.5 \pm 0.5$ \\
\hline
\end{tabular}

\footnotetext{
${ }^{1}$ Early weaning, normal weaning, precalving, end of calving, and breeding are periodic measurements taken in September, October, January, April, and May, respectively.

* LS means \pm SE among treatments within periods differed, $(P<0.05)$.

** LS means \pm SE among treatments within periods differed, $(P<0.01)$.
} 
Table 5: Least squares means \pm SE calving intervals (CI) and breeding to calving interval (BCI) of cows with age, year and treatment ${ }^{1}$

\begin{tabular}{cccc}
\hline \hline Age & $\mathbf{n}$ & $\mathbf{C I}^{2}$ & BCI $^{3}$ \\
2 & 143 & $375.4 \pm 1.9 \mathrm{a}$ & $303.5 \pm 1.6 \mathrm{a}$ \\
3 & 68 & $364.1 \pm 3.3 \mathrm{~b}$ & $292.5 \pm 2.8 \mathrm{~b}$ \\
4 & 6 & $373.5 \pm 8.4 \mathrm{ab}$ & $286.8 \pm 6.4 \mathrm{ab}$ \\
5 & 38 & $373.7 \pm 3.2 \mathrm{ab}$ & $297.9 \pm 2.8 \mathrm{ab}$ \\
$\geq 6$ & 59 & $372.3 \pm 2.5 \mathrm{ab}$ & $298.5 \pm 2.1 \mathrm{ab}$ \\
Year & 159 & $378.3 \pm 2.5 \mathrm{a}$ & $297.4 \pm 2.0$ \\
$2005-2006$ & 155 & $365.2 \pm 2.5 \mathrm{~b}$ & $294.3 \pm 2.0$ \\
$2006-2007$ & 96 & $372.9 \pm 2.8$ & $295.6 \pm 2.3$ \\
Treatment & 218 & $370.7 \pm 2.1$ & $296.1 \pm 1.6$ \\
Control & & & \\
Early Weaned & & & \\
\hline
\end{tabular}

${ }^{1}$ a vs. b, LS means within columns different $(P<0.05)$

${ }^{2} \mathrm{CI}$ : number of days from previous calving to next calving

${ }^{3} \mathrm{BCI}$ : number of days from start of breeding to next calving. 
Table 6: Pairwise correlations of beef cow energy variables at selected periods with reproductive variables ${ }^{1}$

Calving interval, $\mathrm{d}$

\begin{tabular}{llccc}
\hline \multicolumn{1}{c}{ Variable } & $\mathrm{n}$ & Pre-calving & $\mathrm{n}$ & Breeding \\
\hline BCS & 145 & $-0.02 \mathrm{~ns}$ & 144 & $-0.09 \mathrm{~ns}$ \\
Rib fat & 154 & $-0.05 \mathrm{~ns}$ & 155 & $-0.21^{* *}$ \\
Rump fat & 153 & $-0.11 \mathrm{~ns}$ & 155 & $-0.12 \mathrm{~ns}$ \\
Weight & 155 & $-0.09 \mathrm{~ns}$ & 155 & $-0.07 \mathrm{~ns}$ \\
& Interval from breeding to calving, d & \\
BCS & 159 & $-0.17^{*}$ & 158 & $-0.27^{* * *}$ \\
Rib fat & 168 & $-0.25^{* *}$ & 169 & $-0.23^{* *}$ \\
Rump fat & 166 & $-0.27^{* * *}$ & 169 & $-0.22^{* *}$ \\
Weight & 169 & $-0.18^{*}$ & 169 & $-0.21^{* *}$ \\
\hline
\end{tabular}

$1 * P<0.05$

$* * P<0.01$

$* * * P<0.001$

n.s. non significant. 
Table 7: Comparison of retention pattern (\%) among cow age groups during the study

\section{Retention Pattern ${ }^{1}$}

\begin{tabular}{lllll} 
Age & $\mathbf{n}$ & $\mathbf{0}$ & $\mathbf{1}$ & $\mathbf{1 1}$ \\
\hline 2 & 143 & 41.3 & 45.5 & 13.2 \\
3 & 68 & 8.8 & 61.8 & 29.4 \\
$4 \& 5$ & 44 & 31.8 & 20.5 & 47.7 \\
$\geq 6$ & 59 & 15.3 & 28.8 & 55.9 \\
\hline
\end{tabular}

${ }^{1}$ Retention pattern 0 : Cows that did not wean a subsequent calf during the study period.

Retention pattern 1: Cows that weaned a calf once during the study.

Retention pattern 11: Cows weaned calves in both subsequent years of study. 


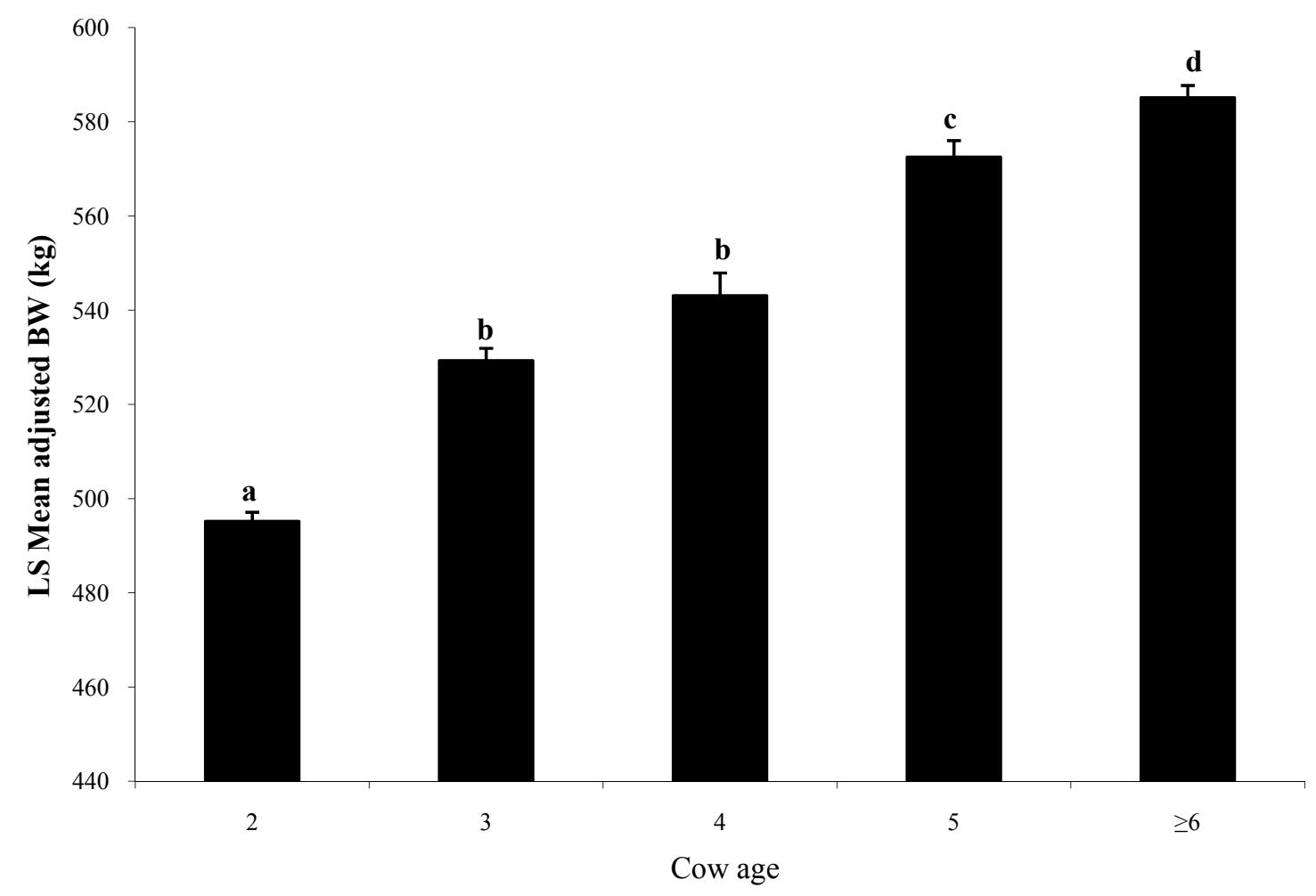

Figure 1: Least squares means $( \pm \mathrm{SE})$ for cow weight $(\mathrm{kg})$ adjusted to average body condition score $(\mathrm{BCS}=5.0)$ for every age category.

a,b, c, d LS means without common superscripts differ $(P<0.0001)$.

$\mathrm{n}=175,88,28,42$, and 75 for $2,3,4,5$, and $\geq 6$ - yr-old cows respectively. 


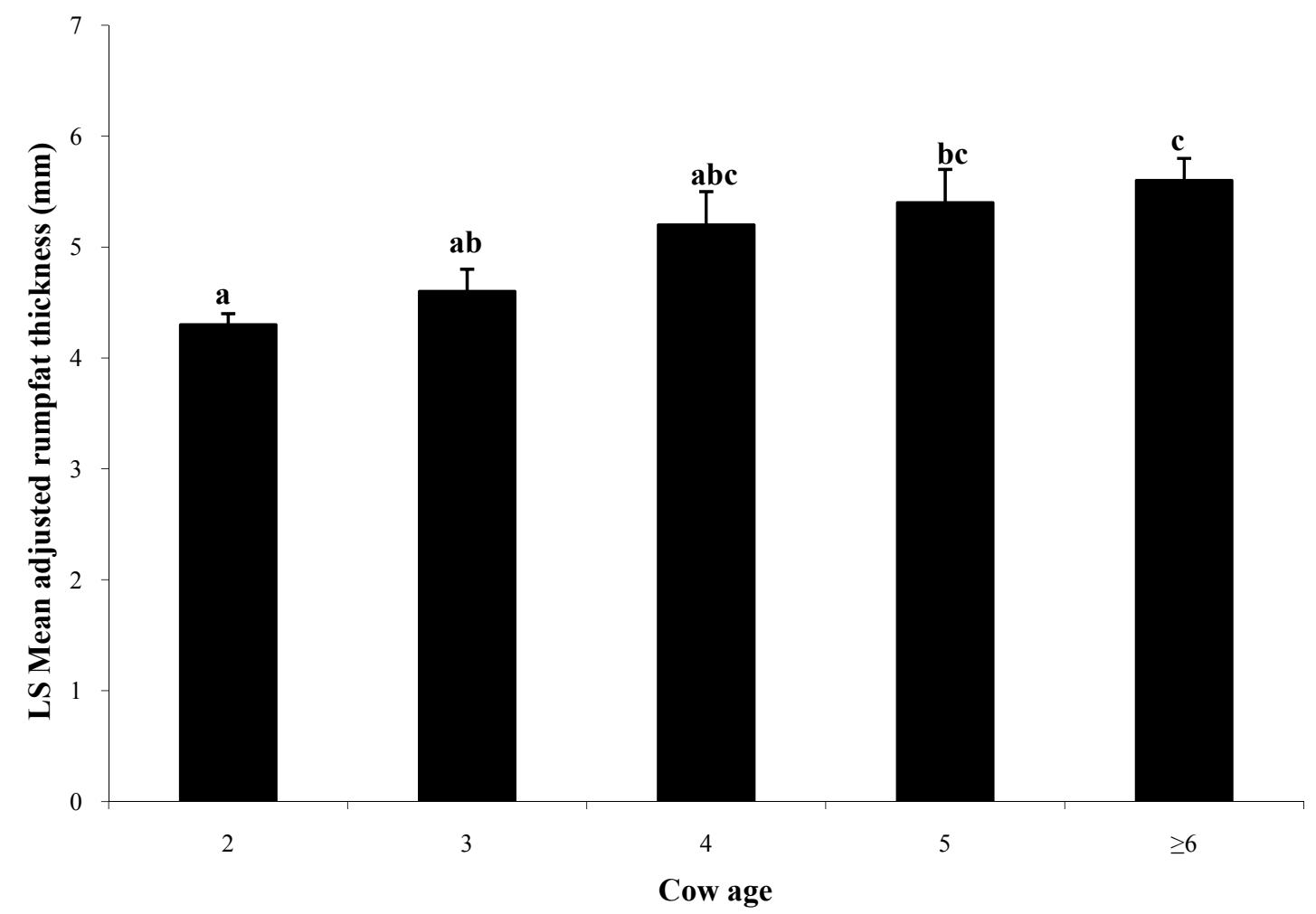

Figure 2: Least squares means $( \pm \mathrm{SE})$ for cow rump $(\mathrm{mm})$ fat thickness adjusted to average body condition score $(\mathrm{BCS}=5.0)$ for every age category. ${ }^{\mathrm{a}, \mathrm{b}, \mathrm{c}, \mathrm{d}}$ LS means without common superscripts $\operatorname{differ}(P<0.0001)$. $\mathrm{n}=175,88,28,42$, and 75 for $2,3,4,5$, and $\geq 6$ - yr-old cows respectively. 


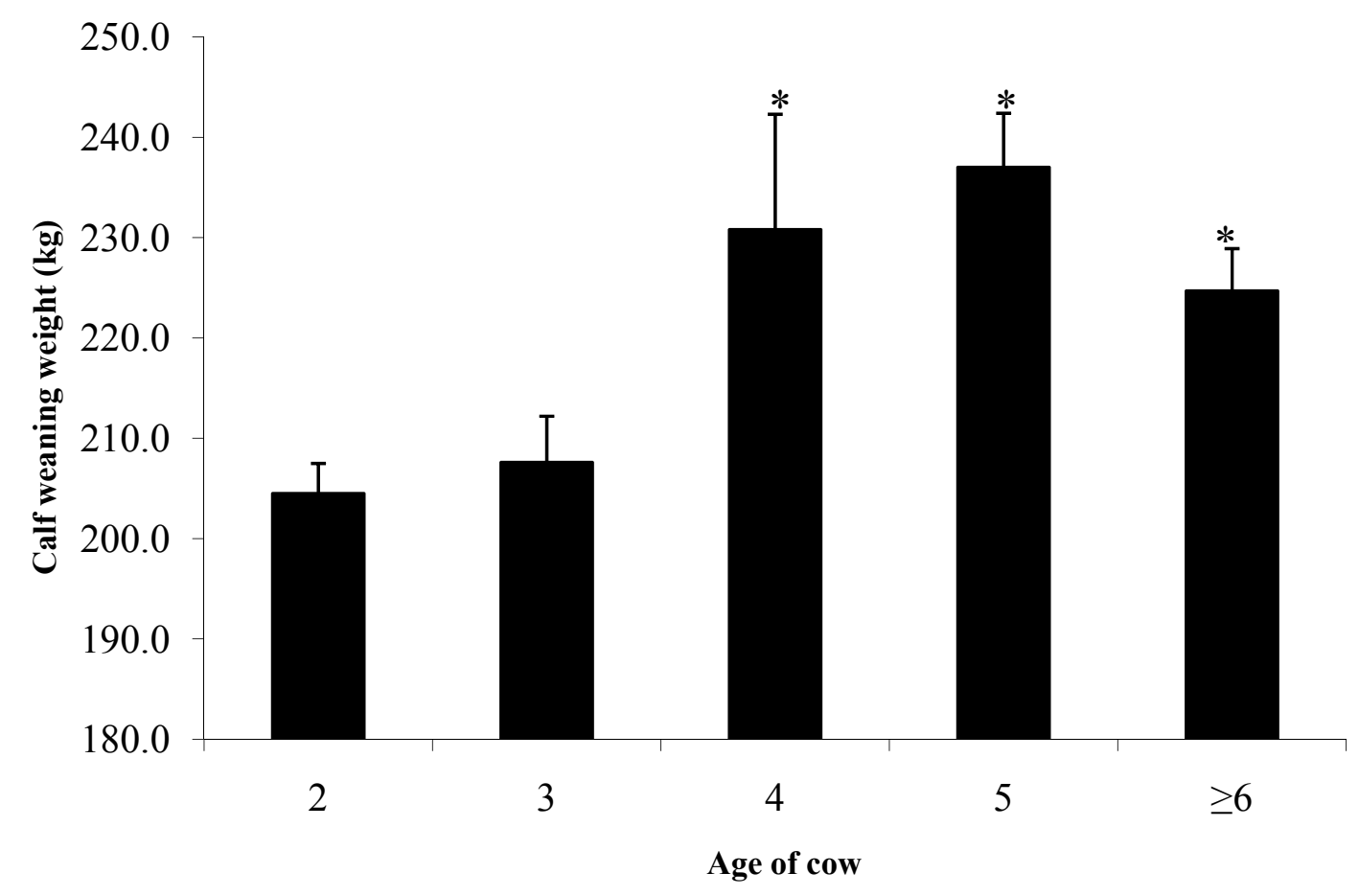

Figure 3: Least squares means $\pm \mathrm{SE}$ for calf adjusted 205-d weaning weights $(\mathrm{kg})$ by cow age.

*Weaning weights increased $(P<0.0001)$ in calves from cows $\geq 4$ yr of age. $\mathrm{n}=106,58,20,26$, and 42 for $2,3,4,5$, and $\geq 6$ - yr-old cows respectively. 


\section{Experiment 2: Pregnancy outcome in dairy and beef cattle after artificial insemination with adjunctive seminal plasma or transforming growth factor beta-1}

\section{Introduction}

The role of post-mating inflammatory response and whether or how it may impact pregnancy success is not clear. Exposure of the uterine lumen and tissue to seminal plasma induces a cascade of cellular and molecular events characteristic of an inflammatory response (Robertson et al. 1996; O’Leary et al., 2004). Most prevalent of these are infiltrations of macrophages and MHC class II+ cells into the endometrium, and granulocytes into the luminal fluid (O'Leary et al., 2004). This inflammatory reaction to semen was observed first in rabbits but has since been described in several other species (Fahmi et al., 1985; Robertson, 2007a). Although inflammatory response dissipates by the time the embryo is implanted (O'Leary et al., 2004; Robertson, 2007a), exposure to seminal fluids could proactively influence subsequent events in the female tract to promote conception and progression of pregnancy (Robertson et al., 2006; Robertson, 2007a). Studies in rodents (Pang et al., 1979; Queen et al., 1981) provided compelling evidence that seminal fluid influenced sperm survival and competence and that absence of seminal fluid at mating resulted in impaired fertility and/or reduced fertilization. In golden hamsters, slower cleavage rates during embryonic development and increased embryonic losses were reported following mating with males that had their accessory sex glands removed surgically (O et al., 1988; Chow et al., 2003).

Pro-inflammatory signals in the seminal fluid have been associated with sperm and/or seminal plasma depending on animal species (Bischof et al., 1994; Rozeboom et al., 1999; O'Leary et al., 2004). Transforming growth factor (TGF)- $\beta 1$, which is abundant 
in seminal plasma, was identified as the active inflammatory-inducing moiety derived from the seminal vesicles (Tremellen et al., 1998; Robertson et al., 2002), and likely accounts largely for the immunosuppressive activity of seminal plasma. Because seminal antigens are shared with the conceptus, seminal TGF- $\beta 1$ may act to facilitate induction of maternal immune tolerance to conceptus antigens and thereby promote implantation success. Perturbations in concentrations of TGF- $\beta 1$ might, in some instances, be insufficient or inappropriate for immune adaptation leading to implantation failure or other pathologies of pregnancy (Von Linsigen et al., 2005).

Strategies that incorporate immuno-stimulatory molecules at artificial insemination might improve reproductive efficiency in domestic ruminants. For example, intrauterine infusion with seminal and sperm antigens prior to breeding increased litter size in pigs (Murray et al., 1983). However, a recent study failed to elicit a beneficial effect of recombinant TGF- $\beta 1$ administered at artificial insemination on total or live implantation rate at day 80 of pregnancy in gilts (Rhodes et al., 2006). Subsequent review of that work by Robertson et al. (2006) indicated that it did not have enough statistical power to detect small changes in litter size expected on the basis of previous studies with seminal plasma.

Few well-designed studies have evaluated seminal fluid exposure on pregnancy outcome in domestic animals. The objective of the current study was to extend the developing hypothesis to dairy and beef cattle by examining the influence of presensitization, before or at breeding, of the uterus with seminal antigens on pregnancy outcome. Thus, the null hypothesis was that treatment of cows and heifers with 
intrauterine deposition of TGF $\beta-1$ will not improve pregnancy outcome more than treatment with seminal plasma.

\section{Materials and methods}

\section{Animals}

Beef cows $(n=1090)$ in herds at three locations at West Virginia University, in a commercial herd in West Virginia, and in a herd in Montana were used during May through July each year from 2003 to 2006. Hereford, Angus and their crosses were the predominant breed compositions in all herds. Cows ranged from yearling heifers to 7-yrold at treatment and averaged about four years of age. Cows used in more than one year were reassigned at random among treatments in the subsequent year. Lactating Holstein dairy cows $(n=800)$ in 8 commercial herds located in Ohio or western Pennsylvania were used in the study. Neither technician nor bulls were restricted except that only semen from three dairy sires of known fertility (average) was used in the dairy herds. Dairy cows were inseminated artificially between fall (November) 2005 and spring (March) 2006. All procedures were performed with the approval of the West Virginia University Animal Care and Use Committee (ACUC No. 05-1104).

\section{Experimental protocol}

\section{Estrus synchrony}

Beef cows were synchronized for estrous activity and thereafter assigned randomly among treatments. Estrus was synchronized using a seven-day progesterone $\operatorname{CIDR}^{\circledR}$ (EAZI-BREED ${ }^{\mathrm{TM}}$, DEC International, Hamilton, New Zealand) insert followed by 25 mg PGF2 $\alpha$ (Pharmacia Animal Health, Pfizer, Inc., Kalamazoo, MI) at CIDR ${ }^{\circledR}$

removal. A subset of cows in 2004 were synchronized to allow for timed artificial 
insemination by including administration of estradiol cypionate and progesterone at CIDR $^{\circledR}$ insertion and administration of estradiol cypionate 24 hours after CIDR $^{\circledR}$ removal. Timed insemination was approximately 30 hours after CIDR $^{\circledR}$ removal. Heifers in the same period were synchronized by a modified version of the first protocol that included administration of estradiol benzoate 18 hours post CIDR $^{\circledR}$ removal and timed breeding at 30 hours.

\section{Treatments}

Treatments were prepared and packaged in $0.5 \mathrm{~mL}$ bovine insemination straws by Select Sires, Inc. (Plain City, OH). Color-coded straws contained either $0.5 \mathrm{ml}$ seminal plasma (SP), $40 \mathrm{ng} / 0.5 \mathrm{ml}$ recombinant human transforming growth factor- $\beta 1$ (rh-TGF$\beta 1$, Sigma-Aldrich, St Louis, MO) suspended in bovine serum albumin (BSA, SigmaAldrich, St Louis, MO), or $0.5 \mathrm{ml} \mathrm{BSA}$. For the beef cow trials, SP was collected by artificial vagina from a single vasectomized bull, which had a pre-surgery history of average fertility. In the dairy cow trial, SP was obtained from a heterogeneous mixture of seminal plasma aspirated from ejaculates of 6 mature Holstein sires of average or better fertility following centrifugation of ejaculates at approximately $1000 \times \mathrm{g}$ for 10 minutes. In both studies, seminal plasma was extruded through a 0.45 micron capsule filter. The straws were frozen and stored in liquid nitrogen. Artificial insemination technicians were blind to treatment codes. At treatment, straws were thawed, loaded into insemination guns, and delivered into the uterus by normal artificial insemination procedures.

\section{Artificial insemination}


In 2003 and 2004, treatments were administered to beef cows at the onset of estrus with inseminations at 12 hours (AM-PM rule) after treatments. In timed-bred animals, treatments were administered 12 hours before insemination. In subsequent trials (2005 and 2006, beef and dairy cows), treatments were administered at insemination. In that case, treatment was administered first and then semen was deposited using a second insemination gun. The target site of deposition for both treatment and semen was the uterine body immediately anterior to the internal cervical os. Pregnancy diagnosis was performed 35 to 40 days after insemination using transrectal ultrasonic imaging (Aloka America, Willingford, CT) or palpated per rectum in West Virginia herds and the dairy herds. Pregnancy data for Montana cattle were extrapolated from calving records in subsequent calving seasons.

\section{Statistical analysis}

Data for beef and dairy cows were analyzed separately by least squares analysis of variance using the GLM procedures of SAS (SAS Institute, Cary, NC). Fixed effects in the beef cow model included: herd, treatment, time of treatment $(12 \mathrm{~h}$ before insemination or at insemination), age of the cow, year of study and their second and third order interactions. Fixed effects in the dairy cow model included: location, treatment, parity (primiparous vs. multiparous), post-partum interval, sire and their second and third order interactions. A Chi square model was used in the final analysis after removal of non-significant interactions. Values were declared significant at $\alpha=0.05$ unless stated otherwise.

\section{Results}

Beef Cows 
Neither timed breeding versus breeding after estrus, age of the cow, nor geographic location differentially affected the responses $(P>0.05)$. Therefore, data were combined and evaluated for the effects of treatments and trials. Pregnancy outcomes were similar among treatments but differed $(P<0.05)$ among trials (Table 8). Overall pregnancy rates were $53.1 \pm 5.3,54.7 \pm 5.3$, and $54.8 \pm 5.9 \%$ for BSA, SP and TGF $\beta 1$, respectively. A gradual decline in pregnancy rates from $69.8 \pm 6.7,52.5 \pm 5.3$, to $40.3 \pm$ 4.6\% was observed among trials 1, 2 and 3 that corresponded to years 2003-2005, respectively. There was a tendency $(P<0.07)$ for an effect of treatments within trials. TGF- $\beta 1$ treatment increased pregnancy rates when overall fertility was compromised in trial 3 (Trial 3; Table 8).

In succeeding trials, TGF $\beta 1$ (trial 4) and BSA (trial 5) were excluded from the treatments. Pregnancy rates did not differ $(P>0.05)$ and averaged $59.4 \pm 4.8$ and $67.0 \pm$ $4.8 \%$ for BSA and SP, respectively (Trial 4; Table 9). In the subsequent trial (5), pregnancy rates were numerically higher in cows treated with seminal plasma than control cows. Average pregnancy rates were $61.4 \pm 5.6$ vs. $52.4 \pm 5.2 \%$ for SP and control, respectively (Trial 5; Table 9).

\section{Dairy Cows}

Pregnancy rates in dairy cows were generally lower than those observed in beef cows $(36.6 \%$ versus $54.2 \%)$. Treatment with seminal plasma or TGF $\beta-1$ had no $(P>$ 0.05 ) significant effect but numerically increased pregnancy rates by about $10 \%$ over control (Trial 6;Table 9).

\section{Discussion}


These studies were designed to evaluate the presumed effect of inducing a postmating inflammatory response by treatment with seminal plasma or TGF $\beta-1$ on pregnancy outcome in lactating beef and dairy cattle. Under natural conditions, mating occurs at estrus whereas ovulation occurs 12 hours after onset of estrus. Therefore, the female genital tract is exposed to seminal fluids and would probably initiate an inflammatory response long before ovulation and fertilization. An inflammatory reaction was detected within 30 minutes post insemination in mares (Katila, 1996). Scott et al. (2005) reported peak concentrations of neutrophils at 6-18 hours and macrophages at 1824 hours in the posterior cervix and uterine lumen of ewes after mating. Leukocyte infiltration into the endometrium of sows occurred within hours after mating (Bischof et al., 1994; Rozeboom et al., 1998).

The post insemination inflammatory reaction in the cow has not been thoroughly studied. In addition, there does not appear to be a study on the effects of seminal plasma proteins on modulating this inflammatory response in cattle. Therefore, the initial studies were designed to mimic natural conditions by delivering treatments at the onset of estrus and allowing time for initiation of the inflammatory response before insemination. Treatments with TGF- $\beta 1$ or seminal plasma were expected to provide a counter-active response to the inflammatory reaction and allow for fertilization and progression of pregnancy. The data provided no statistical evidence for an effect of any of the treatments examined on pregnancy outcome. Although seminal plasma TGF- $\beta 1$ had been suggested to play a sperm-protecting role in the female reproductive tract of other species (Tremellen et al., 1998; Robertson et al., 2002), the current study was unable to conclusively determine that role at least in the bovid. A recent study also failed to find 
any beneficial effect of recombinant TGF- $\beta 1$ administered at AI on total or live implantation rate at d 80 of pregnancy, however, placental efficiency (mass of fetus/mass of placenta) was improved in pregnancies established in gilts treated with TGF- $\beta 1$ (Rhodes et al., 2006). This lack of effect of TGF- $\beta 1$ might have occurred due to lack of concurrent activity of several synergizing and inhibitory cofactors regulated by other receptor signaling pathways. It has been noted that the presence of other cytokines drive the actions of TGF- $\beta 1$ (Letterio and Roberts, 1998).

Although not statistically significant, inseminations with adjunctive seminal plasma provided numerically greater pregnancy rates consistently over other treatments overall. However, the exact nature of how this effect was achieved remains to be identified. It was reported at least in the gilt, that seminal plasma enhanced the rate of disappearance of uterine inflammation following breeding by suppressing leukocyte (polymorphonuclear neutrophiles (PMN)) migration into the uterus (Rozeboom et al., 1999). In mares stimulated to develop uterine inflammation prior to breeding, seminal plasma reduced sperm-leukocyte (PMN) binding indicating an important spermprotecting role of seminal plasma (Alghamdi et al., 2004). Alternatively, seminal plasma might have trophic effects on the embryo that culminate in increased pregnancy rates. The impact of seminal plasma on embryonic development might occur through secretion of embryotrophic factors in response to changes in the endometrial tissue or altered immune environment. Prior exposure of pig uteri to seminal plasma altered the uterine environment and ultimately increased embryonic viability and growth (Murray et al., 1983; O’Leary et al., 2004). A principal cytokine, GM-CSF has been shown to promote 
viability of the pre-implanted embryo by inhibiting apoptosis and regulating glucose uptake (Robertson et al., 2001; Robertson, 2007b).

Increased milk yield has contributed to the historical decline in fertility of lactating dairy cows despite adequate fertilization rates and controlled preovulatory follicular development. Increased embryonic losses due to retarded development or failure of attachment might explain this decline in fertility (Dailey et al., 2002). Certain strategies for increasing fertility in dairy cows have already been examined. These include manipulation of the somatotropin-insulin-like growth factor 1 axis (Moreira et al., 2000, 2001; Starbuck et al., 2006), and use of embryo transfer to bypass the effects of heat stress on oocyte function and early embryonic development (Block and Hansen, 2007). Pregnancy rates of lactating dairy cows were increased by addition of recombinant bovine somatotropin (rbST) to the Ovsync protocol (Moreira et al., 2000). This effect of rbST on dairy cow fertility might have occurred through its effects on oocyte maturation, embryonic development, and/or altered oviduct/uterine functions (Moreira et al., 2001). Starbuck et al. (2006) reported enhanced pregnancy in dairy cows treated with a single dose of rbST at insemination. The effect was observed specifically in high producing cows that were $>100$ days in milk. In heat-stressed lactating cows, transfer of in vitro produced embryos that were cultured with IGF-1 increased pregnancy and calving rates. However, beneficial action of IGF-1 on embryo survival was dependent upon heat stress in recipient cows (Block and Hansen, 2007). Strategies that incorporate immunostimulatory molecules at artificial insemination might improve reproductive efficiency in dairy cattle. In pigs these strategies have yielded mixed results. 
In conclusion, the data presented did not provide any conclusive evidence for the overall effect of either TGF $\beta-1$ or seminal plasma to influence pregnancy outcome in lactating beef and dairy cattle. However, the numerical advantage provided by inseminations with adjunctive seminal plasma and/or TGF- $\beta 1$ on pregnancy rates in dairy cattle require further evaluation or might inspire future studies to increase our understanding of how this might affect and enhance fertility in dairy cows. 
Table 8: Least squares \pm SE mean pregnancy rates for beef cattle inseminations evaluating the effects of TGF- $\beta 1$, SP and BSA treatments on pregnancy outcome ${ }^{1}$

\begin{tabular}{lllll}
\hline \hline Trial & BSA & SP & TGF $\beta 1$ & Mean Pregnancy \\
\hline & $\mathrm{n}=267$ & $\mathrm{n}=296$ & $\mathrm{n}=200$ & \\
1 & $60.7 \pm 11.2$ & $78.1 \pm 11.2$ & $70.6 \pm 11.2$ & $69.8 \pm 6.7 \mathrm{a}$ \\
2 & $60.0 \pm 7.9$ & $52.9 \pm 7.9$ & $44.6 \pm 11.2$ & $52.5 \pm 5.3 \mathrm{ab}$ \\
3 & $38.4 \pm 7.9$ & $33.1 \pm 7.9$ & $49.2 \pm 7.9 \dagger$ & $40.3 \pm 4.6 \mathrm{~b}$ \\
Average & $53.1 \pm 5.3$ & $54.7 \pm 5.3$ & $54.8 \pm 5.9$ & \\
\end{tabular}

${ }^{1}$ Treatments were administered 12 hours before insemination in trials 1 and 2 , and at 0 hours in trial 3 following estrous synchronization with $\mathrm{CIDR}^{\circledR}$ and $\mathrm{PGF}_{2 \alpha}$. Pregnancy diagnosis was performed at 35-40 days post insemination in West Virginia herds. Records were kept of calves born in Montana herds.

$\dagger$ Treatment within trial tended to differ $(P=0.07)$.

Least squares means \pm SE differed between years, a vs. $\mathrm{b}(P<0.05)$. 
Table 9: Comparison of pregnancy rates (\%) among studies in beef and dairy cattle

\begin{tabular}{|c|c|c|c|c|c|c|}
\hline \multirow[b]{2}{*}{ Trial } & \multirow[b]{2}{*}{$\mathbf{N}$} & \multicolumn{3}{|c|}{ Treatments } & \multicolumn{2}{|c|}{ \% Increase/Decrease } \\
\hline & & Control & SP & TGF- $\beta 1$ & SP & TGF- $\beta 1$ \\
\hline $1-3^{\mathrm{a}}$ & 763 & 55.1 & 58.8 & 51.0 & 6.7 & -7.1 \\
\hline $4^{\mathrm{a}}$ & 206 & 59.5 & 67.0 & . & 12.6 & . \\
\hline $5^{b}$ & 167 & 52.4 & 61.4 & . & 17.2 & . \\
\hline $6^{\mathrm{bc}}$ & 800 & 33.2 & 37.8 & 36.3 & 13.9 & 9.4 \\
\hline
\end{tabular}

${ }^{\mathrm{a}}$ Control $=$ Treated with $0.5 \mathrm{ml}$ BSA before artificial insemination.

${ }^{\mathrm{b}}$ Control $=$ Left untreated during artificial insemination.

${ }^{\mathrm{c}}$ Dairy cattle study. 


\section{Experiment 3: Analysis of seminal plasma proteins in cryopreserved semen Introduction}

Secretions from the accessory sex glands are mixed with sperm at ejaculation and contribute to the majority of semen volume and components. However, during cryopreservation, most seminal plasma is replaced with semen extenders, mainly egg yolk or milk proteins. Seminal fluid contains signaling agents that influence female reproductive physiology to improve chances of conception and pregnancy success. These factors include cytokines, sex hormones and prostaglandins (Robertson, 2007). Experiments in rodents and pigs show that seminal plasma is the second most vital component of the ejaculate, absence of which at mating reduced fertilization and increased fetal loss after implantation (O et al, 1998). High concentrations of TGF- $\beta$ cytokines have been detected in boar seminal fluid (O'Leary et al., 2002) and their characteristic immunosuppressive activity was associated with protein fractions of appropriate size in boar seminal fluid (Claus, 1990 reviewed by Robertson, 2007). In the preceding study (Exp. 2), artificial inseminations with adjunctive seminal plasma consistently tended to have little or no effect on pregnancy outcome. The precise nature of active constituents that might influence pregnancy and their relative amounts remain unknown. However, four proteins (osteopontin, spermadhesin Z13, bovine seminal plasma protein (BSP) $30 \mathrm{kDa}$ and phospholipase $\mathrm{A}_{2}$ ) have been identified as markers of fertility in dairy bulls (Moura et al., 2006; 2007). In those studies, Moura et al. (2006; 2007) visualized proteins with Coomassie brilliant blue staining after 2-D gel separation, which may not reveal some of the low abundance proteins that might be present in seminal plasma. 
Therefore, a broader approach was instituted to identify seminal plasma proteins using more sensitive protein detection techniques. These included 2-D fluorescence difference gel electrophoresis (2-D DIGE) and enzyme linked immunosorbent assays (ELISA) that were expected to broaden the number of markers included in the assay and grant more robust predictions of biomarkers for bull fertility. The objectives of this study included 1) large scale identification and differential expression of seminal plasma proteins between high and low fertility bulls, 2) correlation of expression of specific proteins to fertility phenotype, and 3) comparison of the expression patterns pre- and post-cryopreservation.

\section{Materials and methods}

Semen samples were obtained from Select Sires Inc. (Plain City, Ohio) from 16 dairy bulls. Samples were assigned to two groups based on assigned fertility score expressed as the percentage point deviation (PD) of the bull's non-return rate (NRR) from the average NRR of all bulls in the Select Sires Inc. reproductive management program. Group 1 (high fertility bulls, $\mathrm{n}=8$ ) $1.9 \leq \mathrm{PD} \leq 2.7 \%$ and group 2 (low fertility bulls, $\mathrm{n}=8)-6.5 \leq \mathrm{PD} \leq 1.8 \%$.

\section{Seminal plasma ELISA}

Frozen semen samples from $0.5 \mathrm{ml}$ insemination straws were thawed at room temperature and centrifuged in three 15 -minute cycles at $4^{0} \mathrm{C}$ to obtain seminal plasma. Relative centrifugal force $(\mathrm{RCF})$ equaled 400,800 , and $1200 \times \mathrm{g}$ per cycle, respectively. Concentrations of TGF- $\beta 1$ in seminal plasma samples were analyzed by the DuoSet ${ }^{\circledR}$ 
ELISA protocol (R \& D Systems, Minneapolis, MN). Seminal plasma samples were assayed with $2.5 \mathrm{~N}$ acetic acid/ $10 \mathrm{M}$ urea activation to determine total TGF $\beta-1$ (active plus latent contents). A $3 \times$ dilution factor, $\mathrm{CV}<20 \%, 12$-point standard curve and $\mathrm{R}^{2}$ (0.99) were used.

\section{Electrophoresis}

Frozen samples of seminal plasma were thawed at room temperature and centrifuged at $10,000 \times g$ for $60 \mathrm{~min}$ at $4^{0} \mathrm{C}$. The supernatant was processed by 2 -D Clean-UP protocol (GE Healthcare, Piscataway, NJ) to remove impurities such as nucleic acids, lipids and salts. Samples were then assayed for protein content (Lowry et al., 1951) using BSA as standards, and aliquots frozen at $-80^{\circ} \mathrm{C}$. Samples for electrophoresis were thawed at room temperature, concentrated to $1-10 \mathrm{mg} / \mathrm{ml}$ and labeled with cyanine dye (CyDye) DIGE Fluor $\mathrm{Cy} 3 / 5$ at a ratio of $50 \mu \mathrm{g}$ protein to $400 \mathrm{pmol}$ fluor and counterbalanced across the sample groups. A pooled internal standard was created from equal aliquots of each sample and labeled with Cy2 dye. Samples were separated by isoelectric focusing on an Ettan $^{\mathrm{TM}}$ IPGphor ${ }^{\mathrm{TM}}$ apparatus using $24 \mathrm{~cm}$ Immobiline DryStrip gels (GE Healthcare, Piscataway, NJ) containing a mixture of ampholytes with $\mathrm{pH}$ from 3 to 10 .

Following isoelectric focusing, strip gels were transferred to $24 \mathrm{~cm}$ Tris-Tricine gradient gels mounted on low-fluorescence glass plates and proteins separated by molecular mass in the second dimension using Ettan ${ }^{\mathrm{TM}}$ Dalt II Electrophoresis System (GE Healthcare, Piscataway, NJ). Dalt gels were scanned using a Typhoon 9400 Variable Mode imaging densitometer (GE Healthcare, Piscataway, NJ) at $100 \mu \mathrm{m}$ resolution. A 
fully automated image analysis software, Progenesis SameSpots ${ }^{\mathrm{TM}}$ (Nonlinear Dynamics, Durham, NC), was used to analyze the protein expression data.

\section{Statistical analysis}

Data on concentration of TGF- $\beta 1$ were examined by analysis of variance using PROC GLM procedures of SAS (SAS Institute, Cary, NC). The model statement included the fixed effects of fertility group, collection and random effect of bull. Post hoc analyses (t-test and Tukey's LSD) were used to evaluate significant differences in samples means at probability $\leq 0.05$.

The internal standard was essential for assessing biological and experimental (between gels) variations and increasing the robustness of statistical analysis. Individual protein data from sample groups (Cy3 or Cy5) were normalized against the Cy2 labeled sample. Scanned images of the labeled proteins were sequentially analyzed by differential in-gel analysis (DIA) that performed $\mathrm{Cy} 3 / \mathrm{Cy} 5: \mathrm{Cy} 2$ normalization, and then by biological variation analysis (BVA) that performed inter-gel statistical analysis to provide relative abundance in various groups. Log abundance ratios were then compared between sample groups using ANOVA and t-test in Progenesis SameSpots. The analyzed spots were ranked by their probability values and then grouped into high and low CF for further evaluation. Principal component analysis (PCA) was used to determine the presence of outliers in that data and also to compare how well the samples fitted to the experimental groups. The expression profiles of the selected proteins were then examined by correlation analysis. 


\section{Protein identification}

A list of protein spots of interest (pick-list) was generated by the image analysis software and exported directly into a Spot Picking Ettan ${ }^{\mathrm{TM}}$ Spot Handling Workstation (GE Healthcare, Piscataway, NJ) equipped to automatically pick spots from the Dalt gels. Selected protein spots were washed by $50 \mathrm{mM}$ ammonium bicarbonate $/ 50 \%$ (vol/vol) methanol in water, dried by vacuum centrifugation, and incubated overnight at $37^{\circ} \mathrm{C}$ in $140 \mathrm{ng}$ of sequencing grade trypsin (Koc et al., 2001). Tryptic digests were analyzed by capillary liquid chromatography-nanoelectrospray ionization-tandem mass spectrometry (CapLC-MS/MS). Proteins were identified by MS/MS ion searches performed on the processed spectra against the SwissProt and NCBI protein databases using a Bioworks Browser 3.1 (Thermo Finnigan, San Jose, CA) search engine. The identification of protein was confirmed when the Bioworks confidence interval was greater than $95 \%$ (Figure 10). The protein mass and $p I$ accuracy on the $2 \mathrm{D}$ gel was used as a guide to confirm protein identification (Table 10).

\section{Results}

Seminal plasma TGF- $\beta 1$

Concentrations of TGF- $\beta 1$ in seminal plasma differed $(P=0.001)$ among bulls but were not affected by time of collection $(P=0.3)$ or by the interaction of fertility group and time of collection ( $P=0.48$, Figure 4$)$. Concentrations of TGF- $\beta 1$ in seminal plasma did not differ $(P=0.35)$ between bulls with high and low fertility scores $(61.7 \pm$ 15.1 vs. $39.3 \pm 16.2 \mathrm{pg} / \mathrm{ml}$, Figure 5) because of high variability among bulls.

\section{Seminal plasma proteome}




\section{Distribution of protein spots in seminal plasma of dairy bulls}

Three patterns of protein expression were consistently observed in seminal plasma samples of cryopreserved semen (Figure 6). Spot volume analysis and peptide identification indicated a higher expression of proteins from semen extender at the molecular weight range between 30 to $60 \mathrm{kDa}$ accounting for $55 \%$ of protein spots by Coomassie staining. A "train" of spots was visible within the 20 to $25 \mathrm{kDa}$ range accounting for about $35 \%$ of the spot volume while the remaining spots $(10 \%)$ were expressed below the $20 \mathrm{kDa}$ range (Figure 7). Surprisingly, there was a two-fold difference in total protein content between extended and non-extended seminal plasma ( $41.6 \pm 2.3$ vs. $19.5 \pm 2.1 \mathrm{ng} / \mathrm{mL}$, respectively).

\section{Expression patterns between treatment groups}

There was no difference $(\mathrm{P}>0.05)$ in the expression pattern of proteins in cryopreserved seminal plasma of high vs. low fertility bulls, therefore, subsequent analyses were done between cryopreserved (processed) and non-cryopreserved (unprocessed) seminal plasma of low fertility bulls. A total of 54 spots differed (P < 0.001) in their expression pattern between processed vs. unprocessed seminal plasma. The spots were then examined by principal component analysis and clustered into two groups: those that were highly expressed in processed seminal plasma but not in unprocessed seminal plasma and vice versa (Figure 8). Approximately 31 spots (57.4\%) were highly expressed in seminal plasma of unprocessed semen. The remaining 23 spots $(42.6 \%)$ were highly expressed in seminal plasma of processed semen.

\section{Protein identification}


A reference image was generated from the expression data and used to pick spots for protein identification (Figure 9). Extender derived proteins, mainly chicken vitellogenin-2 (MW $20.5 \mathrm{kDa}$ ), fibrinogen $\beta$ chain (MW 52.70) and chicken albumin, were predominantly identified from spots above $20 \mathrm{kDa}$ in seminal plasma of processed semen. These proteins masked identification of any bovine seminal plasma proteins within this range. Below $20 \mathrm{kDa}$ range, greater amounts of spermadhesin (SPAD1 and Z13) isoforms were expressed than the major bovine seminal plasma proteins (PDC-109 and BSP-A3).

In the absence of extender proteins in unprocessed seminal plasma, several spots above $20 \mathrm{kDa}$ were positively identified (Table 10). Notable among these proteins were nucleobindin-1, clusterin, phospholipase $\mathrm{A}_{2}$ isoforms, seminal plasma protein $\mathrm{BSP}-30$ $\mathrm{kDa}$, metalloproteinase inhibitor-2 and cathepsins (B and D). Below the $20 \mathrm{kDa}$ range in unprocessed seminal plasma, major seminal plasma proteins (PDC-109 and BSP-A3) predominated over the spermadhesins (Figure 9).

\section{Discussion}

Analysis of seminal plasma TGF- $\beta 1$ content

Transforming growth factor- $\beta$ is a cytokine with an unusually broad range of functions. Cell proliferation, regulation of apoptosis and matrix formation are some of the key effects of the cytokine on cells. Systemic effects include regulation of immune system, development, tissue homeostasis and repair. Another unusual component of TGF- $\beta$ biology is the fact that it is secreted in a latent form and that activation of the latent form is required before signaling can occur (Munger et al., 1997). Secreted TGF- $\beta$ is noncovalently associated with latency associated peptide (LAP) which in turn has a 
disulfide link with latent TGF- $\beta$ binding protein (LTBP). Signaling agents in seminal plasma influence the physiology of the reproductive tract of females and improve conception and pregnancy rates in rodents, human beings and pigs (Pang et al., 1979; Murray et al., 1983; Robertson et al., 2002). Immediately after mating, seminal plasma triggers an acute inflammatory response - involving recruitment of antigen presenting cells and controlled cytokine (e.g. GM-CSF, chemokines) production. The response is proposed to initiate the tolerance response to paternal antigens (Robertson et al., 1997; Johansson et al., 2004). Transforming growth factor- $\beta 1$ is a major constituent of seminal plasma in rodents and human beings and appears to be a major contributor to these actions (Tremellen et al., 1998; Robertson et al., 2002).

The aim of the present study was to investigate whether total concentrations of TGF- $\beta 1$ (latent + free form) in seminal plasma of dairy bulls might be used as potential indicators of their fertility. The results implied that there was no indication of relationship between concentrations of TGF- $\beta 1$ in seminal plasma of bulls and their fertility phenotypes. In addition, the amount of TGF- $\beta 1$ in seminal plasma was not influenced by the interaction of time of semen collection and fertility phenotype. However, due to high variability in the amount of TGF- $\beta 1$ among bulls within fertility phenotype and among collections within bull, it is not possible to determine whether the results were true biological observations or experimental errors. Bioactive TGF- $\beta$ peptides are rapidly inactivated in living cells and consequently not usually detectable in tissues, body fluids, or supernatants from cultured cells (Tesseur et al., 2006). However, latent TGF- $\beta$ in such samples can be activated with acids, heat, or other methods (Mazzieri et al., 2000). Greater concentrations of TGF- $\beta 1$ have been reported in serum and cerebrospinal fluid of 
patients with neurodegenerative diseases (Ilzecka et al., 2002). However, little or no data has been reported on concentrations of TGF- $\beta 1$ in seminal plasma of domestic animals. Holaskova (2007) sampled blood and semen from rams and beef bulls to determine the relationships of their TGF- $\beta 1$ content to sperm characteristics (\% motility and normal morphology). No relationships were observed between concentrations of TGF- $\beta 1$ in serum and seminal plasma nor were there any relationships between seminal plasma TGF- $\beta 1$ content and sperm characteristics. Men with spinal cord injuries exhibited inflammation-related infertility, but concentration of TGF- $\beta 1$ was found to be lower in their seminal plasma (Basu et al., 2004). Concentrations of TGF- $\beta 1$ (latent or free form) in seminal plasma were not different between normal and infertile human subjects. Furthermore, no differences were observed between subjects with high or normal plasma FSH concentrations, implying that most seminal plasma TGF- $\beta 1$ is not of testicular origin (Loras et al., 1999).

\section{Analysis of seminal plasma proteome}

An altered pattern of protein expression in seminal plasma of cryopreserved and non-cryopreserved dairy bull semen was demonstrated by this study. Consistent with previous reports, fertility associated proteins were identified in seminal plasma of low fertility bulls. These observations imply that semen processing might impact fertility of sperm from bulls that could have been of normal fertility phenotype.

During cryopreservation, major seminal plasma proteins are diluted out and replaced with extender proteins. However, the effect of cryopreservation on seminal plasma protein expression patterns has not been examined. Most artificial inseminations in cattle involve use of processed semen, and as a consequence, most fertility data have 
been derived from inseminations with processed semen. Therefore, it was prudent to utilize cryopreserved semen in this study to examine changes in its protein profile between low and high fertile bulls, and to compare processed and unprocessed semen.

Abundant low molecular weight bovine seminal plasma proteins were diluted out during cryopreservation and replaced by high molecular weight extender-derived chicken structural proteins. Major bovine seminal plasma proteins PDC-109 (BSP-A1/A2), BSPA3 and BSP-30 kDa play important roles in fertility by maintaining sperm in an appropriate state in the female tract until the oocyte reaches the site of fertilization (Thérien et al., 1997, 1998; Yu et al., 2003; Gwathmey et al., 2006). It is unclear whether the effect of processing that decreased the abundance of these BSP proteins by more than half would render them ineffective in preventing premature capacitation and acrosome reaction of sperm from normal fertility bulls in the female tract. Spot volume data indicated that removal of the major seminal plasma proteins exposed less abundant low molecular weight proteins like spermadhesins, especially spermadhesin Z 13 which has been identified as an antifertility factor (Killian et al., 1993; Moura et al., 2006) in bovine seminal plasma. Whether this altered protein profile after processing might impact fertility of semen from otherwise fertile bulls remains to be explored.

Killian et al. (1993) suggested that four bovine seminal plasma proteins were associated with fertility. These proteins were later characterized as Osteopontin and BSP$30 \mathrm{kDa}$ in high fertility bulls and Spermadhesin Z 13 in low fertility bulls (Moura et al., 2006). In the present study, seminal plasma protein expression did not differ between high and low fertility dairy bulls. A difference in protein expression between fertility groups had been demonstrated in a previous study (Moura et al., 2006). It was anticipated 
that by utilizing the multiplexing ability of the 2-DIGE technology, experimental errors would be minimized, and a more robust analysis would be achieved as opposed to the densitometric analysis utilized in the former study. The discrepancy in outcome between the two studies can be attributed to sample type utilized or fertility grouping, or both. Samples in the present study were from insemination straws as opposed to direct seminal plasma samples utilized in the previous study. Therefore, differential expression of proteins in samples examined in this study might have been affected by semen processing. Inadequate sample availability also impeded the classification of semen samples into distinct high and low fertile groups as was done in the previous study (Moura et al., 2006). Bulls used in the present study had percentage point deviations (PDs) from the average of $+2.7 \%$ to $-6.5 \%$. In contrast, the previous study had PDs from $+7.7 \%$ to $-18.1 \%$. Consequently, low and high fertility groups in the present study corresponded to the intermediate fertility groups in that study. Because the previous authors reported no differences in expression levels of Osteopontin, Spermadhesin Z13, Phospholipase $\mathrm{A}_{2}$ and BSP $30 \mathrm{kDa}$ among these two groups, it was not surprising that the groups did not differ in their seminal plasma protein profile in the present study.

Seminal plasma proteins have been characterized by other investigators and their association with male fertility continues to be explored (Mortarino et al., 1998; Gwathmey et al., 2003; Jobim et al., 2004; Moura et al., 2006; 2007). Functions of sperm that may be affected by seminal plasma proteins include capacitation, acrosome reaction, motility, DNA integrity and interaction with the oocyte (Moura et al, 2007).

Major BSP proteins (BSP-A1/A2, A3 and BSP-30 kDa) are known to influence capacitation by their ability to modulate membrane cholesterol. Phospholipase $\mathrm{A}_{2}\left(\mathrm{PLA}_{2}\right)$ 
and osteopontin are involved in acrosome reaction and sperm-oocyte interaction and possibly early embryonic development (Morura et al., 2007). Proteins that might be associated with interaction and modulation of extracellular matrix (ECM) components are TIMP-2, clusterin and cathepsins. These functions may be important during fertilization when the sperm is required to interact with and cross barriers established by the cumulus cells, zona pellucida and oocyte membrane. Albumin, aSFP and clusterin are involved either directly or indirectly in mechanisms aimed at preventing damage to sperm membrane, oxidative stress and immune attack. Proteins associated with sperm motility in the female reproductive tract include BSP A1/A2, aSFP, PLA2 and ecto 5'nucleotidase (5'-NT). Spermadhesin Z13 might also be included in the motility associated group because it shares 50\% homology with aSFP. However, expression of spermadhesin Z13 in seminal plasma of dairy bulls was inversely related to fertility (Moura et al., 2006).

\section{Conclusion}

Fertility studies in non-bovine animals provided evidence that low abundance proteins might provide useful markers of male fertility. Some of these proteins might not be detected by traditional 2-D electrophoresis. These studies will lead to more complete view of seminal plasma proteins and enhance our understanding of their role in animal fertility. 


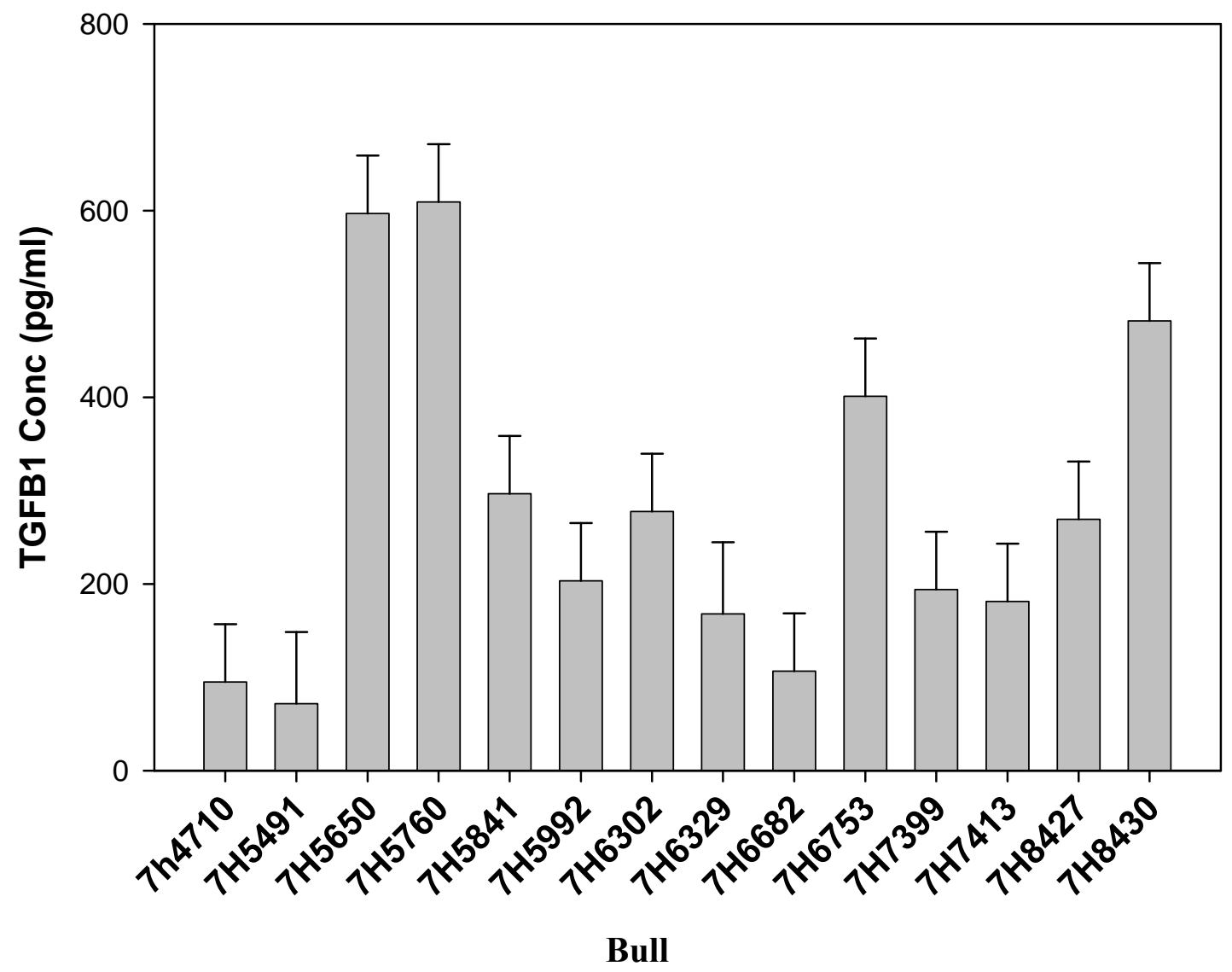

Figure 4: Concentrations of TGF- $\beta 1$ in seminal plasma of dairy bulls.

Effect tests:

* $\quad \operatorname{Bull}(P=0.001)$

* Collection $(P=0.30)$

* Collection $\times$ fertility index $(P=0.48)$ 


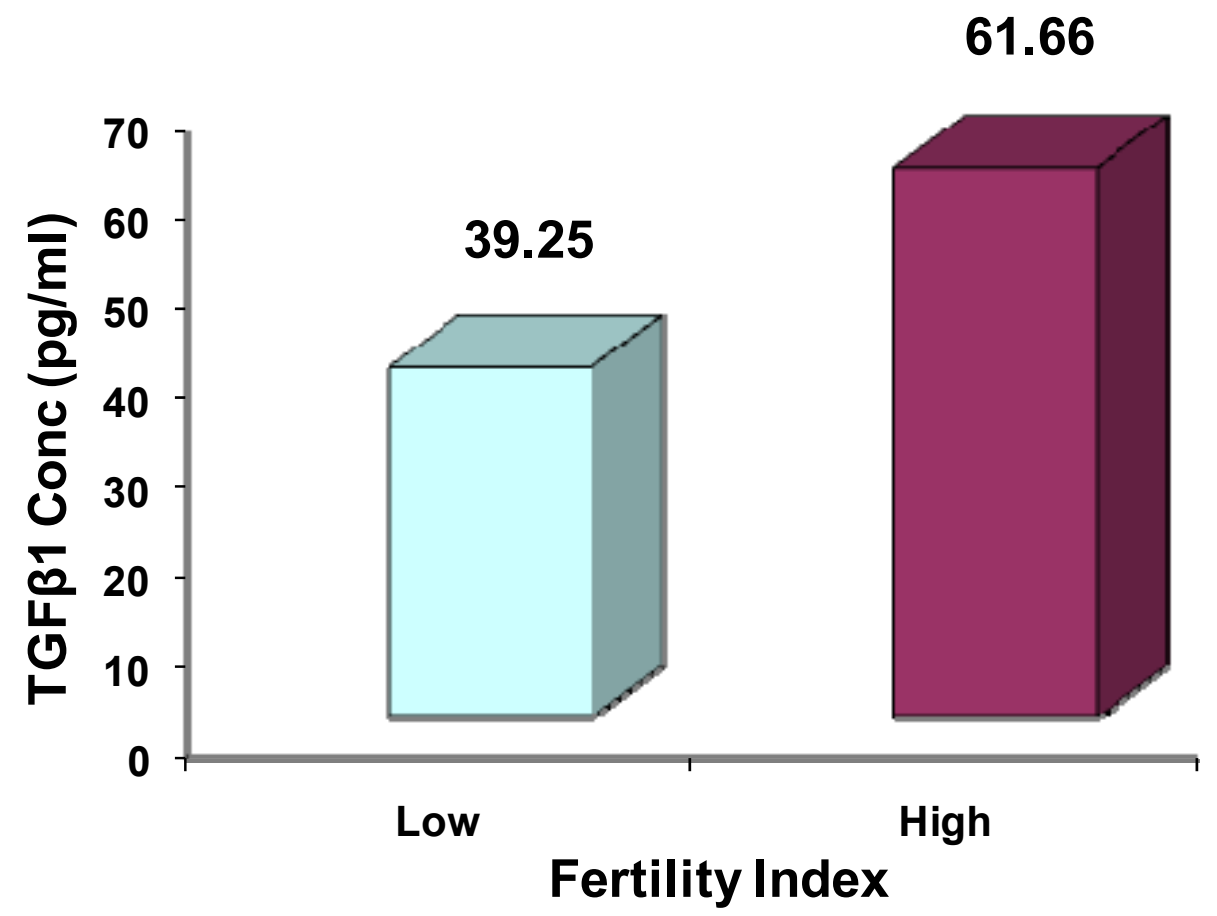

Figure 5: Concentrations of TGF- $\beta 1$ in seminal plasma of dairy bull of known fertility phenotypes $(P=0.35)$.

*Fertility score was expressed as the percentage point deviation (PD) of the bull's non-return rate (NRR) from the average NRR of all bulls in the Select Sires Inc. reproductive management program. High fertility bulls $(\mathrm{n}=8) 1.9 \leq \mathrm{PD} \leq 2.7 \%$, and low fertility bulls $(\mathrm{n}=6)-6.5 \leq \mathrm{PD} \leq$ $1.8 \%$. 


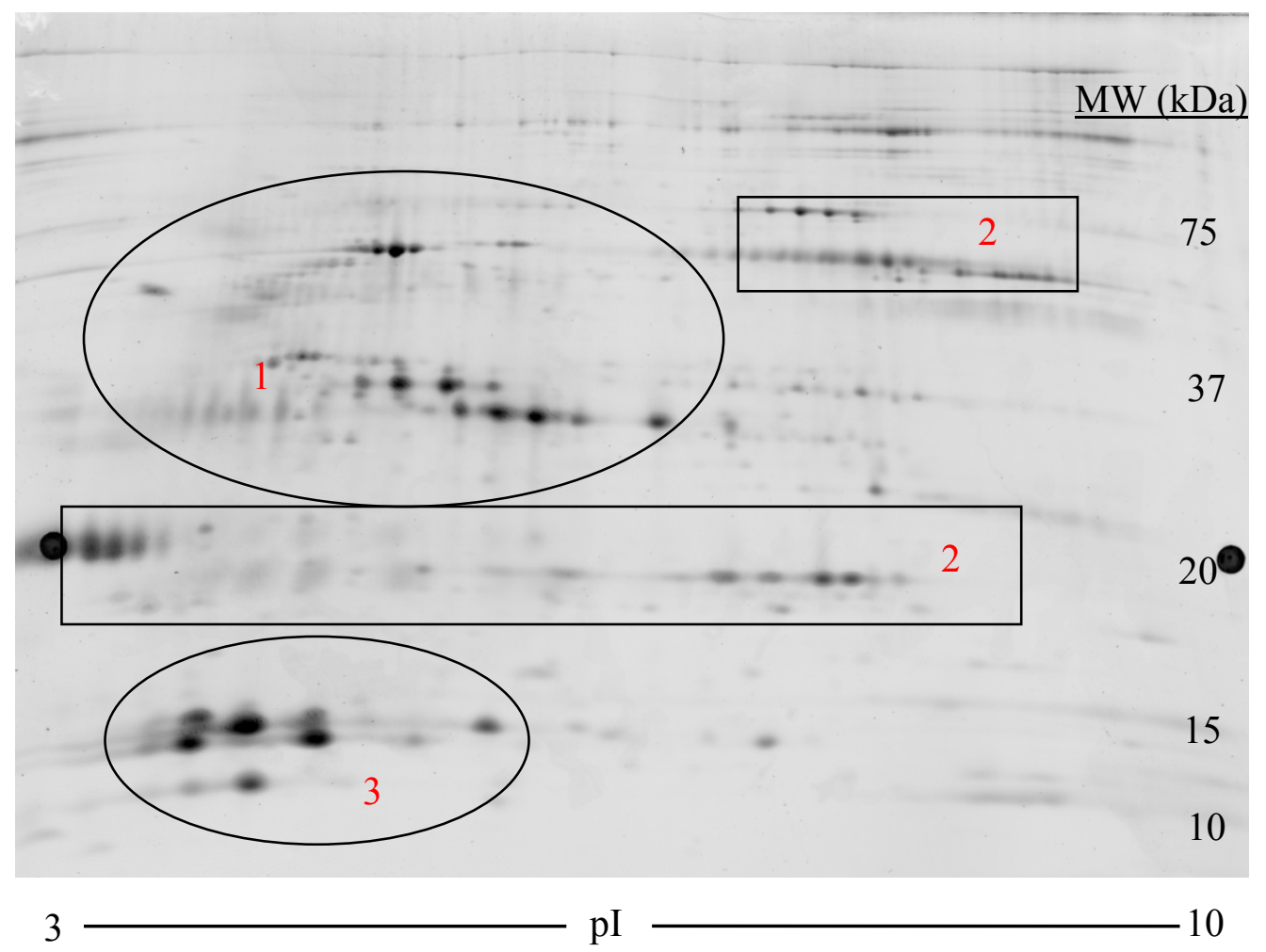

Figure 6: Reference gel depicting distribution of protein spots in seminal plasma of dairy bulls.

Protein spots were characterized as: 1) probable extender-derived proteins, 2) probable medium and high molecular weight seminal plasma proteins, and 3) major bovine seminal plasma proteins. 


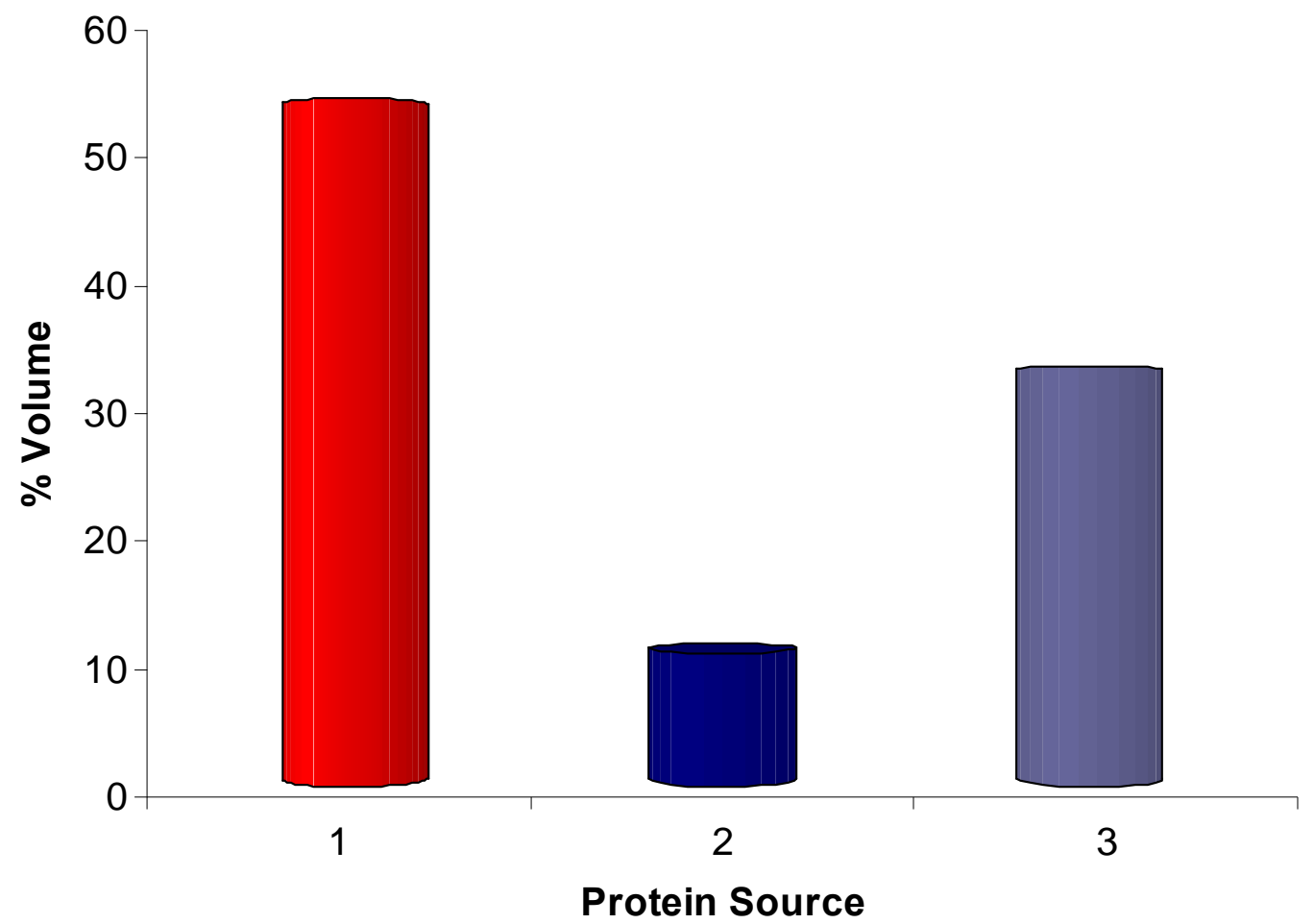

Figure 7: Analysis of distribution of protein spots by volume in seminal plasma of cryopreserved dairy bull semen.

Proteins spot were characterized as: 1) probable extender-derived proteins, 2) probable medium and high molecular weight seminal plasma proteins, and 3) major bovine seminal plasma proteins. 

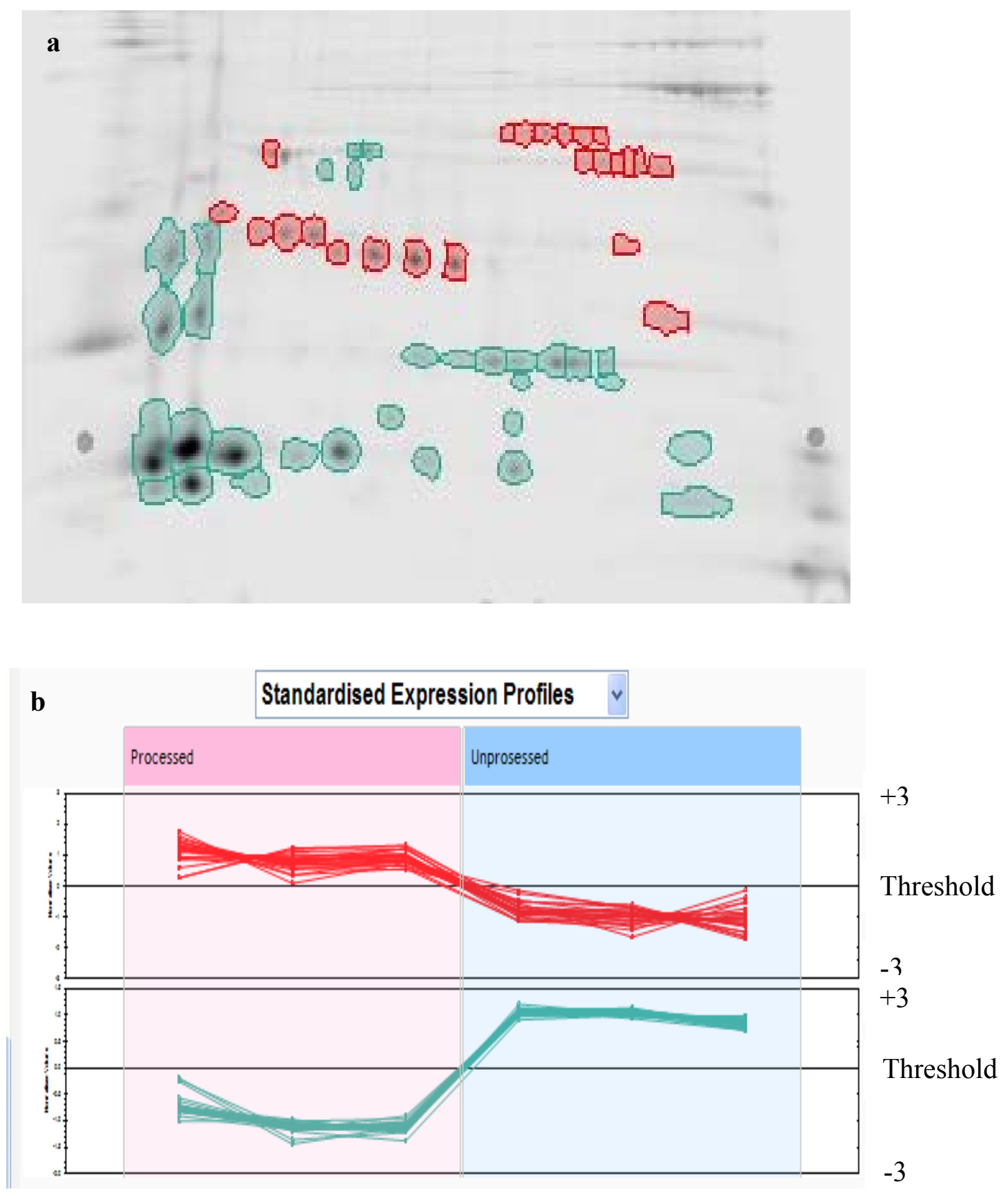

Figure 8: Cluster analysis of protein expression in seminal plasma of dairy bulls.

Reference gel (a) depicting protein spots that differed $(P<0.001)$ and their standard expression profiles (b) in processed (Red outlines) and unprocessed (Green outlines) semen. 


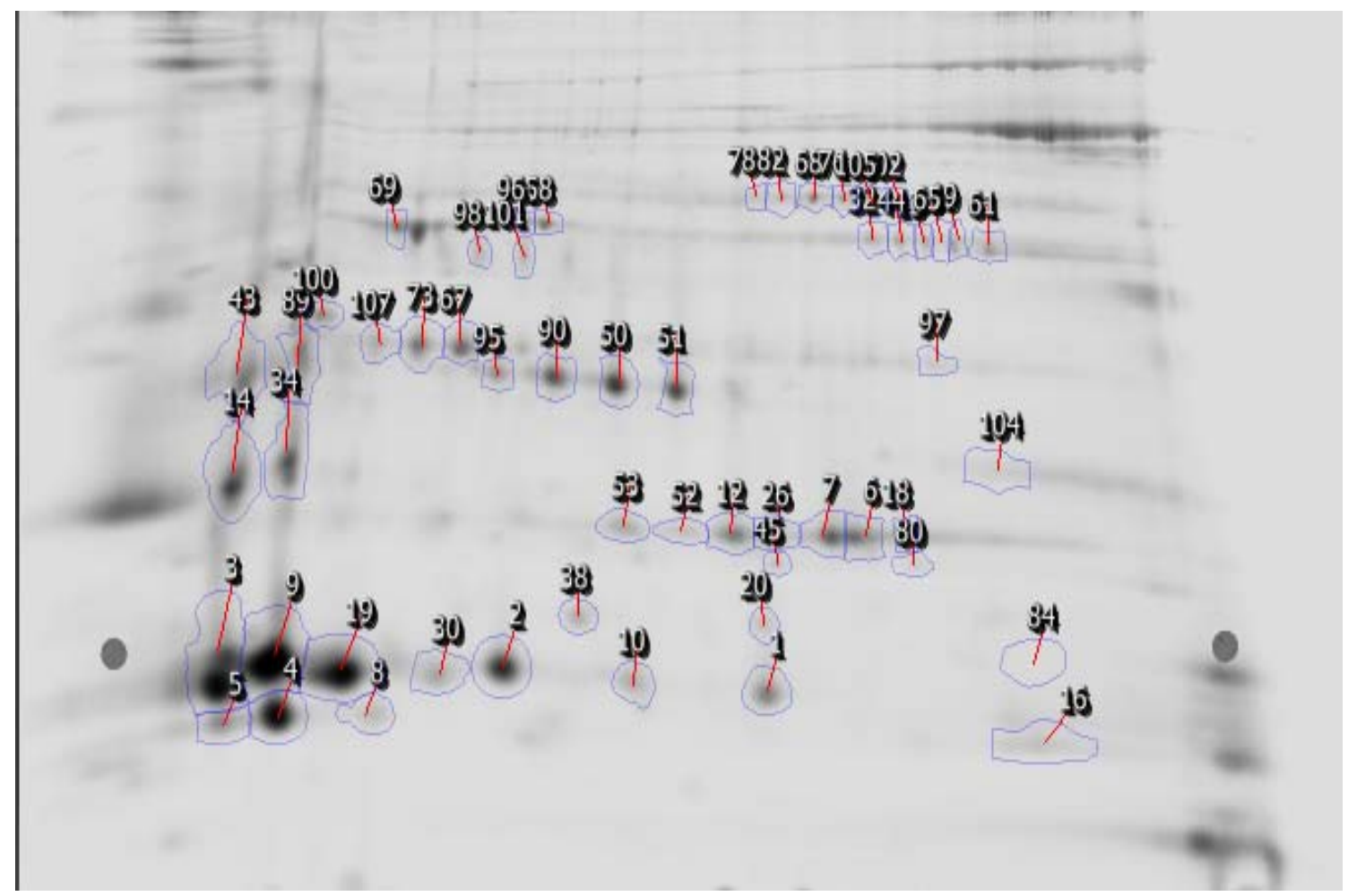

Figure 9: Pick list for protein spots that differed between seminal plasma from processed and unprocessed dairy bull semen. Thirty spots from this list were picked and digested for protein identification by MALDI-TOF and LC-MS/MS mass spectrometry. 


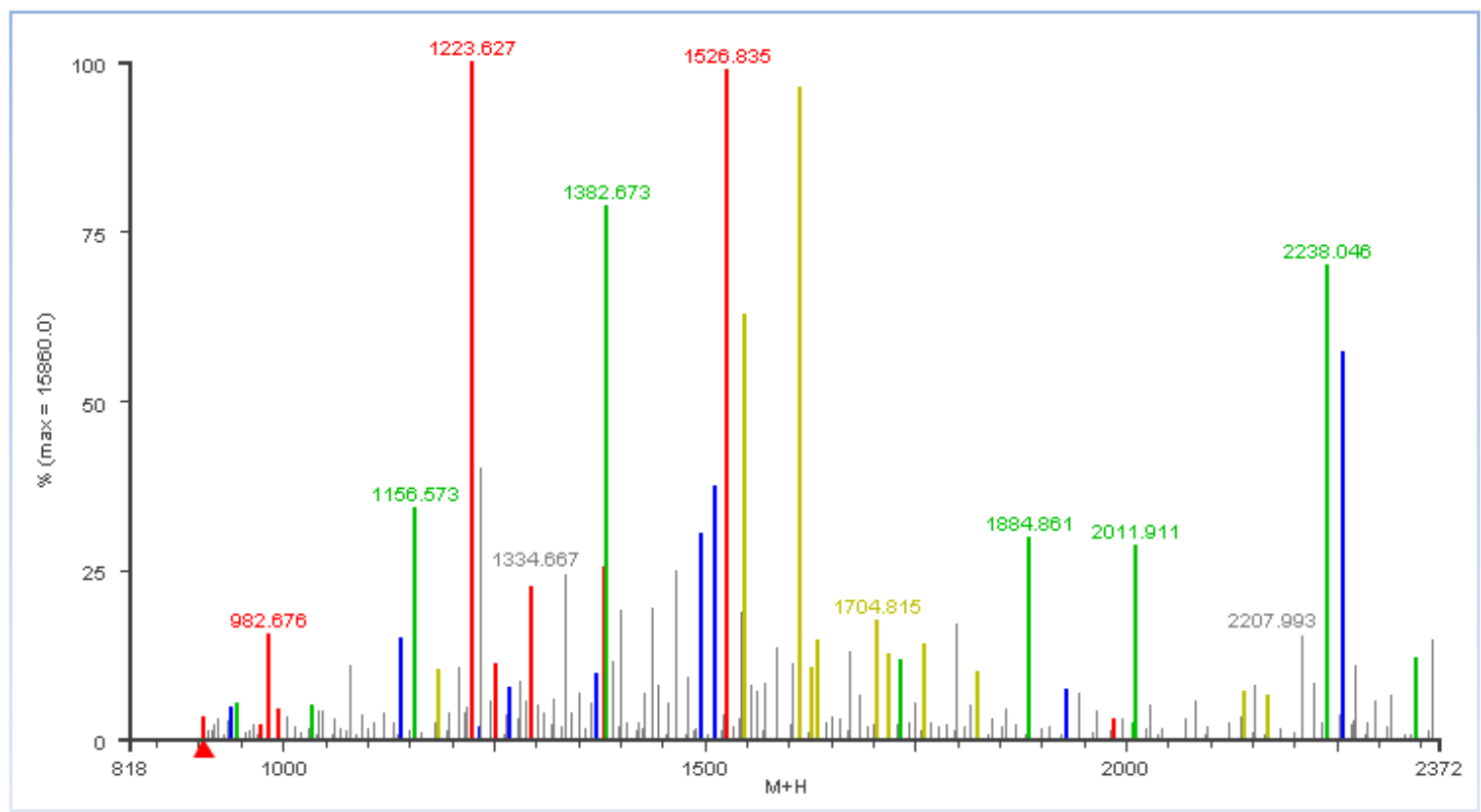

Figure 10: Mass ion spectrum of a positively identified protein by MALDI-TOF mass spectrometer. Colored bars indicate complemetary peptide matches with the protein sequence in database. Grey bars indicate no matching with data base sequences. 


\begin{tabular}{|c|c|c|c|c|c|c|}
\hline Gel ID & $\begin{array}{c}\text { Fold } \\
\text { Increase }^{*}\end{array}$ & Protein ID & $\begin{array}{c}\text { Accession } \\
\text { number }\end{array}$ & $\begin{array}{c}\text { Coverage } \\
\%\end{array}$ & $\begin{array}{c}\text { Molecular } \\
\text { weight }\end{array}$ & pI \\
\hline \multicolumn{7}{|c|}{ Membrane stabilizing proteins } \\
\hline 1 & 95.4 & Spermadhesin Z13 & P82292 & 44 & 15.2 & 6.3 \\
\hline 19 & 30.2 & Spermadhesin Z13 & P82292 & 43.3 & 15.2 & 6.3 \\
\hline 3 & 54.4 & Spermadhesin 1 & P29392 & 78.4 & 15 & 5.1 \\
\hline 20 & 30.1 & $\begin{array}{l}\text { Epididymal } \\
\text { secretory protein } \\
\text { E1 }\end{array}$ & P79345 & 55 & 16.6 & 8.4 \\
\hline \multicolumn{7}{|c|}{ ECM interacting proteins } \\
\hline 6 & 38.8 & Cathepsin B & Р07688 & 16.1 & 36.7 & \\
\hline 26 & 27.3 & CathepsinD & P80209 & 5.1 & 42.5 & \\
\hline 43 & 20.4 & Clusterin & P17697 & 31.4 & 51.1 & 6 \\
\hline 12 & 33.9 & $\begin{array}{l}\text { Metalloproteinase } \\
\text { inhibitor } 2\end{array}$ & P16368 & 42.7 & 24.3 & 7.8 \\
\hline \multicolumn{7}{|c|}{ Capacitation/acrosome reaction proteins } \\
\hline 9 & 37.3 & BSP-A1/A2 & P02784 & 44.8 & 15.5 & 4.9 \\
\hline 19 & 30.2 & $\mathrm{BSP} \mathrm{A} 1 / \mathrm{A} 2 \dagger$ & P02784 & 44.8 & 15.5 & 4.9 \\
\hline 34 & 24.6 & BSP-30kDa & P81019 & 27.9 & 21.3 & 5.9 \\
\hline 51 & 17.1 & Phospholipase A2 & IPI00760435.1 & 47.1 & 50.1 & 6.5 \\
\hline 90 & 7.9 & $\begin{array}{l}\text { Platelet-activating } \\
\text { factor } \\
\text { acetylhydrolase }\end{array}$ & Q28017 & 53.2 & 50.1 & 6.5 \\
\hline 100 & 5.5 & Nucleobindin-1 & Q0P569 & 63.1 & 54.9 & 5.2 \\
\hline \multicolumn{7}{|c|}{ Ubiquitination proteins } \\
\hline 14 & 33.3 & Kelch-like protein 9 & Q2T9Z7 & 24.5 & 153.6 & 8.8 \\
\hline \multicolumn{7}{|c|}{ Motility associated proteins } \\
\hline 30 & 26.4 & $\begin{array}{l}\text { Fast myosin heavy } \\
\text { chain extraocular }\end{array}$ & IPI00829549.2 & 30.6 & 186.1 & 5.7 \\
\hline
\end{tabular}

Table 10: Proteins identified from corresponding spots in figure 9.

*Spot volumes differed in relative amounts compared to internal standard.

$\dagger$ Protein was identified at this spot only in unprocessed semen.

\$dentification at this spot was enhanced by semen processing. 


\section{General discussion}

Reproductive efficiency is the hallmark of any profitable cattle operation because of the reliance on annual calf crop in the beef industry and the requirement of parturition to renew lactation in dairy cows. Therefore, the goal of any reproductive management is to ensure that cows breed at an opportune time and maintain their pregnancy to term.

Over forty years ago, failure to conceive or early embryonic death accounted for the largest losses in calf crop in beef production (Wiltbank et al., 1961). Thirty years later, failure to conceive during the end of the breeding season was reported to account for the greatest production loss in the cow-calf segment of the beef industry (Bellows and Short, 1994). Today (Geary, 2003), the most common reproductive problem facing the beef industry is getting first-calf heifers rebred. In the dairy industry, poor oocyte quality (Ahmad et al., 1995; Perry et al., 2007) and failure of attachment (Starbuck et al., 2004; Rhinehart et al., 2008) account for the largest pregnancy losses. In a recent review of embryonic death in cattle, Inskeep and Dailey (2005) reported that about $10 \%$ of pregnancy failures in cows occur due to factors associated with the male. However, little attention has been paid to contributions in pregnancy failures due to male factors.

The series of studies reported here were designed with the aim of improving reproductive management in beef and dairy cattle. In experiment one, lactational stress in the pregnant younger cows was considered an impediment to postpartum reproductive efficiency in beef cattle. Therefore, the effect of an intervention by an early weaning regimen on body energy metabolic profile and reproductive performance was examined in a beef herd. Cow response to weaning treatment was determined to a greater extent by her age/parity. Consequently, the importance of age profiles in a herd cannot be 
overemphasized when designing management strategies for improving reproductive efficiency in cattle. The utility of ultrasonic scans of rump fat was identified as a viable alternative to body condition scores in evaluating or managing nutritional status of cows during the production cycle.

In experiment two, the impact of stimuli expected to cause a post-mating inflammatory response on pregnancy outcome was examined in beef and dairy cows. Because previous studies in rodents, humans and pigs have indicated the need for seminal plasma proteins for successful pregnancies to occur in these species, a study was designed to extend this developing hypothesis in cattle. Inseminations with adjunctive seminal plasma numerically improved conception rates consistently in dairy and beef cattle, irrespective of whether they were timed bred or bred after synchronized estrus, and whether the treatments were applied at breeding or 12 hours before breeding. Inseminations with adjunctive TGF- $\beta 1$ were only effective in cases where fertility were compromised, for example in dairy cows. These observations when combined with previous strategies that incorporated treatments with recombinant bovine somatotropin (Starbuck et al., 2006) at insemination in cows greater than 100 days in milk, or transfer of in vitro produced embryos to heat-stressed lactating cows (Block and Hansen, 2007) might provide practical applications in managing reproductive efficiency in dairy cows.

In experiment three, examination of the role of male factors in ensuring reproductive competence was extended to investigate the existence of potential biomarkers of fertility in seminal plasma. Divergent views exist on whether these biomarkers are located on the sperm surface (Sutovsky, 2003; Peddinti et al., 2008), or are associated with sperm DNA (Wu and Chu, 2008) or in seminal plasma (Cancel et al, 
1997; Moura et al., 2006; 2007). Comparisons were carried out in seminal plasma from processed or unprocessed semen to evaluate the effect of semen processing on expression patterns of established biomarkers in seminal plasma. Altered expression profiles of the fertility-associated bovine seminal plasma proteins were observed in processed semen. A reduction in total protein content of seminal plasma from the processed semen also was observed. Taken together, these observations might imply that semen processing might impact fertility of sperm from bulls that could have otherwise been considered fertile. However, the mechanism by which these seminal plasma proteins might impact pregnancy outcome remains unexplored.

\section{Conclusions}

Reproductive efficiency in primiparous beef cattle can be improved by modulating the effects on lactational stress during mid to late pregnancy. Early weaning improved reproductive performance in 2- and 3-yr-old beef cows than in the older age groups. Ultrasonic rump fat scan offered a better alternative measure of nutritional status of cows compared to BCS or body weight. Inseminations with adjunctive seminal plasma proteins or their incorporation into semen during processing might improve reproductive performance in dairy cows. Alteration of seminal plasma proteome during semen processing might compromise fertility of sperm from bulls that could have otherwise been considered fertile. These observations add to several other alternative options that producers have in choosing the right strategy to fit to their reproductive management programs. 


\section{Literature cited}

1. Acosta, B., G. K. Tarnavsky, T.E. Platt, D.L. Hamernik, J. L. Brown and H. M. Schoenemann, and J. J. Reeves. 1983. Nursing enhances the negative effect of estrogen on LH release in the cow. J. Anim. Sci. 57:1530-1536.

2. Ahmad, N., F. N. Schrick, R. L. Butcher, and E. K. Inskeep. 1995. Effect of persistent follicles on early embryonic losses in beef cows. Biol Reprod 52: 11291135.

3. Alberio, R. H., G. Schiersmann, N. Carou, and J. Mestre. 1987. Effect of a teaser bull on ovarian and behavioural activity of suckling beef cows. Ani. Reprod. Sci. 14: $263-272$.

4. Alghamdi, A. S., D. N. Foster, and M. H. T. Troedsson. 2004. Equine seminal plasma reduces sperm binding to polymorphonuclear neutrophils (PMNs) and improves the fertility of fresh semen inseminated into inflamed uteri. Reproduction 127: 593-600.

5. Arije, G. R., J. N. Wiltbank, and M. L. Hopwood. 1974. Hormone levels in preand post-parturient beef cows. J. Anim. Sci. 39: 338-347.

6. Arthington, J.D., and R. S. Kalmbacher. 2003. Effect of early weaning on the performance of three-year-old, first-calf beef heifers and calves reared in the subtropics. J. Anim. Sci. 81: 1136-1141.

7. Baker, J. F., and M. E. Boyd. 2003. Evaluation of age of dam effects on maternal performance of multilactation daughters from high- and low-milk EPD sires at three locations in the southern United States. J. Anim. Sci. 81:1693-1699.

8. Banos, G., S. Brotherstone, and M. P. Coffey. 2004. Evaluation of body condition score measured throughout lactation as an indicator of fertility in dairy cattle. J. Dairy Sci. 87: 2669-2676.

9. Baska, K. M., G. Manandhar, D. Feng, Y. Agca, M. W. Tengowski, M. Sutovsky, Y. J. Yi, and P. Sutovsky. 2008. Mechanism of extracellular ubiquitination in the mammalian epididymis. J Cell Physiol. 215(3):684-96.

10. Basu, S., T. C. Aballa, S. M. Ferrell, C. M. Lynne, and N. L. Brackett. 2004. Inflammatory cytokine concentrations are elevated in seminal plasma of men with spinal cord injuries. J. Andrology 25:250-254.

11. Beam, S. W., and W. R. Butler. 1997. Energy balance and ovarian follicle development prior to the first ovulation postpartum in dairy cows receiving three levels of dietary fat. Biol. Reprod. 56: 133-142. 
12. Beam, S. W., and W. R. Butler. 1999. Effects of energy balance on follicular development and first ovulation in postpartum dairy cows. J. Reprod. Fertil. (Suppl.) 54: 411-424.

13. Bell, A. W. 1995. Regulation of organic nutrient metabolism during transition from late pregnancy to early lactation. J. Anim. Sci. 73: 2804-2819. Review.

14. Bell, D. J., J. C. Spitzer, and G. L. Burns. 1998. Comparative effects of early weaning or once-daily suckling on occurrence of postpartum estrus in primiparous beef cows. Theriogenology 50: 707-715.

15. Bellows, R. A., and R. E. Short. 1978. Effects of precalving feed level on birth weight, calving difficulty and subsequent fertility. J. Anim. Sci. 46: 1522-1528.

16. Bellows, R. A., and R. E. Short. 1994. Reproductive losses in the beef industry. In M. J. Fields and R. S. Sands (Eds) Factors Affecting Calf Crop. CRC Press, Baton Rouge, FL pp109-133.

17. Bellows, R. A., E. E. Grings, D. D. Simms, T. W. Geary, and J. W. Bergman. 2001. Effects of feeding supplemental fat during gestation to first-calf beef heifers. Prof. Anim. Sci. 17:81-89.

18. Berardinelli, J. G., and P. S. Joshi. 2005. Resumption of postpartum ovarian cycling activity in primiparous restricted suckled beef cows exposed to a bull or excretory products of bulls or cows. J. Anim. Sci. 83: 2495-2500.

19. Berardinelli, J. G., R. A. Dailey, R. L. Butcher, and E. K. Inskeep. 1979. Source of progesterone prior to puberty in beef heifers. J. Anim. Sci. 49: 1276-1280.

20. Berardinelli, J. G., R. L. Fogwell, and E. K. Inskeep. 1978. Effect of electrical stimulation or presence of a bull on puberty in beef heifers. Theriogenology 9:133.

21. Berardinelli. J. G., and S. A. Tauck. 2007. Intensity of the biostimulatory effect of bulls on resumption of ovulatory activity in primiparous, suckled, beef cows. Anim. Reprod. Sci. 99: 24-33.

22. Bischof, R. J., C. S. Lee, M. R. Brandon, and E. Meeusen. 1994. Inflammatory response in the pig uterus induced by seminal plasma. J Reprod Immunol 26:131146.

23. Blasi, D. A., R. J. Rasby, I. G. Rush and C. R. Quinn. N. D. Cow body condition scoring management tool for monitoring nutritional status of beef cows. $\mathrm{BCH}-$ 5405. Available: http://www.iowabeefcenter.org/pdfs/bch/05405.pdf. Accessed Nov 2008. 
24. Block, J., and P. J. Hansen. 2007. Interaction between season and culture with insulin-like growth factor-1 on survival of in vitro produced embryos following transfer to lactating dairy cows. Theriogenology 67:1518-29.

25. Brethour, J. R. 1992. The repeatability and accuracy of ultrasound in measuring backfat of cattle. J. Anim. Sci. 70: 1039-1044.

26. Breuel, K. F., P. E. Lewis, E. K. Inskeep, and R. L. Butcher. 1993a. Endocrine profiles and follicular development in early-weaned postpartum beef cows. J. Reprod. Fertil. 97: 205-212.

27. Breuel, K. F., P. E. Lewis, F. N. Schrick, A. W. Lishman, E. K. Inskeep, and R. L. Butcher. 1993b. Factors affecting fertility in the postpartum cow: Role of the oocyte and follicle in conception rate. Biol. Reprod. 48: 655-661.

28. Bridges, P. J., D. J. Wright, W. I. Buford, N. Ahmad, H. Hernandez-Fonseca, M. L. McCormick, F. N. Schrick, R. A. Dailey, P. E. Lewis, and E. K. Inskeep. 2000. Ability of induced corpora lutea to maintain pregnancy in beef cows. J. Anim. Sci. 78: 2942-2949.

29. Bridges, P. J., R. Taft, P. E. Lewis, W. R. Wagner, and E. K. Inskeep. 2000. Effect of the previously gravid uterine horn and postpartum interval on follicular diameter and conception rate in beef cows treated with estradiol benzoate and progesterone. J. Anim. Sci. 78:2172-2176.

30. Browning, R. Jr, B. S. Robert, A. W. Lewis, D. A. Neuendorff and R. D. Randel. 1994. Effects of postpartum nutrition and once-daily suckling on reproductive efficiency and preweaning calf performance in fall-calving Brahman (Bos indicus) cows. J. Anim. Sci.72: 984-989.

31. Burns, P. D., and J. C. Spitzer. 1992. Influence of biostimulation on reproduction in postpartum beef cows. J. Anim. Sci. 70: 358-362.

32. Buskirk, D. D., R. P. Lemenager, and L. A. Horstman. 1992. Estimation of net energyrequirements $\left(\mathrm{NE}_{\mathrm{m}}\right.$ and $\mathrm{NE} \Delta$ ) of lactating beef cows. J. Anim. Sci. 70 : $3867-3876$.

33. Butler, W. R. 2000. Nutritional interactions with reproductive performance in dairy cattle. Anim. Reprod. Sci. 60-61:449-457.

34. Caballero, I., J. M. Vazquez, M. A. Gil, J. J. Calvete, J. Roca, L. Sanz, I. Parrilla, E. M. Garcia, H. Rodriguez-Martinez, E. A. Martinez. 2004. Does seminal plasma PSP-I/PSP-II spermadhesin modulate the ability of boar spermatozoa to penetrate homologous oocytes in vitro? J Androl. 25(6):1004-12.

35. Cancel, A. M., D. A. Chapman, and G. J. Killian. 1997. Osteopontin is the 55kilodalton fertility-associated protein in Holstein bull seminal plasma. Biol Reprod. 57(6):1293-301. 
36. Casida, L. E. 1968. The postpartum cow-A resume. Univ. of Wisconsin Res. Bull. No. 270, pp 48-54, Madison.

37. Casida, L. E. 1971. The postpartum interval and its relation to fertility in the cow, sow and ewe. J. Anim. Sci. 32 (Suppl. 1): 66-72.

38. Casida, L. E., W. E. Graves, E. R. Hauser, J. W. Lauderdale, J. W. Riesen, S. Saiduddin and W. J. Tyler. 1968. Studies on the post-partum cow. Univ Wisconsin Res Bull No. 270:1.

39. Chang, C. F. and J. J. Reeves. 1987. Postpartum interval in beef cows shortened by enclomiphene. J. Anim. Sci. 65: 217-223.

40. Chenoweth, P. J. 1983. Sexual behavior of the bull: a review. J Dairy Sci. 66(1):173-9.

41. Chow, P. H., H. Y. Jiang, H. K. Poon, K. H. Lee, and W. S. O. 2003. Embryos sired by males without accessory sex glands induce failure of uterine support: a study of VEGF, MMP and TGF expression in the golden hamster. Anat Embryol (Berl) 206:203-13.

42. Choy, Y. H., J. S. Brinks, and R. M. Bourdon. 2002. Repeated-measure animal models to estimate genetic components of mature weight, hip height, and body condition score. J. Anim. Sci. 80: 2071-2077.

43. Ciccioli, N.H., R. P. Wettemann, L. J. Spicer, C. A. Lents, F. J. White and D. H. Keisler.2003. Influence of body condition at calving and postpartum nutrition on endocrine function and reproductive performance of primiparous beef cows. J. Anim. Sci. 81: 3107-3120.

44. Clemens, L. G., and L. W. Christensen. 1975. Sexual behavior in The behavior of domestic animals. 3rd ed. E.S.E. Hafez, ed. Williams and Wilkins Co., Baltimore, MD.

45. Clemente, P. F. et al. 1978. Effect of precalving nutrition, early weaning, cb-154, and antiprolactin treatment on postpartum interval length in beef cows. J. Anim. Sci. 47: 351-352.

46. Coffey, M. P., G. Simm, W. G. Hill and S. Brotherstone. 2003. Genetic evaluations of dairy bulls for daughter energy balance profiles using linear type scores and body condition score analyzed using random regression. J. Dairy Sci. 86: 2205-2212.

47. Copelin, J. P., M. F. Smith, H. A. Garverick, and R. S. Youngquist. 1987. Effect of the uterus on subnormal luteal function in anestrous beef cows. J. Anim. Sci. 64: 1506-1511. 
48. Copelin, J. P., M. F. Smith, H. A. Garverick, R. S. Youngquist, W. R. McVey Jr, and E. K. Inskeep. 1988. Responsiveness of bovine corpora lutea to prostaglandin f2 alpha: Comparison of corpora lutea anticipated to have short or normal lifespans. J. Anim. Sci. 66: 1236-1245.

49. Crowe, M. A., V. Padmanabhan, M. Mihm, I. Z. Beitins, and J. F. Roche. 1998. Resumption of follicular waves in beef cows is not associated with periparturient changes in follicle-stimulating hormone heterogeneity despite major changes in steroid and luteinizing hormone concentrations. Biol. Reprod. 58: 1445-1450.

50. Dailey, R. A., E. K. Inskeep, and P. L. Lewis. 2002. Pregnancy failures in cattle: a perspective on embryo loss. In: Proceedings of the XVIIIth International Conference on Reproduction of Farm Animals, Slovakia, pp. 1-8.

51. Darwash, A. O., G. E. Lamming, and J. A. Woolliams. 1997. Estimation of genetic variation in the interval from calving to postpartum ovulation of dairy cows. J. Dairy Sci. 80: 1227-1234.

52. Day, M. L., K. Imakawa, A. C. Clutter, P. L. Wolfe, D. D. Zalesky. M. K. Nielsen and J. E. Kinder. 1987. Suckling behavior of calves with dams varying in milk production. J. Anim. Sci. 65: 1207-1212.

53. Day, M. L., S. G. Kurz, K. P. Nephew, M. D. Wright, Y. Hu, S. P. Ford, and W. F. Pope. 1993. Influence of catecholestradiol on short-lived corpora lutea in beef cows. Dom. Anim. Endocrinol. 10: 95-102.

54. DeRouen, S. M., D. E. Franke, D. G. Morrison, W. E. Wyatt, D. F. Coombs, T. W. White, P. E. Humes and B. B. Greene. 1994. Prepartum body condition and weight influences on reproductive performance of first-calf beef cows. J. Anim. Sci. 72: 1119-1125.

55. Diskin, M. G., D. R. Mackey, J. F. Roche and J. M. Sreenan. 2003. Effects of nutrition and metabolic status on circulating hormones and ovarian follicle development in cattle. Anim. Reprod. Sci. 78:345-370. Review.

56. Doepel, L., H. Lapierre and J.J. Kennelly. 2002. Peripartum Performance and Metabolism of Dairy Cows in Response to Prepartum Energy and Protein Intake. J. Dairy Sci. 85: 2315-2334.

57. Donaldson, L. E., J. M. Bassett, and G. D. Thorburn. 1970. Peripheral plasma progesterone concentration of cows during puberty, oestrous cycles, pregnancy and lactation, and the effects of under-nutrition or exogenous oxytocin on progesterone concentration. J. Endocrinol. 48: 599-614.

58. Dunn, T. G. and C. C. Kaltenbach. 1980. Nutrition and the postpartum interval of the ewe, sow and cow. J. Anim. Sci. 51 (Suppl. 2): 29-39. Review. 
59. Dunn, T. G., J. E. Ingalls, D. R. Zimmerman, and J. N. Wiltbank. 1969. Reproductive performance of 2-year-old hereford and angus heifers as influenced by pre- and post-calving energy intake. J. Anim. Sci. 29: 719-726.

60. Edgerton, L. A. 1980. Effect of lactation upon the postpartum interval. J. Anim. Sci. 51 (Suppl. 2): 40-52. Review.

61. Encinias, A. M. and G. Lardy. 2000. Body Condition Scoring I: Managing your cow herd through body condition scoring. NDSU Extension Service. AS-1026. Available at: http://www.ext.nodak.edu/extpubs/ansci/beef/as1026w.htm. Accessed April 2005.

62. Fahmi, H. A., A. G. Hunter, R. J. Markham, and B. E. Seguin. 1995. Immunosuppressive activity of bovine seminal plasma on bovine lymphocytes in vitro. J Dairy Sci 68:2315-21.

63. Fernandez, D. L., J. G. Berardinelli, R. E. Short and R. Adair. 1996. Acute and chronic changes on LH secretion, and postpartum interval to estrus in first-calf suckled beef cows exposed continuously or intermittently to mature bulls. J. Anim. Sci. 74: 1098-1100.

64. Ferrell, C. L., and T. G. Jenkins. 1996. Relationships between body condition score and empty body weight, water, fat, protein, and energy percentages in mature beef cows of diverse breeds. J. Anim. Sci. 74(Suppl. 1): 245 (Abstr.).

65. Fonseca, F. A., J. H. Britt, B. T. McDaniel, J. C. Wilk, and A. H. Rakes. 1983. Reproductive traits of holsteins and jerseys. Effects of age, milk yield, and clinical abnormalities on involution of cervix and uterus, ovulation, estrous cycles, detection of estrus, conception rate, and days open. J. Dairy Sci. 66: 11281147.

66. Foote, W. D., and D. W. Peterson. 1968. Relationships between side of pregnancy and side of subsequent ovarian activities in beef and dairy cattle. J. Reprod. Fertil. 16: 415-421.

67. Foote, W. D., and J. E. Hunter. 1964. Post-partum intervals of beef cows treated with progesterone and estrogen. J. Anim. Sci. 23: 517.

68. Foster, J. P., G. E. Lamming, and A. R. Peters. 1980. Short-term relationships between plasma LH, FSH and progesterone concentrations in post-partum dairy cows and the effect of GnRH injection. J. Reprod. Fertil. 59: 321-327.

69. Freetly, H. C., and J. A. Nienaber. 1998. Efficiency of energy and nitrogen loss and gain in mature cows. J Anim. Sci. 76:896-905.

70. Funston, R. N. 2004. Fat supplementation and reproduction in beef females. J. Anim. Sci. 82(E. Suppl.): E154-E161. 
71. Garcia-Winder, M., K. Imakawa, M. L. Day, D. D. Zalesky, R. J. Kittok and J. E. Kinder. 1984. Effect of suckling and ovariectomy on the control of luteinizing hormone secretion during the postpartum period in beef cows. Biol. Reprod. 31: 771-778.

72. Garcia-Winder, M., P. E. Lewis, D. R. Deaver, V. G. Smith, G. S. Lewis, and E. K. Inskeep. 1986. Endocrine profiles associated with life span of induced corpora lutea in postpartum beef cows. J. Anim. Sci. 62: 1353-1362.

73. Geary, T. W. 2003. Management of young cows for maximum reproductive performance. USDA-ARS Fort Keogh, Miles City, MT. http://www.beefimprovement.org/proceedings/03proceedings/Geary.pdf Accessed August 2008.

74. Gier, H. T., and G. B. Marion. 1968. Uterus of the cow after parturition: involutional changes. Am. J. Vet. Res. 29: 83-96.

75. Goodman, R. L. 1988. Neuroendocrine control of the ovine estrous cycle. In: E. Knobil and J. D. Neill (Ed.) The physiology of Reproduction. Raven Press, New York.

76. Graves, W. E., J. W. Lauderdale, E. R. Hauser and L. E. Casida 1968. Relation of postpartum interval to pituitary gonadotropins. Ovarian follicular development and fertility in beef cows. Univ. of Wisconsin Res. Bull. 270: 22-26.

77. Grimard, B., P. Humblot, A. A. Ponter, J. P. Mialot, D. Sauvant and M. Thibier. 1995. Influence of postpartum energy restriction on energy status, plasma LH and oestradiol secretion and follicular development in suckled beef cows. J. Reprod. Fertil. 104: 173-179.

78. Grimes, J. F. and B. Turner. 1991. Early weaning of fall-born beef calves: I. Preweaning calf and cow performance. J. Prod. Agric. 4: 464-468.

79. Grings, E. E., R. E. Short, K. D. Klement, T. W. Geary, M. D. MacNeil, M. R. Haferkamp, and R. K. Heitschmidt. 2005. Calving system and weaning age effects on cow and preweaning calf performance in the Northern Great Plains. J. Anim. Sci. 83: 2671-2683.

80. Grings, E. E., R. E. Short, K. D. Klement, T. W. Geary, M. D. MacNeil, M. R. Haferkamp, and R. K. Heitschmidt. 2005. Calving system and weaning age effects on cow and preweaning calf performance in the Northern Great Plains. J. Anim. Sci. 83: 2671-2683.

81. Grummer, R. R., D. G. Mashek, and A. Hayirli. 2004. Dry matter intake and energy balance in the transition period. Vet. Clin. North Am. Food Anim. Pract. 20(3): 447-470. 
82. Guilbault, L. A., W. W. Thatcher, M. Drost, and S. M. Hopkins. 1984. Source of f series prostaglandins during the early postpartum period in cattle. Biol. Reprod. 31: 879-887.

83. Gwathmey, T. M., G. G. Ignotz, and S. S. Suarez. 2003. PDC-109 (BSP-A1/A2) promotes bull sperm binding to oviductal epithelium in vitro and may be involved in forming the oviductal sperm reservoir. Biol Reprod. 69(3):809-15.

84. Gwathmey, T. M., G. G. Ignotz, J. L. Mueller, P. Manjunath, and S. S. Suarez. 2006. Bovine seminal plasma proteins PDC-109, BSP-A3, and BSP-30-kDa share functional roles in storing sperm in the oviduct. Biol Reprod. 75(4):501-7.

85. Hammond, J. 1927. The physiology of reproduction in the cow. University Press, Cambridge.

86. Hammond, J., Jr. 1944. On the breeding season in the sheep. J. Agric. Sci. 34: 97105.

87. Hansen, P. J. and E. R. Hauser. 1984. Photoperiodic alteration of postpartum reproductive function in suckled cows. Theriogenology 22: 1-14.

88. Hardin, R. 1990. Using body condition scoring in beef cattle management. C-817. University of Georgia College of Agricultural and Environmental Sciences, Cooperative Extension Service.

89. Harpster, H. W., J. W. Comerford, and L. L. Wilson. 1998. Nutrition of grazing beef cattle. Proceedings from the Grazing in the Northeast Workshop, Camp Hill, PA. NRAES-113.

90. Hauser, E. R. 1984. Seasonal effects on female reproduction in the bovine (Bos Taurus) (European breeds). Theriogenology 21: 150-169.

91. Henricks, D. M., J. F. Dickey, J. R. Hill, and W. E. Johnston. 1972. Plasma estrogen and progesterone levels after mating, and during late pregnancy and postpartum in cows. Endocrinol. 90: 1336-1342.

92. Hess, B. W., S. L. Lake, E. J. Scholljegerdes, T. R. Weston, V. Nayigihugu, J. D. C. Molle, and G. E. Moss. 2005. Nutritional controls of beef cow reproduction. J. Anim. Sci. 83(E. Suppl.):E90-E106.

93. Holaskova, Ida (2007). I Distribution of Transforming Growth Factor Beta 1, TGF receptor II and Decorin in the Sheep Uterus Shortly After Breeding, II Effect of TGF Beta 1 on Gene Expression in the Sheep Uterus at the Time of Embryo Attachment, III Concentration of TGF Beta 1, 2, and 3 in Beef Bull and Ram Seminal Plasma, Dissertation, West Virginia University, [On-line Abstract]. Available: https://eidr.wvu.edu/etd/documentdata.eTD?documentid=5373. 
94. Hornick, J.L., C. Van Eenaeme, O. Gerard, I. Dufrasne, and L. Istasse. 2000. Mechanisms of reduced and compensatory growth. Dom. Anim. Endocrinol. 19 (2): 121-132.

95. Houghton, P. L., R. P. Lemenager, L. A. Horstman, K. S. Hendrix, and G. E. Moss.1990a. Effects of body composition, pre- and postpartum energy level and early weaning on reproductive performance of beef cows and preweaning calf gain. J. Anim. Sci. 68: 1438-1446.

96. Houghton, P. L., R. P. Lemenager, K. S. Hendrix, G. E. Moss, and T. S. Stewart. 1990b. Effects of body composition, pre- and postpartum energy intake and stage of production of energy utilization by beef cows. J. Anim. Sci. 68: 1447-1456.

97. Ilzecka J., Stelmasiak Z., Dobosz B. 2002. Transforming growth factor-beta 1 (TGF-beta 1) in patients with amyotrophic lateral sclerosis. Cytokine, 20 (5): 239243.

98. Ingvartsen, K. L. and J. B. Andersen. 2000. Integration of metabolism and intake regulation: a review focusing on periparturient animals. J Dairy Sci. 83: 15731597. Review.

99. Inskeep, E. K. 1995. Factors that affect fertility during oestrous cycles with short or normal luteal phases in postpartum cows. J. Reprod. Fertil. (Suppl.) 49: 493503.

100. Inskeep, E. K., T. D. Braden, P. E. Lewis, M. Garcia-Winder, and G. D. Niswender. 1988. Receptors for luteinizing hormone and follicle-stimulating hormone in largest follicles of postpartum beef cows. Biol. Reprod. 38: 587-591.

101. Inskeep, E.K., and R. A. Dailey. 2005. Embryonic death in cattle. Vet Clin North Am Food Anim Pract. 21(2):437-61.

102. Jagger, J. P., A. R. Peters, and G. E. Lamming. 1987. Hormone responses to lowdose gnrh treatment in post-partum beef cows. J. Reprod. Fertil. 80: 263-269.

103. Jobim, M. I., E. R. Oberst, C. G. Salbego, D. O. Souza, V. B. Wald, F. Tramontina, and R. C. Mattos. 2004. Two-dimensional polyacrylamide gel electrophoresis of bovine seminal plasma proteins and their relation with semen freezability. Theriogenology 61(2-3):255-66.

104. Johnson, S. K., R. P. Del Vecchio, E. C. Townsend, and E. K. Inskeep. 1992. Role of prostaglandin $\mathrm{f} 2$ alpha in follicular development and subsequent luteal life span in early postpartum beef cows. Domest. Anim. Endocrinol. 9: 49-56.

105. Jolly, P. D., S. McDougall, L. A. Fitzpatrick, K. L. Macmillan, and K. W. Entwistle. 1995. Physiological effects of undernutrition on postpartum anoestrus in cows. J. Reprod. Fertil. (Suppl.) 49: 477-492. 
106. Jones, A. G., G. I. Moore, C. Kvarnemo, D. Walker, and J. C. Avise. 2003. Sympatric speciation as a consequence of male pregnancy in seahorses. Proc Natl Acad Sci 100(11):6598-603.

107. Jorritsma, R., P. Langendijk, T.A.M. Kruip, T.H. Wensing, and J.P.T.M. Noordhuizen. 2005. Associations between Energy Metabolism, LH Pulsatility and First Ovulation in early Lactating Cows. Reprod. Domest. Anim. 40: 68-72.

108. Jorritsma, R., T. Wensing, T. A. Kruip, P. L. Vos, and J. P. Noordhuizen. 2003. Metabolic changes in early lactation and impaired reproductive performance in dairy cows. Vet. Res. 34: 11-26. Review.

109. Kaim, M., Y. Folman, H. Neumark, and W. Kaufmann. 1983. The effect of protein intake and lactation number on post- partum body weight loss and reproductive performance of dairy cows. Anim. Prod. 37: 229.

110. Katila, T. 1996. Uterine defense mechanisms in the mare. Anim Reprod Sci 42:197-204.

111. Kenneway, D. J., E. A. Dunstan, and L. D. Staples. 1987. Photoperiodic control of the onset of breeding activity and fecundity in ewes. In: G. D. Niswender (Ed.) Reproduction in Domestic Ruminants. The Dorset Press, Dorchester, UK.

112. Kieborz-Loos, K. R., H. A. Garverick, D. H. Keisler, S. A. Hamilton, B. E. Salfen, R. S. Youngquist, and M. F Smith. 2003. Oxytocin-induced secretion of prostaglandin F2 $\alpha$ in postpartum beef cows: Effects of progesterone and estradiol$17 \beta$ treatment. J. Anim. Sci. 2003. 81: 1830-1836.

113. Killian, G. J., D. A. Chapman, and L. A. Rogowski.1993. Fertility-associated proteins in Holstein bull seminal plasma. Biol Reprod. 49(6):1202-7.

114. King, G. J., J. F. Hurnik, and H. A. Robertson. 1976. Ovarian function and estrus in dairy cows during early lactation. J. Anim. Sci. 42: 688-692.

115. Kiracofe, G. H. 1980. Uterine involution: Its role in regulating postpartum intervals. J. Anim. Sci. 51 (Suppl. 2): 16-28.

116. Kiracofe, G. H., R. R. Schalles, and G. B. Marion. 1969. Effect of wintering ration on reproductive phenomena in beef cows on range. Kansas Agr. Exp. Sta. Bull. 529.

117. Koc, E. C., W. Burkhart, K. Blackburn, M. B. Moyer, D. M. Schlatzer, A. Moseley, and L. L. Spremulli. 2001. The large subunit of the mammalian mitochondrial ribosome. Analysis of the complement of ribosomal proteins present. J Biol Chem. 23;276(47):43958-69. 
118. Lamb, G. C., B. L. Miller, J. M. Lynch, K. E. Thompson, J. S. Heldt, C. A. Loest, D. M. Grieger, and J. S. Stevenson. 1999. Twice daily suckling but not milking with calf presence prolongs postpartum anovulation. J. Anim. Sci. 77: 2207-2218.

119. Lamb, G. C., J. M. Lynch, D. M. Grieger, J. E. Minton, and J. S. Stevenson. 1997. Ad libitum suckling by an unrelated calf in the presence or absence of a cow's own calf prolongs postpartum anovulation. J. Anim. Sci. 75: 2762-2769.

120. Lamming, G. E., D. C. Wathes, and A. R. Peters. 1981. Endocrine patterns of the post-partum cow. J. Reprod. Fertil. (Suppl.) 30: 155-170.

121. Laster, D. B., H. A. Glimp, L. V. Cundiff, and K. E. Gregory. 1973. Factors affecting dystoia and the effects of dystocia on subsequent reproduction in beef cattle. J. Anim. Sci. 36: 695-705.

122. Lents, C. A., R. P. Wettemann, F. J. White, I. Rubio, N. H. Ciccioli, L. J. Spicer, D. H. Keisler, and M. E. Payton. 2005. Influence of nutrient intake and body fat on concentrations of insulin-like growth factor-I, insulin, thyroxine, and leptin in plasma of gestating beef cows. J. Anim. Sci. 83: 586-596.

123. Letterio, J. J. and A. B. Roberts. 1998. Regulation of immune responses by TGFß. Annu Rev Immunol 16:137-161.

124. Lindell, J. O., H. Kindahl, L. E. Edqvist, and G. Tufvesson. 1982. Effect of hysterectomy on the postpartum prostaglandin levels in the cow. Acta Vet. Scand. 23: $144-146$.

125. Lishman, A. W., S. M. Allison, R. L. Fogwell, R. L. Butcher, and E. K. Inskeep. 1979. Follicular development and function of induced corpora lutea in underfed postpartum anestrous beef cows. J. Anim. Sci. 48: 867-875.

126. Lofstedt, R. M., J. G. Manns, B. D. Murphy, W. D. Humphrey, and R. J. Mapletoft. 1981. Influence of gnrh infusion on endocrine parameters and duration of postpartum anestrus in beef cows. Theriogenology 15: 359-377.

127. Lopez-Gatius, F., J. Yaniz and D. Madriles-Helm. 2003. Effects of body condition score and score change on the reproductive performance of dairy cows: a metaanalysis. Theriogenology. 59: 801-812.

128. Loras, B., F. Vételé, A. El Malki, J. Rollet, J. C. Soufir, and M. Benahmed. 1999. Seminal transforming growth factor-beta in normal and infertile men. Hum Reprod. 14(6):1534-9.

129. Lowry, O. H., N. H. Rosebrough, A. L. Farr, and R. J. Randall. 1951. Protein measurement with the Folin phenol reagent. J Biol Chem. 193(1):265-75.

130. Lucy, M. C. 2001. Reproductive loss in high-producing dairy cattle: Where will it end? J. Dairy Sci. 84:1277-1293. 
131. Lucy, M. C. 2003. Mechanisms linking nutrition and reproduction in postpartum cows. Reprod. (Suppl.) 61: 415-427.

132. Lucy, M. C., W. J.Weber, L. H. Baumgard, B. S. Seguin,A. T.Koenigsfeld, L. B. Hansen, H. Chester-Jones, and B. A. Crooker. 1998. Reproductive endocrinology of lactating dairy cows selected for increased milk production. J. Anim. Sci. 76(Suppl. 1):296. (Abstr.).

133. Macmillan, K. L. 1983. Postpartum interval to estrus in monozygous twin cows and possible effects of maternal bonding. NZ J. Agric. Res. 26: 451-454.

134. Macmillan, K. L., I. J. Lean, and C. T. Westwood. 1996. The effects of lactation on the fertility of dairy cows. Aust. Vet. J. 73: 141-147.

135. Madej, A., H. Kindahl, W. Woyno, L. E. Edqvist, and R. Stupnicki. 1984. Blood levels of 15-keto-13, 14-dihydroprostaglandin $\mathrm{f}$ (2alpha) during the postpartum period in primiparous cows. Theriogenology 21:279-287.

136. Manjunath, P., S. Soubeyrand, L. Chandonnet, and K. D. Roberts.1994. Major proteins of bovine seminal plasma inhibit phospholipase A2. Biochem J. 303:1218.

137. Mann, G. E., and G. E. Lamming. 2000. The role of sub-optimal preovulatory oestradiol secretion in the aetiology of premature luteolysis during the short oestrous cycle in the cow. Anim. Reprod. Sci. 64: 171-180.

138. Marlowe, T. J., and G. A. Morrow. 1985. Heritabilities and phenotypic, genetic and environmental correlations for weight, grade and condition of Angus cows. J. Anim. Sci. 60: 82-88.

139. Marston, T. T., K. S. Lusby, R. P. Wettemann and H. T. Purvis. 1995. Effects of feeding energy or protein supplements before or after calving on performance of spring-calving cows grazing native range. J. Anim. Sci. 73: 657-664.

140. Martin, J. L., R. J. Rasby, D. R. Brink, R. U. Lindquist, D. H. Keisler, and S. D. Kachman. 2005. Effects of supplementation of whole corn germ on reproductive performance, calf performance, and leptin concentration in primiparous and mature beef cows. J. Anim. Sci. 83: 2663-2670.

141. Mattos, R., C. R. Staples, and W. W. Thatcher. 2000. Effects of dietary fatty acids on reproduction in ruminants. Rev. Reprod. 5: 38-45.

142. Maxwell, W. M. C., S. P. de Graaf, R. El-Hajj Ghaoui, and G. Evans. 2007. Seminal plasma effects on sperm handling and female fertility. Soc Reprod Fertil Suppl. 64:13-38. Review.

143. Mazzieri, R., J. S. Munger, and D. B. Rifkin. 2000. Measurement of active TGFbeta generated by cultured cells. Methods Mol Biol. 142:13-27. 
144. McDougall, S., C. R. Burke, K. L. MacMillan, and N. B. Williamson. 1995. Patterns of follicular development during periods of anovulation in pasture-fed dairy cows after calving. Res. Vet. Sci. 58: 212-216.

145. Melton, A. A., J. K. Riggs, L. A. Nelson and T. C. Cartwright. 1967. Milk production, composition and calf gains of Angus, Charolais and Hereford cows. J. Anim. Sci. 26: 804-809.

146. Montiel, F. and C. Ahuja. 2005. Body condition and suckling as factors influencing the duration of postpartum anestrus in cattle: a review. Anim. Reprod. Sci. 85: 1-26. Review.

147. Moreira, F., C. A. Risco, M. F. A. Pires, J. D. Ambrose, M. Drost, and W. W. Thatcher. 2000. Use of bovine somatotropin in lactating dairy cows receiving timed artificial insemination. J Dairy Sci 83:1245-55.

148. Moreira, F., C. Orlandi, C. A. Risco, R. Mattos, F. Lopes, and W. W. Thatcher. 2001. Effects of presynchronization and bovine somatotropin on pregnancy rates to a timed artificial insemination protocol in lactating dairy cows. J Dairy Sci 84:1646-59.

149. Morris, S. T., P. C. H. Morel, and P. R. Kenyon. 2006. The effect of individual liveweight and condition of beef cows on their reproductive performance and birth and weaning weights of calves. NZ. Vet. J. 56: 96-100.

150. Morrison, D. G., J. C. Spitzer, and J. L. Perkins. 1999. Influence of prepartum body condition score change on reproduction in multiparous beef cows calving in moderate body condition. J. Anim. Sci. 77: 1048-1054.

151. Morrow, D. A., S. J. Roberts, K. McEntee and H. G. Gray. 1966. Postpartum ovarian activity and uterine involution in dairy cattle. J. Amer. Vet. Med. Assoc. 149: 1596-1609.

152. Mortarino, M., G. Tedeschi, A. Negri, F. Ceciliani, L. Gottardi, G. Maffeo, and S. Ronchi. 1998. Two-dimensional polyacrylamide gel electrophoresis map of bull seminal plasma proteins. Electrophoresis. 19(5):797-801.

153. Moss, G. E., M. E. Crowder, and T. M. Nett. 1981. GnRH-receptor interaction. VI. Effect of progesterone and estradiol on hypophyseal receptors for GnRH, and serum and hypophyseal concentrations of gonadotropins in ovariectomized ewes. Biol. Reprod. 25: 938-944.

154. Moura, A. A., D. A. Chapman, and G. J. Killian. 2007. Proteins of the accessory sex glands associated with the oocyte-penetrating capacity of cauda epididymal sperm from holstein bulls of documented fertility. Mol Reprod Dev. 74(2):21422. 
155. Moura, A. A., H. Koc, D. A. Chapman, and G. J. Killian. 2006. Identification of proteins in the accessory sex gland fluid associated with fertility indexes of dairy bulls: a proteomic approach. J Androl. 27(2):201-11.

156. Mukasa-Mugerwa, E., A. Tegegne, R. Franceschini. 1991. Influence of suckling and continuous cow-calf association on the resumption of post-partum ovarian function in Bos indicus cows monitored by plasma progesterone profiles. Reprod. Nutr. 31: 241-247.

157. Munger, J. S., J. G. Harpel, P. E. Gleizes, R. Mazzieri, I. Nunes, and D. B. Rifkin. 1997. Latent transforming growth factor-beta: structural features and mechanisms of activation. Kidney Int. 51(5):1376-82.

158. Murphy, M. G., M. P. Boland, and J. F. Roche. 1990. Pattern of follicular growth and resumption of ovarian activity in post-partum beef suckler cows. J. Reprod. Fertil. 90: 523-533.

159. Murray, F. A., A. P. Grifo, and C. F. Parker. 1983. Increased litter size in gilts by intrauterine infusion of seminal and sperm antigens before breeding. J Anim Sci 56:895-900.

160. Myers, S. E., D. B. Faulkner, F. A. Ireland, and D. F. Parrett. 1999b. Comparison of three weaning ages on cow-calf performance and steer carcass traits. J. Anim. Sci. 77: 323-329.

161. Myers, S. E., D. B. Faulkner, F. A. Ireland, L. L. Berger, and D. F. Parrett. 1999a. Production systems comparing early weaning to normal weaning with or without creep feeding for beef steers. J. Anim. Sci. 77: 300-310.

162. Nebel, R. L., and M. L. McGilliard. 1993. Interactions of high milk yield and reproductive performance in dairy cows. J Dairy Sci. 76(10):3257-68.

163. Nett, T. M., D. Cermak, T. Braden, J. Manns, and G. Niswender. 1987. Pituitary receptors for gnrh and estradiol, and pituitary content of gonadotropins in beef cows. I. Changes during the estrous cycle. Domest. Anim. Endocrinol. 4: 123132.

164. Neville, W. E., Jr., K. L. Richardson, D. J. Williams III, B. G. Mullinix, Jr., and P. R. Utley. 1990. Subsequent reproduction and calf performance of nonpregnant cows compared with pregnant cows and replacement females. J. Anim. Sci. 68: 2188-2197.

165. Northcutt, S. L., D. E. Wilson, and R. L. Willham. 1992. Adjusting weight for body condition score in Angus cows. J. Anim. Sci. 70: 1342-1345.

166. O, W. S., H. Q. Chen, and P. H. Chow. 1998. Effects of male accessory sex gland secretions on early embryonic development in the golden hamster. J Reprod Fertil 84: 341-344. 
167. Odde, K. G., H. S. Ward, G. H. Kiracofe, R. M. McKee, and R. J. Kittok. 1980. Short estrous cycles and associated serum progesterone levels in beef cows. Theriogenology 14: 105-112.

168. O'Leary, S., M. J. Jasper, G. M. Warnes, D. T. Armstrong, and S. A. Robertson. 2004. Seminal plasma regulates endometrial cytokine expression, leukocyte recruitment and embryo development in the pig. Reproduction 128:37-47.

169. Omer, F. M., J. B. de Souza, P.H. Corran, A. A. Sultan, and E. M. Riley. 2003. Activation of transforming growth factor beta by malaria parasite-derived metalloproteinases and a thrombospondin-like molecule. J Exp Med. 198(12):1817-27.

170. Osoro, K. and I. A. Wright. 1992. The effect of body condition, live weight, breed, age, calf performance, and calving date on reproductive performance of spring-calving beef cows. J. Anim. Sci. 70: 1661-1666.

171. Ottobre, A. L., and P. E. Lewis. 1983. Selection and development of replacement heifers. West Virginia Univ Res Bull No. 125. W V Ag. Exp. Stn. Morgantown.

172. Oxenreider, S. L. and W. C. Wagner. 1971. Effect of lactation and energy intake on postpartum ovarian activity in the cow. J. Anim. Sci. 33: 1026-1031.

173. Pang, S. F., P. H. Chow, and T. M. Wong. 1979. The role of the seminal vesicles, coagulating glands and prostate glands on the fertility and fecundity of mice. $\mathrm{J}$ Reprod Fertil 56:129-32.

174. Pate, F. M., J. R. Crockett, and J. D. Phillips. 1985. Effect of calf weaning age and cow supplementation on cow productivity. J. Anim. Sci. 61: 343-348.

175. Peddinti, D., B. Nanduri, A. Kaya, J. M. Feugang, S. C. Burgess, and E. Memili. 2008. Comprehensive proteomic analysis of bovine spermatozoa of varying fertility rates and identification of biomarkers associated with fertility. BMC Syst Biol. 2(19):1-14.

176. Perez-Hernandez, P., M. Garcia-Winder, J. Gallegos-Sanchez. 2002. Postpartum anoestrus is reduced by increasing the within-day milking to suckling interval in dual purpose cows. Anim. Reprod. Sci. 73: 159-168.

177. Perry, G. A., M. F. Smith, M. C. Lucy, J. A. Green, T. E. Parks, M. D. MacNeil, A. J. Roberts, and T. W. Geary. 2005. Relationship between follicle size at insemination and pregnancy success. Proc Natl Acad Sci. 102(14):5268-73.

178. Perry, R. C., L. R. Corah, R. C. Cochran, W. E. Beal, J. S. Stevenson, J. E. Minton, D. D. Simms, and J. R. Brethour. 1991. Influence of dietary energy on follicular development, serum gonadotropins, and first postpartum ovulation in suckled beef cows. J. Anim. Sci. 69: 3762-3773. 
179. Pryce, J. E., M. P. Coffey, and G. Simm. 2001. The relationship between body condition score and reproductive performance. J. Dairy Sci. 84: 1508-1515.

180. Queen, K., C. B. Dhabuwala, and C. G. Pierrepoint. 1981. The effect of the removal of the various accessory sex glands on the fertility of male rats. J Reprod Fertil. 62: 423-426.

181. Rae, D. O., W. E. Kunkle, P. J. Chenoweth, R. S. Sand and T. Tran. 1993. Relationship of parity and body condition score to pregnancy rates in Florida beef cattle. Theriogenology 39: 1143-1152.

182. Ramirez-Godinez, J. A., G. H. Kiracofe, R. R. Schalles, and G. D. Niswender. 1982b. Endocrine patterns in the postpartum beef cow associated with weaning: A comparison of the short and subsequent normal cycles hormone levels. J. Anim. Sci. 55: 153-158.

183. Ramirez-Godinez, J. A., G. H. Kirakofe, D. L. Carnahan, M. F. Spire, K. B. Beeman, J. S. Stevenson, and R. R. Schalles. 1982a. Evidence for ovulation and fertilization in beef cows with short estrous cycles. Theriogenology 17: 409-414.

184. Randel, R. D. 1990. Nutrition and postpartum rebreeding in cattle. J. Anim. Sci. 68: 853-862. Review.

185. Randel, R. D., R. E. Short, D. S. Christensen, and R. A. Bellows. 1975. Effect of clitoral massage after artificial insemination on conception in the bovine. J. Anim. Sci. 40:119.

186. Rastani, R. R., S. M. Andrew, S. A. Zinn and C. J. Sniffen. 2001. Body composition and estimated tissue energy balance in Jersey and Holstein cows during early lactation. J. Dairy Sci. 84: 1201-1209.

187. Renquist, B. J., J. W. Oltjen, R. D. Sainz, and C. C. Calvert. 2006. Effects of age on body condition and production parameters of multiparous beef cows. J. Anim. Sci. 84: 1890-1895.

188. Rhinehart, J. D., M. J. Starbuck-Clemmer, J. A. Flores, R. A. Milvae, J. Yao, D. H. Poole, and E. K. Inskeep. Low peripheral progesterone and late embryonic/early fetal loss in suckled beef and lactating dairy cows. Theriogenology. 2008 Sep 20. [Epub ahead of print]

189. Rhodes, F. M., L. A. Fitzpatrick, K. W. Entwistle, and G. De'ath. 1995. Sequential changes in ovarian follicular dynamics in bos indicus heifers before and after nutritional anoestrus. J. Reprod. Fertil. 104: 41-49.

190. Rhodes, F. M., S. McDougall, C. R. Burke, G. A. Verkerk, and K. L. Macmillan. 2003. Invited review: Treatment of cows with an extended postpartum anestrous interval. J. Dairy Sci. 86: 1876-1894. 
191. Rhodes, M., J. H. Brendemuhl, and P. J. Hansen. 2006. Litter characteristics of gilts artificially inseminated with transforming growth factor-beta. Am. J. Reprod. Immunol. 56:153-6.

192. Richards, M. W., J. C. Spitzer and M. B. Warner. 1986. Effect of varying levels of postpartum nutrition and body condition at calving on subsequent reproductive performance in beef cattle. J. Anim. Sci. 62: 300-306.

193. Richardson, A. T., T. G. Martin, and R. E. Hunsley. 1978. Weaning age of Angus heifer calves as a factor influencing calf and cow performance. J. Anim. Sci. 47: 6-14.

194. Riesen, J. W., S. Saiduddin, W. J. Tyler, and L. E. Casida. 1968. Relation of postpartum interval to corpus luteum development, pituitary prolactin activity, uterine involution in dairy cows. (Effect of suckling). Studies on the postpartum cow. Univ Wisconsin Res Bull 270:27-41.

195. Roberson, M. S., M. W. Wolfe, T. T. Stumpf, L. A. Werth, A. S. Cupp, N. Kojima, P. L. Wolfe, R. J. Kittok, and J. E. Kinder. 1991. Influence of growth rate and exposure to bulls on age at puberty in beef heifers. J. Anim. Sci. 69: 2092-2098.

196. Roberson, M. S., R. P. Ansotegui, J. G. Berardinelli, R. W. Whitman, and M. J. McInerney. 1987. Influence of biostimulation by mature bulls on occurrence of puberty in beef heifers. J. Anim. Sci. 64: 1601-1605.

197. Robertson, S. A. 2005. Seminal plasma and male factor signalling in the female reproductive tract. Cell Tissue Res. 322(1):43-52.

198. Robertson, S. A. 2007a. Seminal fluid signaling in the female reproductive tract: lessons from rodents and pigs. J. Anim. Sci. Suppl. 85:E36-44.

199. Robertson, S. A. 2007b. GM-CSF regulation of embryo development and pregnancy. Cytokine Growth Factor Rev. 18:287-98.

200. Robertson, S. A., C. Sjoblom, M. J. Jasper, R. J. Norman, and R. F. Seamark. 2001. Granulocyte-macrophage colony-stimulating factor promotes glucose transport and blastomere viability in murine preimplantation embryos. Biol. Reprod. 64:1206-15.

201. Robertson, S. A., S. O'Leary, and D. T. Armstrong. 2006. Influence of semen on inflammatory modulators of embryo implantation. Soc. Reprod. Fertil. Suppl. 62:231-45.

202. Robertson, S. A., V. J. Mau, K. P. Tremellen, and R. F. Seamark. 1996. Role of high molecular weight seminal vesicle proteins in eliciting the uterine inflammatory response to semen in mice. J. Reprod. Fertil. 107:265-77. 
203. Robertson, S. A., W. V. Ingman, S. O'Leary, D. J. Sharkey, and K. P. Tremellen. 2002. Transforming growth factor beta--a mediator of immune deviation in seminal plasma. J. Reprod. Immunol. 57:109-28.

204. Robinson, D. L., C. A. McDonald, K. Hammond, and J. W. Turner. 1992. Live animal measurement of carcass traits by ultrasound: Assessment and accuracy of sonographers. J. Anim. Sci. 70: 1667-1676.

205. Roche, J. R., E. S. Kolver, and J. K. Kay. 2005. Influence of precalving feed allowance on periparturient metabolic and hormonal responses and milk production in grazing dairy cows. J. Dairy Sci. 88: 677-689.

206. Rozeboom, K. J., M. H. Troedsson, and B. G. Crabo. 1998. Characterization of the post-mating uterine inflammatory response in the gilt. J. Reprod. Fertil. 114:195-9.

207. Rozeboom, K. J., M. H. Troedsson, T. W. Molitor, and B. G. Crabo. 1999. The effect of spermatozoa and seminal plasma on leukocyte migration into the uterus of gilts. J. Anim. Sci. 77:2201-6.

208. Rutter, L. M., and Randel R. D. 1984. Postpartum nutrient intake and body condition: effect on pituitary function and onset of estrus in beef cattle. J. Anim. Sci. 58: 265-274.

209. Sasser, R. G., R. J. Williams, R. C. Bull, C. A. Ruder, and D. G. Falk. 1988. Postpartum reproductive performance in crude protein-restricted beef cows: return to estrus and conception. J. Anim. Sci. 66: 3033-9.

210. Savio, J. D., M. P. Boland, N. Hynes, and J. F. Roche. 1990. Resumption of follicular activity in the early post-partum period of dairy cows. J. Reprod. Fertil. 88: 569-579.

211. Schroder, U. J., and R. Staufenbiel. 2006. Invited review: Methods to determine body fat reserves in the dairy cow with special regard to ultrasonographic measurement of backfat thickness. J. Dairy Sci. 89: 1-14.

212. Scott, J. L., N. Ketheesan, and P. M. Summers. 2005. The post-insemination inflammatory response in the ewe. Reproduction, Fertility and Development 17(Suppl.):121. Abstr.

213. Shipka, M. P., and L. C. Ellis. 1998. No effects of bull exposure on expression of estrous behavior in high-producing dairy cows. Appl. Anim. Behav. Sci. 57: 1-7.

214. Shipka, M. P., and L. C. Ellis. 1999. Effects of bull exposure on postpartum ovarian activity of dairy cows. Anim. Reprod. Sci. 54: 237-244. 
215. Short, R. E., R. A. Bellows, E. L. Moody, and B. E. Howland. 1972. Effects of suckling and mastectomy on bovine postpartum reproduction. J. Anim. Sci. 34: 70-74.

216. Short, R. E., R. A. Bellows, R. B. Staigmiller, J. G. Berardinelli, and E. E. Custer. 1990. Physiological mechanisms controlling anestrus and infertility in postpartum beef cattle. J. Anim. Sci. 68: 799-816.

217. Short, R. E., R. D. Randel, and R. A. Bellows. 1974. Factors affecting reproduction in the postpartum cow. J. Anim. Sci. 39: 226(Abstr.).

218. Short, R. E., R. D. Randel, R. B. Staigmiller and R. A. Bellows. 1979. Factors affecting estrogen-induced LH release in the cow. Biol. Reprod. 21: 683-689.

219. Sletmoen-Olson, K. E., J. S. Caton, K. C. Olson, D. A. Redmer, J. D. Kirsch and L. P. Reynolds. 2000. Undegraded intake protein supplementation: II. Effects on plasma hormone and metabolite concentrations in periparturient beef cows fed low-quality hay during gestation and lactation. J. Anim. Sci. 78: 456-463.

220. Smith, M. F., W. C. Burrell, L. D. Shipp, L. R. Sprott, W. N. Songster and J. N. Wiltbank. 1979. Hormone treatments and use of calf removal in postpartum beef cows. J. Anim. Sci. 48: 1285-1294.

221. Smith, V. G., V. G. Smith, J. R. Chenault, J. F. McAllister, and J. W. Lauderdale. 1987. Response of postpartum beef cows to exogenous progestogens and gonadotropin releasing hormone. J. Anim. Sci. 64: 540-551.

222. Spitzer, J. C. 1998. Influence of biostimulation on enhancement of reproductive performance in beef cattle. Clemson Univ. Beef Cattle Info. Database BC-2012. Available: http://www.clemson.edu/edisto/beef-db/beef-db.htm. Accessed June 2007.

223. Spitzer, J. C., D.G. Morrison, R. P. Wettemann, and L. C. Faulkner. 1995. Reproductive responses and calf birth and weaning weights as affected by body condition at parturition and postpartum weight gain in primiparous beef cows. J. Anim. Sci. 73: 1251-1257.

224. Stagg, K., L. J. Spicer, J. M. Sreenan, J. F. Roche and M. G. Diskin. 1998. Effect of calf isolation on follicular wave dynamics, gonadotropin and metabolic hormone changes, and interval to first ovulation in beef cows fed either of two energy levels postpartum. Biol. Reprod. 59: 777-783.

225. Starbuck, M. J., E. K. Inskeep, and R. A. Dailey. 2006. Effect of a single growth hormone $(\mathrm{rbST})$ treatment at breeding on conception rates and pregnancy retention in dairy and beef cattle. Anim Reprod Sci 93:349-59.

226. Starbuck, M. J., R. A. Dailey, and E. K. Inskeep. 2004. Factors affecting retention of early pregnancy in dairy cattle. Anim Reprod Sci. 84(1-2):27-39. 
227. Stevenson, J. S., G. C. Lamb, D. P. Hoffman, and J. E. Minton. 1997. Interrelationships of lactation and postpartum anovulation in suckled and milked cows. Livest. Prod. Sci. 50:57-74.

228. Stevenson, J. S., M. K. Schmidt, and E. P. Call. 1983. Factors affecting reproductive performance of dairy cows first inseminated after five weeks postpartum. J. Dairy Sci. 66: 1148-1154.

229. Stevenson, S., E. L. Knoppel, J. E. Minton, B. E. Salfen, and H. A. Garverick. 1994. Estrus, ovulation, luteinizing hormone, and suckling-induced hormones in mastectomized cows with and without unrestricted presence of the calf. J. Anim. Sci. 72: 690-699.

230. Story, C. E., R. J. Rasby, R. T. Clark and C. T. Milton. 2000. Age of calf at weaning of spring-calving beef cows and the effect on cow and calf performance and production economics. J. Anim. Sci. 78: 1403-1413.

231. Sutovsky, P. 2003. Ubiquitin-dependent proteolysis in mammalian spermatogenesis, fertilization, and sperm quality control: killing three birds with one stone. Microsc. Res. Tech. 61(1):88-102.

232. Tennant, B., J. W. Kendrick, and R. G. Peddicord. 1967. Uterine involution and ovarian function in the post partum cow. A retrospective analysis of 2,338 genital organs examination. Cornell Vet. 57: 543.

233. Tennant, C. J., J. C. Spitzer, W. C. Bridges, Jr., and J. H. Hampton. 2002. Weight necessary to change body condition scores in Angus cows. J. Anim. Sci. 80: 2031-2035.

234. Tesseur, I., K. Zou, E. Berber, H. Zhang, and T. Wyss-Coray. 2006. Highly sensitive and specific bioassay for measuring bioactive TGF-beta. BMC Cell Biol. $7: 15-22$.

235. Thaler, C. J. 1989. Immunological role for seminal plasma in insemination and pregnancy. Am. J. Reprod. Immunol. 21:147-150.

236. Thatcher, W. W., C. R. Staples, G. Danet-Desnoyers, B. Oldick, and E. P. Schmitt. 1994. Embryo health and mortality in sheep and cattle. J. Anim. Sci. 72: 3-16(Suppl.).

237. Thérien, I., R. Moreau, and P. Manjunath. 1998. Major proteins of bovine seminal plasma and high-density lipoprotein induce cholesterol efflux from epididymal sperm. Biol. Reprod. 59:768-776.

238. Thérien, I., S. Soubeyrand, and P. Manjunath. 1997. Major proteins of bovine seminal plasma modulate sperm capacitation by high-density lipoprotein. Biol. Reprod. 57:1080-1088. 
239. Tortonese, D. J. and E. K. Inskeep. 1992. Effects of melatonin treatment on the attainment of puberty in heifers. J. Anim. Sci. 70: 2822-2827.

240. Tremellen, K. P., R. F. Seamark, and S. A. Robertson. 1998. Seminal transforming growth factor betal stimulates granulocyte-macrophage colonystimulating factor production and inflammatory cell recruitment in the murine uterus. Biol. Reprod. 58:1217-25.

241. Triplett, B. L., D. A. Neuendorff and R. D. Randel. 1995. Influence of undegraded intake protein supplementation on milk production, weight gain, and reproductive performance in postpartum Brahman cows. J. Anim. Sci. 73: 32233229.

242. VanDemark, N. L., and R. L. Hays. 1952. Uterine motility responses to mating. Am. J. Physiol. 170(3):518-21.

243. Vargas, C. A., T. A. Olson, C. C. Chase, Jr., A. C. Hammond, and M. A. Elzo. 1999. Influence of frame size and body condition score on performance of Brahman cattle. J. Anim. Sci. 77: 3140-3149.

244. Viker, S. D., R. L. Larson, G. H. Kiracofe, R. E. Stewart, and J. S. Stevenson. 1993. Prolonged postpartum anovulation in mastectomized cows requires tactile stimulation by the calf. J. Anim. Sci. 71: 999-1003.

245. Von Linsingen, R., E. P. Bompeixe, and Mda G. Bicalho. 2005. A case-control study in IL6 and TGFB1 gene polymorphisms and recurrent spontaneous abortion in southern Brazilian patients. Am. J. Reprod. Immunol. 53:94-9.

246. Wachenheim, C. J., and R. Singley. 1999. The beef industry in transition: Current status and strategic options. J. Agribusiness 17: 49-62.

247. Wagner, J. J. 1984. Carcass composition in mature Hereford cows: Estimation and influence on metabolizable energy requirements for maintenance during winter. Ph.D. dissertation, Oklahoma State Univ., Stillwater.

248. Wagner, J. J., K. S. Lusby, J. W. Oltjen, J. Rakestraw, R. P. Wettemann and L. E. Walters. 1988. Carcass composition in mature Hereford cows: estimation and effect on daily metabolizable energy requirement during winter. J. Anim. Sci. 66: 603-612.

249. Wagner, W. C., and W. Hansel. 1969. Reproductive physiology of the post partum cow. J. Reprod. Fertil. 18: 493-500.

250. Webb, R., G. E. Lamming, N. B. Haynes, and G. R. Foxcroft. 1980. Plasma progesterone and gonadotrophin concentrations and ovarian activity in postpartum dairy cows. J. Reprod. Fertil. 59: 133-143. 
251. Webb, S. M., A. W. Lewis, D. A. Neuendorff, and R. D. Randel. 2001. Effects of dietary rice bran, lasalocid, and sex of calf on postpartum reproduction in Brahman cows. J. Anim. Sci. 79: 2968-2974.

252. Wehrman, M. E., T. H. Welsh Jr., and G. L. Williams. 1991. Diet-induced hyperlipidemia in cattle modifies the intrafollicular cholesterol environment, modulates ovarian follicular dynamics, and hastens the onset of postpartum luteal activity. Biol. Reprod. 45: 451-458.

253. Weiner, H. L. 2001. Oral tolerance: immune mechanisms and the generation of Th3-type TGF $\beta$-secreting regulatory cells. Microbes Infect 3:947-954.

254. Werth, L. A., J. C. Whittier, S. M. Azzam, G. H. Deutscher, and J. E. Kinder. 1996. Relationship between circulating progesterone and conception at the first postpartum estrus in young primiparous beef cows. J. Anim. Sci. 74: 616-619.

255. Wettemann R. P. and I. Bossis. 2000. Nutritional regulation of ovarian function in beef cattle. J. Anim. Sci. Available: http://www.asas.org/jas/symposia/proceedings/0934.pdf. Accessed June 2005.

256. Wettemann, R. P. 1980. Postpartum endocrine function of cattle, sheep and swine. J. Anim. Sci. 51(Suppl. 2): 2-15. Review.

257. Wettemann, R. P., C. A. Lents, N. H. Ciccioli, F. J. White, and I. Rubio. 2003. Nutritional- and suckling-mediated anovulation in beef cows. J. Anim Sci. 81: E48-59.

258. Wettemann, R. P., G. M. Hill, M. E. Boyd, J. C. Spitzer, D.W. Forrest and W. E. Beal. 1986. Reproductive performance of post-partum beef cows after short-term calf separation and dietary energy and protein supplementation. Theriogenology 26: 433-443.

259. Wettemann, R. P., J. E. Turman and R. Totusek. 1978. Influence of suckling intensity on reproductive performance of range cows. J. Anim. Sci. 47: 342-346.

260. Whitman, R. W. 1975. Weight change, body condition and beef cow reproduction. Ph.D. dissertation, Colorado State Univ., Fort Collins.

261. Whittier, J. C., B. L. Weech, and R. Eakins. 1995. Effects of weaning calves from primiparous cows at the beginning of the breeding season following first calving on subsequent dam and calf productivity. J. Anim. Sci. 73: 241.

262. Wildeus, S., R. D. Randel, and W. D. Humphrey. 1987. Influence of repeated low doses of gonadotrop in releasing hormone on postpartum interval and serum luteinizing hormone in brahman cross cows. Theriogenology 27: 711-719.

263. Williams, G. L. 1989. Modulation of luteal activity in postpartum beef cows through changes in dietary lipid. J. Anim. Sci. 67: 785-793. 
264. Williams, G. L. 1990. Suckling as a regulator of postpartum rebreeding in cattle: review. J. Anim. Sci. 68: 831-852. Review.

265. Williams, G. L., R. G. Osborn, J. D. Kirsch and J. E. Tilton. 1984. Suckling, milking and calf presence as regulators of tonic gonadotropin release and postpartum interval. 10th Int. Congr. Anim . Reprod. Artif. Insem. Univ. of Illinois. Urbana-Champaign. p 410.

266. Wiltbank, J. N. 1970. Research needs in beef cattle reproduction. J. Anim. Sci. 31:755-762.

267. Wiltbank, J. N. and A. C. Cook. 1958. The comparative reproductive performance of nursed and milked cows. J. Anim. Sci. 17: 640-648.

268. Wiltbank, J. N., E. J. Warwick, E. H. Vernon, and B. M. Priode. 1961. Factors affecting net calf crop in beef cattle. J. Anim. Sci. 20: 409-415.

269. Wiltbank, J. N., W. W. Rowden, J. E. Ingalls and D. R. Zimmerman. 1964. Influence of post-partum energy levels on reproductive performance of Hereford cows restricted in energy intake prior to calving. J. Anim. Sci. 23: 1049.

270. Wiltbank, J. N., W. W. Rowden, J. E. Ingalls, K. E. Gregory, and R. M. Koch. 1962. Effect of energy level on reproductive phenomena of mature hereford cows. J. Anim. Sci. 21: 219-225.

271. Wiltbank, J. N., W. W. Rowden, J. E. Ingalls, K. E. Gregory, and R. M. Koch. 1962. Effect of energy level on reproductive phenomena of mature hereford cows. J. Anim. Sci. 21: 219.

272. Wiltbank, M. C., A. Gumen, and R. Sartori. 2002. Physiological classification of anovulatory conditions in cattle. Theriogenology 57: 21-52.

273. Wu, G., F. W. Bazer, J. M. Wallace, and T. E. Spencer. 2006. Board-invited review: Intrauterine growth retardation: Implications for the animal sciences. J. Anim. Sci. 84: 2316-2337.

274. Wu, T. F., and D. S. Chu. 2008. Sperm chromatin: fertile grounds for proteomic discovery of clinical tools. Mol Cell Proteomics. 7(10):1876-86.

275. Yavas, Y., and J. S. Walton. 2000. Induction of ovulation in postpartum suckled beef cows: A review. Theriogenology 54: 1-23.

276. Yu, B., Y. Zhao, W. F. Zhao, Chen, Y. Liu, J. Zhang, W. Fu, Z. Zong, A. Yu, and Y. Guan. 2003. The inhibitory effect of BSP-A1/-A2 on protein kinase $C$ and tyrosine protein kinase. Cell Biochem Funct 21:183-188. 
277. Zalesky, D. D., M. L. Day, M. Garcia-Winder, K. Imakawa, R. J. Kittok, M. J. D'Occhio, and J. E. Kinder. 1984. Influence of exposure to bulls on resumption of estrous cycles following parturition in beef cows. J. Anim. Sci. 59: 1135-1139.

278. Zollers, W. G., Jr., H. A. Garverick, and M. F. Smith. 1989. Oxytocin-induced release of prostaglandin $\mathrm{f} 2$ alpha in postpartum beef cows: Comparison of short versus normal luteal phases. Biol. Reprod. 41: 262-267.

279. Zollers, W. G., Jr., H. A. Garverick, M. F. Smith, R. J. Moffatt, B. E. Salfen, and R. S. Youngquist.1993. Concentrations of progesterone and oxytocin receptors in endometrium of postpartum cows expected to have a short or normal oestrous cycle. J. Reprod. Fertil. 97: 329-337.

280. Zollers, W. G., Jr., H. A. Garverick, R. S. Youngquist, J. S. Ottobre, R. W. Silcox, J. P. Copelin, and M. F. Smith. 1991. In vitro secretion of prostaglandins from endometrium of postpartum beef cows expected to have short or normal luteal phases. 1991. Biol. Reprod. 44: 522-526. 